LILIANA CARRARD

O PrincíPio da Insignificância E a Mínima Intervenção Penal

DisSERTAÇÃO DE MESTRADO

Orientadora: Mariângela Gama de Magalhães Gomes

FACULDADE DE DIREITO - USP

São Paulo - 2013 


\section{O PRINCÍPIO DA INSIGNIFICÂNCIA E A Mínima Inter VenÇÃo Penal}

Trabalho apresentado perante o Departamento de Direito Penal, Criminologia e Medicina Forense da Faculdade de Direito da USP como requisito parcial para a obtenção do título de Mestre, sob orientação da Professora Doutora Mariângela Gama de Magalhães Gomes.

\section{São PaUlo}

2013 
FOLHA DE APROVAÇÃO

LILIANA CARRARD

\section{O Princípio da Insignificância e a Mínima Intervenção Penal}

Dissertação apresentada à Faculdade de Direito para obtenção do título de Mestre

Área de concentração: Direito penal

Aprovada em:

\section{Banca Examinadora}

Prof. (a) Dr. (a)

Instituição:

Prof. (a) Dr. (a)

Instituição:

Prof. (a) Dr.(a)

Instituição: 
Aos meus pais Arno e Liane, pessoas muito especiais, por tudo que representam para mim. Meu sincero agradecimento, por tudo.

Aos meus irmãos (e melhores amigos) Angélica, Rafael e Bianca, e cunhados Nórton, Adriane e Tiago, por toda a parceria e amizade verdadeira que sabemos cultivar. Às pequenas Clara, Catarina e Liz, e minha afilhada Olívia, verdadeiros anjinhos em nossas vidas, pela imensa alegria que representam.

Ao meu amado Luciano, que esteve comigo nesta caminhada e que me faz viver o amor todos os dias da nossa vida. 


\section{Agradecimentos}

A realização do presente trabalho só foi possível porque contou com a competente orientação da $\operatorname{Prof}^{a}$ Dr $^{a}$ Mariângela Gama de Magalhães Gomes, com quem muito aprendi. Agradeço imensamente pela altíssima qualidade de ensino e pelo senso de responsabilidade que envolveu a orientação.

Agradeço também aos colegas do Mestrado que seguiram comigo ao longo desta jornada, em especial ao Renato Silvestre Marinho e Marina Zanotello. 


\section{RESUMO}

CARRARD, Liliana. O Princípio da Insignificância e a mínima intervenção penal. São Paulo, 2013. Dissertação. Universidade de São Paulo, Faculdade de Direito do Largo de São Francisco.

O presente trabalho se dedica a estudar o surgimento e critérios de aplicação que envolvem a incidência do princípio da insignificância. Serão analisados, para tanto, os conceitos do chamado direito penal de mínima intervenção, que prega o respeito à ultima ratio do Direito Penal. Demonstra, desta forma, que a Constituição vigente, ainda que não refira expressamente o principio da insignificância, o legitima por meio dos demais princípios. Demonstra, ainda, que a aplicação do princípio está em consonância com os preceitos de uma intervenção penal minimamente necessária.

Palavras-Chave: Direito Penal Mínimo. Intervenção penal mínima. Ultima ratio. Princípio da subsidiariedade. Bem jurídico-penal. Princípio da insignificância. Direito Penal do Autor. 


\begin{abstract}
CARRARD, Liliana. The principle of insignificance and the minimum criminal intervention.

The present work aims to study the emergence and criteria for applying the principle of insignificance. Therefore, will be analyzed the concepts of criminal law called minimal intervention, which advocates respect for the ultima ratio of the Criminal Law. Thus, demonstrates that the current Constitution, though not explicitly refer to the principle of insignificance, legitimized it through the principles of others. It also demonstrates that the principle is in line with the precepts of a criminal intervention minimally required.
\end{abstract}

Keywords: Minimum Criminal Law. Criminal minimal intervention. Ultima ratio. Principle of subsidiarity. Well-criminal legal. Principle of insignificance. Criminal Law Author. 


\section{SUMÁRIO}

INTRODUÇÃO

\section{Capítulo 1. O Direito Penal de mínima intervenÇão}

1.1. Diretrizes básicas do Direito Penal Mínimo 12

1.2. O princípio da intervenção mínima 16

1.3. O conceito de ultima ratio 19

1.4. A natureza subsidiária do Direito Penal 22

1.4.1. A autonomia do Direito Penal Subsidiário 25

1.5. O Direito Penal Mínimo e a subordinação ao texto constitucional 26

1.5.1. O poder limitador da Constituição no Direito Penal 27

\section{CAPÍtUlo 2. O BEM JURÍdico-PENAL}

2.1. Noções conceituais: bem jurídico como fundamento da incriminação 29

2.2. A influência social na escolha dos bens jurídicos a serem penalmente tutelados 33

2.3. Bens jurídico-penais e sua relação com a Constituição 36

2.3.1. Menção direta ou indireta, no texto constitucional, aos bens que devem ser juridicamente tutelados

\section{CAPÍtUlo 3. O PRINCÍPIO DA INSIGNIFICÂNCIA}

3.1. Conceito de princípio da insignificância 41

3.2. Origem histórica $\quad 44$

3.3. Da legitimação constitucional do princípio $\quad 46$

3.4. O princípio da insignificância como via redutora da repressão penal 47

3.5. Critérios de aplicação do princípio da insignificância 49

3.5.1. Surgimento dos critérios de aplicação na jurisprudência 49

3.5.2. O valor monetário como critério de aplicação do princípio 56

2.1. O princípio da oportunidade: o interesse estatal na propositura da penal e a insignificância 


\section{CAPÍTUlO 4. CONSEQUÊNCIAS DO RECONHECIMENTO DO PRINCÍPIO DA INSIGNIFICÂNCIA}

4.1. Excludente de ilicitude $\quad 64$

4.1.1. Crítica: fragilidades 66

4.2. Excludente de culpabilidade $\quad 68$

4.2.1. Crítica: a supremacia do direito penal do autor $\quad 70$

$\begin{array}{ll}\text { 4.3. Excludente de tipicidade } & 73\end{array}$

4.3.1. As condutas típicas de menor potencial ofensivo e a compatibilidade com o princípio da insignificância $\quad 82$

CAPÍTULO 5. PROBLEMÁTICA NA APLICAÇÃo dO PRINCÍPIO DA INSIGNIFICÂNCIA 88

5.1. A reiteração de condutas insignificantes de mesma natureza: a continuidade 89

5.2. A reiteração de diferentes condutas insignificantes: os antecedentes bagatelares 92

5.3. Fato insignificante cometido por um indivíduo reincidente 96

5.3.1. Crítica: a reincidência como óbice ao reconhecimento da insignificância $\quad 97$

5.3.1.1. A incompatibilidade do direito penal do autor com o Direito Penal Mínimo 98

5.4. A habitualidade: os crimes de massa 102

5.5. A aplicação nos crimes violentos ou com grave ameaça 105

5.6. A aplicação nos crimes complexos 107

$\begin{array}{ll}\text { NOTAS CONCLUSIVAS } & 110\end{array}$

REFERÊNCIAS BIBLIOGRÁFICAS 


\section{INTRODUÇÃO}

O Direito Penal é a esfera jurídica que se caracteriza pela força de suas ações, decisões e efeitos.

Por mais brando que tente ser o Direito Penal - aplicando substituições de penas, estabelecendo procedimentos em leis especiais como a Lei $n^{\circ}$ 9.099/95 - fato é que sua atuação sempre possui forte efeito.

O princípio da insignificância, cuja atuação na esfera penal é relativamente recente

no Brasil, não está previsto nem na Carta Maior, tampouco na legislação ordinária. É, entretanto, utilizado para declarar determinadas condutas insignificantes ao Direito Penal.

Com isso, atua de forma a legitimar a máxima de que o Direito Penal só deve se preocupar com as condutas que efetivamente causem alguma lesão ao bem jurídico penalmente tutelado.

Este princípio é o ponto central de estudo do presente trabalho.

No primeiro capítulo, serão estudadas as diretrizes do Direito Penal de mínima intervenção, o conceito do que vem a ser a ultima ratio e o caráter subsidiário do Direito Penal. A relação desta área jurídica com o texto constitucional também será abordada.

A intenção é demonstrar que a esfera penal é a via jurídica mais radical, como já dito, e para ela devem ser dedicadas apenas as condutas cuja análise e julgamento não podem ser realizados em outras áreas do Direito.

O segundo capítulo será dedicado ao estudo sobre os bens jurídicos, mais especialmente os bens penalmente protegidos. O estudo, ainda que não esgote a matéria, focará no papel do bem jurídico como elemento de incriminação no Direito Penal.

Será abordada a forma de criação e escolha dos bens protegidos na esfera penal e, ainda, a relação desta escolha com a Constituição.

No terceiro capítulo, será iniciado o estudo do Princípio da Insignificância. Sua origem será demonstrada, bem como seus critérios de aplicação.

Muito se discute acerca da aplicação do princípio nos crimes ambientais, nos crimes contra a administração pública, entre tantos outros. Preferiu-se não focar nesta 
abordagem específica acerca de determinados tipos penais, muito embora alguns deles tenham sido citados, ou a título de exemplo, ou nos julgados mencionados.

O quarto capítulo falará sobre as consequências geradas com o reconhecimento do princípio. Serão apresentadas as três possibilidades de consequência: excludente de tipicidade (defendida no presente trabalho), excludente de ilicitude e, ainda, excludente de culpabilidade.

O quinto e último capítulo tratará de pontos polêmicos no que toca à aplicação do princípio da insignificância. Serão abordadas as problemáticas que envolvem o reconhecimento do principio em casos cujo agente da conduta é reincidente, possui antecedentes ou acumula em seu histórico um rol de condutas bagatelares.

Dentro deste mesmo capítulo, serão abordadas questões como crimes violentos ou com grave ameaça, crimes complexos e a problemática da valoração do dano sem, contudo, estudar-se a aplicação do princípio especificamente em relação a determinados tipos penais.

Este estudo terá direta relação com o tópico anterior que, ao tratar da excludente de culpabilidade, relaciona-a a um modelo que é incompatível com o Direito Penal de mínima intervenção.

Muito embora haja um tópico específico abordando o surgimento da aplicação do princípio da insignificância na jurisprudência pátria, o presente trabalho não possui a intenção de, a cada item apresentado, demonstrar qual o entendimento jurisprudencial existente.

O estudo não tem a finalidade de demonstrar detalhadamente os diferentes entendimentos dos tribunais acerca de cada um dos temas abordados. Quando mencionado algum julgado, é porque foi considerado pertinente. Por não ser a jurisprudência o foco do estudo, não está presente em todas as matérias ventiladas. 


\section{Capítulo 1. O Direito Penal de mínima intervenção}

\subsection{Diretrizes báSicas do Direito Penal Mínimo}

As formas de sociedade até hoje estudadas pela História, relatam a existência de alguma espécie de punição aplicada entre seus membros. Estas manifestações tão antigas de atuação não necessariamente eram codificadas. Ademais, mesmo naquelas sociedades ainda dissociadas da ideia de um Estado atuante, já existia a punição e aplicação de penalidades.

Esta assertiva demonstra que, ao que tudo indica, enquanto houver sociedade, haverá condutas que serão entendidas por ela como delitos e, como consequência, sempre haverá intenção de puni-los.

O modelo de Direito Penal Mínimo não duvida da existência desta constatação, tampouco a rejeita. Não possui a pretensão de oferecer um remédio definitivo para a existência de delitos dentro das sociedades. Entende que tais condutas são inerentes à existência das sociedades.

O Direito Penal Mínimo é um modelo que se sustenta entre dois extremos, quais sejam, o Abolicionismo Penal e o Direito Penal Máximo. ${ }^{1}$ Rejeita o modelo de total inércia estatal frente a determinadas condutas sociais; rejeita, igualmente, o modelo de extrema atuação estatal, com utilização dos mais contundentes mecanismos que dispõe a via penal; não possui, portanto, a intenção de tutelar toda e qualquer conduta que gere uma mínima ofensa a qualquer bem jurídico.

Como se vê, este modelo de Direito Penal Mínimo prega o ideal de intervenção penal no seu grau mínimo (ou minimamente necessário), porque entende que a atuação penal estatal traz, sempre e inevitavelmente, prejuízos ao cidadão e à sociedade. " $O$ direito penal não é só a mais violenta forma de intervenção do Estado na vida dos cidadãos, mas é também, seguramente - e talvez por isso mesmo - a mais desastrosa forma de intervenção do Estado na vida social".2

\footnotetext{
${ }^{1}$ CARVALHO, Salo. Pena e Garantias. RJ: Lumen Juris, 2003, p. 84.

${ }^{2}$ QUEIROZ, Paulo de Souza. Do caráter subsidiário do Direito Penal: lineamentos para um Direito Penal Mínimo. Belo Horizonte: Del Rey, 1998, p.31.
} 
De forma alguma o Direito Penal Mínimo é permissivo com a prática de crimes. ${ }^{3} \mathrm{E}$, como se verá adiante, a aplicação do Princípio da Insignificância não é vista como ato de permissão à prática de condutas delitivas que possuam ofensa ínfima ao bem jurídico.

É que os olhos deste modelo estão voltados para a Constituição. As diretrizes estão pautadas, primordialmente, no respeito aos princípios constitucionais.

É, aliás, na própria Carta Maior que o Direito Penal encontra legitimidade: “ $O$ Direito Penal jamais sobreviveria se não tivesse um forte substrato constitucional, porque é na Constituição que vem auferir legitimidade para interferir em direitos fundamentais dos cidadãos (...).".4

O ideal alcançado se traduz no máximo zelo tanto aos princípios constitucionais penais (como o princípio da proporcionalidade, princípio da taxatividade) quanto aos princípios constitucionais processuais (como presunção de inocência, contraditório, ampla defesa e todos os demais que compõem o devido processo legal).

FERRAJOLI, ao contrapor o Direito Penal Mínimo com o modelo de Direito Penal Máximo, refere que se no mais rigoroso dos dois modelos, nenhum cidadão passa despercebido pelo sistema investigatório e punitivo estatal,

a certeza perseguida pelo direito penal mínimo é, ao contrário, que nenhum inocente seja punido à custa da incerteza de que algum culpado reste impune. Os dois tipos de certeza, e os custos ligados às respectivas incertezas, refletem interesses e opções políticas contrapostas: de um lado a máxima tutela da segurança pública contra as ofensas ocasionadas pelos crimes, por outro, a máxima tutela das liberdades individuais contra as ofensas geradas por penas arbitrárias. ${ }^{5}$

Para o programa político-criminal do Direito Penal Mínimo, a meta é maximizar os direitos dos cidadãos e, em contrapartida, reduzir o impacto que a via penal exerce na sociedade, o que inclui, fatalmente, a intenção de redução das massas carcerárias (em face

\footnotetext{
${ }^{3}$ FERNANDES, Luciana de Medeiros. Direito Penal Máximo ou intervenção mínima do Direito Penal? Breves lineamentos sobre a função do Direito Penal. Revista Brasileira de Ciências Criminais $\mathrm{n}^{\circ} 69$. Nov.dez. 2007, p. 83.

${ }^{4}$ BENETI, Sidnei Agostinho. A Constituição e o sistema penal. Revista Ajuris, Porto Alegre: Ajuris n. 156, 1992, p. 155.

${ }^{5}$ FERRAJOLI, Luigi. Derecho y razón. Madrid: Trotta, 2006, p. 83.
} 
de um maior controle, restritivo, do número de prisões decretadas e do número de condenações ao cárcere). ${ }^{6}$

FERRAJOLI defende a aplicação minimamente necessária do Direito Penal, apenas no limite mínimo necessário e em proporção ao que pede o princípio da ofensividade. Trata-se, conforme FERRAJOLI propõe, de aplicar o quanto necessário (sem excessos) para a proteção dos bens jurídicos fundamentais. ${ }^{7}$

Se por um lado pode-se verificar que um os lemas do Direito Penal Máximo é produzir uma verdadeira campanha de "caça às bruxas" - com flagrante cerceamento das garantias individuais para atingir tal fim - por outro se constata que o Direito Penal Mínimo não permite que o Estado adote postura de negação aos direitos fundamentais, e a ele não concede poder irrestrito para a punição penal. ${ }^{8}$

E falar em Direito Penal Mínimo não equivale a defender o "permissivismo”, e sim respeitar os direitos de humanidade, inserindo-os na ordem jurídica vigente. ${ }^{9}$

Se para o Direito Penal Máximo a aplicação de penas severas é a regra, no Direito Penal Mínimo a pena não é a maior fonte de atenção, já que não é ela que garante o cuidado aos bens penalmente tutelados. A pena, por ser aplicada somente depois (ex post) de ofendido o bem, não tem o mesmo poder de caráter protetivo.

Por esta razão as normas (que atuam antes da prática das condutas, já existindo no momento em que estas são praticadas) têm a capacidade de efetivamente zelar pelos bens jurídicos. ${ }^{10}$

A atuação penal exercida pelo Estado somente se justifica, no Direito Penal Mínimo, se os conflitos existentes não puderem ser resolvidos dentro do seu próprio âmbito (dentro da própria família, por exemplo; ou entre os próprios envolvidos; ou, ainda, dentro da própria comunidade).

E, uma vez que não resolvidos dentro do seu próprio âmbito social e então já inseridos no mundo jurídico, a via penal deve ser utilizada somente quando tais conflitos não puderem ser solucionados pelas outras vias do Direito. ${ }^{11}$

\footnotetext{
${ }^{6}$ CARVALHO, Salo. Pena e Garantias, cit., p. 88.

${ }^{7}$ FERRAJOLI, Luigi. Derecho y razón, cit., p. 84.

${ }^{8}$ FERNANDES, Luciana de Medeiros. Direito Penal Máximo ou intervenção mínima do Direito Penal? Breves lineamentos sobre a função do Direito Penal, cit., p. 83.

${ }^{9}$ Idem, ibidem.

${ }^{10}$ GRACIA MARTIN, Luis. Fundamentos de dogmática penal: una introducción a la concepción finalista de la responsabilidad penal. Barcelona: Atelier, 2006, p. 168-169.
} 
Este modelo penal entende, portanto, que a atuação penal exercida pelo Estado sempre trará algum prejuízo aos indivíduos diretamente atingidos por tal atuação e, ademais, a toda a sociedade.

Os efeitos nocivos do Direito Penal são inevitáveis, daí porque a razão de aplicá-lo o mínimo possível. "Reduzir, pois, tanto quanto seja possível, o marco de intervenção do sistema penal, é uma exigência de racionalidade."12

O Direito Penal Mínimo constata que a estrutura social moderna tem sido cada vez mais moldada de forma a se conseguir organizá-la e controlá-la.

Resultado disso é que tudo que possa vir a ser considerado interesse público, acaba gerando uma nova criação legal. Tudo, absolutamente tudo, passa a ser tutelado pela legislação. Diante desta realidade, o Estado utiliza também o Direito Penal para manter o controle (poder) social. ${ }^{13}$

O problema reside exatamente neste modelo exagerado de controle. A regra passa a ser uma verdadeira inflação legislativa em todos os ramos do Direito, como o Administrativo e o Civil.

Ocorre, no entanto, que este crescente incremento de regras gera um consequente incremento de novas previsões penais, que surgem para atuar quando tais regras forem descumpridas. Esta realidade está em dissonância com o que seria mais lógico: proceder com prudência na criação de regras gerais e, somente nos casos mais graves de ofensa às mesmas é que deveria ser aplicada a via penal. ${ }^{14}$

O resultado final almejado pelo Direito Penal é de suma relevância para que se perceba o papel do Direito Penal Mínimo. Não há razão para que o Estado aplique medidas de caráter mais forte e com carga punitiva mais alta, se tem a possibilidade de aplicar sanções de natureza menos gravosa, com resultado final idêntico. ${ }^{15}$

Significa dizer que, por mais paradoxal que possa parecer, o Direito Penal — quando aplicado com forte carga punitiva - não logra êxito em atingir um resultado mais

\footnotetext{
${ }^{11}$ QUEIROZ, Paulo de Souza. Do caráter subsidiário do Direito Penal: lineamentos para um Direito Penal Mínimo, cit., p. 79.

${ }^{12}$ Idem, ibidem, p.31.

13 MAURACH, Reinhart. Derecho Penal. Parte general. Atualizado por Heinz Zipf. Buenos Aires: Delpalma, 1994, p.35.

${ }^{14}$ Idem, ibidem.

${ }^{15}$ Idem, ibidem, p.34.
} 
eficaz. Tal resultado pode ser conquistado com aplicação de medidas penais menos agressivas, que possuem menos efeitos colaterais.

E este resultado final pode ser alcançado se o Direito Penal exercer o poder de autolimitação: deve limitar sua própria atuação e, quando o fizer, deve limitar a carga de punição que aplicar, "adoçando a aspereza das suas sanções". ${ }^{16}$

ROXIN observa que o Direito Penal não deve ser utilizado em situações onde a restauração da ordem jurídica pode ser feita por meio de procedimentos mais amenos. Em tais situações, se utilizado o Direito Penal, produz-se efeitos muito mais nocivos para a própria paz jurídica, com flagrante distorção do que seria o verdadeiro objetivo da norma. ${ }^{17}$

Quando a sociedade pode ser protegida por outros meios que não a esfera penal — meios estes que sejam evidentemente menos lesivos aos direitos individuais - é porque o Direito Penal não é essencial e não deve, portanto, ser invocado. Esta é a essência teórica do Direito Penal Mínimo. A finalidade que possui deriva desta regra de mínima intervenção. ${ }^{18}$

\subsection{O PRINCÍPIO dA INTERVENÇão MínIMA}

O surgimento deste princípio ocorreu com o crescimento do movimento burguês e a força do seu clamor pelo fim do sistema penal absolutista, no final do século XVIII.

A classe burguesa mostrava-se claramente insatisfeita com os antagonismos entre o regime político absolutista e o sistema capitalista que vinha surgindo. ${ }^{19}$

Em uma época em que penas cruéis eram a regra (a tortura, por exemplo, era recurso utilizado de forma ordinária, e absolutamente permitida), as idéias iluministas tornaram o pensamento crítico liberal o maior inimigo dos modelos do Antigo Regime. ${ }^{20}$

\footnotetext{
${ }^{16}$ MARINUCCI, Giorgio; DOLCINI, Emilio. Diritto Penale 'Minimo' e nuove forme di Criminalitá. Rivista Italiana di Diritto e Procedura Penale, Milano: Dott. A. Giufffre Editore, set. 1999, p. 819.

${ }^{17}$ ROXIN, Claus. Iniciación al derecho penal de hoy. Sevilla: Ediciones Universidad de Sevilla, 1981, p. 31.

${ }^{18}$ MIR PUIG, Santiago. Derecho Penal. Parte General. 7. ed. Barcelona: Reppertor, 2006, p.126.

${ }^{19}$ BATISTA, Nilo. Introdução Crítica ao Direito Penal, cit., p. 84.

${ }^{20}$ ROBERTI, Maura. A intervenção mínima como princípio no Direito Penal Brasileiro. Fabris: Porto Alegre, 2001, p. 65.
} 
O fato é que se deve a CESARE BECCARIA o maior crédito de ter dado alarmante publicidade, em seu livro Dos Delitos e das Penas (lançado em 1764), à necessidade de o Estado respeitar os direitos e garantias dos cidadãos submetidos a processo penal. ${ }^{21}$

BECCARIA foi, sem dúvida, o marco teórico referencial que separou o então modelo intervencionista e agressor exercido na época, de um modelo pautado pelo respeito aos direitos humanos.

De forma pioneira, clama que a finalidade da pena é ser suficientemente forte para atingir seu fim, sem desconsiderar, entretanto, a proporcionalidade entre a gravidade do crime e a intensidade da reprimenda. ${ }^{22}$ Ainda, reclama que a pena não pode ser instrumento de paixão de poucas minorias, ou, ainda, acaso de um determinado momento. ${ }^{23}$

Como se vê, os ideais beccarianos traduzem exatamente os preceitos de um modelo minimamente intervencionista, o que dá a BECCARIA o título de precursor do princípio da intervenção mínima.

A intervenção mínima é a ferramenta principiológica utilizada no Direito Penal Mínimo. Este último é a 'máquina' que se movimenta por meio de vários instrumentos, sendo o principal deles o princípio da intervenção mínima.

Tal princípio pode ser explicado por meio da missão que possui: a proteção dos bens juridicamente relevantes que estejam no topo da escala de importância. A intervenção mínima da via penal se traduz na atuação desta apenas quando se tratar situações com comprovada necessidade. ${ }^{24}$

Não há previsão constitucional expressa de tal princípio; ele não está, tampouco, taxativamente previsto (com roupagem de norma) no Código Penal.

No entanto, a falta de menção expressa no texto da Constituição ou, ainda, no texto legal, em nada impede que seja imposto ao legislador e ao intérprete da lei, tendo em vista que possui evidente compatibilidade e sintonia com outros princípios jurídico-legais devidamente expressos. ${ }^{25}$

\footnotetext{
${ }^{21}$ Idem, ibidem, p.66.

${ }^{22}$ BECCARIA, Cesare. Dos delitos e das penas. SP: Martin Claret, 2000, p. 49.

${ }^{23}$ Idem, ibidem, p. 15.

${ }^{24}$ GOMES, Mariângela Gama de Magalhães. O princípio da proporcionalidade no Direito Penal brasileiro. São Paulo: RT, 2003, p.85.

${ }^{25}$ BATISTA, Nilo. Introdução Crítica ao Direito Penal, cit., p. 85.
} 
Em alguns textos constitucionais, a menção à intervenção mínima do Direito Penal está prevista de forma expressa. O artigo 19 da Constituição da Argentina prevê a proibição de tipificação de condutas que não venham a ferir minimamente o bem juridicamente tutelado, regra esta igualmente contida no artigo 49 da Constituição paraguaia. ${ }^{26}$

O princípio da intervenção mínima se traduz na atuação estatal somente quando a medida penal se mostrar necessária para a manutenção da organização política dentro do que se entende por Estado Democrático e Social de Direito. ${ }^{27}$

O direito penal só deve intervir nos casos de ataques muito graves aos bens jurídicos mais importantes, e as perturbações mais leves da ordem jurídica são objeto de outros ramos do direito. ${ }^{28}$

Recebendo de LUISI o nome de princípio da necessidade, é explicado pelo doutrinador como o maior orientador e limitador da criação e aplicação das mazelas penais. $^{29}$

É por meio deste princípio que se busca a proporcionalidade entre a conduta tida por delituosa e a resposta estatal, que não pode ser mais gravosa do que o mal cometido.

PALAZZO demonstra esta dualidade:

Se de um lado a ação delituosa constitui, de fato, ao menos como regra, o mais grave ataque que o individuo desfere contra os bens sociais máximos tutelados pelo Estado, por outro lado a sanção criminal também, por natureza, dá corpo à mais aguda e penetrante intervenção do Estado na esfera individual. ${ }^{30}$

Pode-se dizer que o princípio da intervenção mínima possui, no ordenamento jurídico-penal, três finalidades que dão suporte aos pilares do Direito Penal Mínimo.

A primeira finalidade consiste na influência direta às hipóteses de incidência da lei penal. Esta função está diretamente relacionada ao trabalho do legislador de tipificação de

\footnotetext{
${ }^{26}$ ZAFFARONI, Raul Eugenio. Sistemas penales e derechos humanos em America Latina. Buenos Aires: Dapalma, 1986, p. 26.

${ }^{27}$ BUSTOS RAMIREZ, Juan. Manual de Derecho Penal, parte general. $3^{\mathrm{a}}$ ed. Ariel: Barcelona, 1989, p. 44.

${ }^{28}$ MUÑOZ CONDE, Francisco. Introducción al Derecho Penal. Barcelona: Bosch, p.59.

${ }^{29}$ LUISI, Luiz. Os Princípios Constitucionais Penais. Porto Alegre: Fabris, 1991, p. 83.

${ }^{30}$ PALAZZO, Francesco Carlo. Valores constitucionais do direito penal. Porto Alegre: Fabris, 1989, p. 16.
} 
condutas e, após, de cominação das penas abstratas. Como se vê, é evidente a relação, aqui, com o princípio da proporcionalidade. ${ }^{31}$

A segunda finalidade conferida ao princípio da intervenção mínima está diretamente relacionada à constatação acerca da real possibilidade de considerar determinada conduta típica.

Conforme se verá mais adiante, nem toda conduta formalmente típica é materialmente típica. Cabe, portanto, a este princípio, auxiliar na tarefa de afastar da esfera punitiva penal as condutas que não possuam tipicidade material. ${ }^{32}$

Por último, pode-se indicar que a terceira finalidade do princípio é a minimização das consequências jurídicas que surgem quando reconhecido o cometimento de um delito. ${ }^{33}$

Esta finalidade se traduz, assim, no esforço em tentar reduzir ao máximo os efeitos nocivos que as penas (em especial as modalidades de penas privativas de liberdade) causam nos cidadãos por ela atingidos.

Penas alternativas à prisão, bem como aplicação da reprimenda em um patamar temporal mínimo, são alguns exemplos dos esforços estabelecidos pelo principio da intervenção mínima.

\subsection{O CONCEITO DE Ultima RATIO}

A ultima ratio do Direito Penal se traduz em afirmar que este ramo do Direito ocupa o último lugar na escala dos mecanismos jurídicos utilizados; se traduz em afirmar, ainda, que no rol dos meios estatais de poder, está a esfera penal no final da lista, sendo utilizada somente quando realmente indispensável para a conservação da paz social. ${ }^{\mathbf{3 4}}$

O legislador deve fazer um uso moderado e prudente dos mecanismos penais, tudo em conformidade com o princípio da proporcionalidade, entendendo que tais mecanismos devem atender à exigência de ultima ratio da esfera penal. ${ }^{35}$

\footnotetext{
${ }^{31}$ ROBERTI, Maura. A intervenção mínima como princípio no Direito Penal Brasileiro, cit., p.73.

${ }^{32}$ LOPES, Mauricio Antônio Ribeiro. Alternativas para o direito penal e o princípio da intervenção mínima. Revista dos Tribunais, Fascículos Penais, ano 87, v. 757, p. 402-411, nov/1998. p.40.

${ }^{33}$ ROBERTI, Maura. A intervenção mínima como princípio no Direito Penal Brasileiro, cit., p.93.

${ }^{34}$ MAURACH, Reinhart. Derecho Penal. Parte general, cit., p.34.

${ }^{35}$ Idem, ibidem, p.36.
} 
A natureza de ultima ratio do Direito Penal é bem definida com o conceito de que este ramo do Direito é "a artilharia pesada do Estado destinada ao resguardo derradeiro desses bens fundamentais". 36

A concepção de pena é, também, de ultima ratio, por ser ela uma solução imperfeita. ${ }^{37}$ Pode ser chamada de solução imperfeita porque, muito embora adotada pela legislação penal, inequívoca é a consciência de que se traduz em medida ineficaz ao que se pretende: prevenção de novos crimes.

Ao tratar sobre a ultima ratio, explicando-a como a razão para que tanto as penas como as medidas de segurança não sejam aplicadas com prioridade pelo Direito, MIR PUIG declara que "el principio rector debe ser que no está justificado un recurso más grave cuando cabe esperar los mismos o mejores resultados de otros más suaves." 38

Pois bem. O modelo de Estado Democrático de Direito não poderia se distanciar, por certo, do caráter de ultima ratio do Direito Penal. Isto porque o texto constitucional é longo no que tange a direitos e garantias constitucionais.

Por conseguinte, não seria legítimo que apresentasse previsão constitucional tão significativa em favor dos cidadãos, para ao mesmo tempo permitir que a via estatal penal incida sobre estes mesmos jurisdicionados e cerceie muitos desses direitos e garantias. ${ }^{39}$

É que a Constituição declara a proteção à dignidade da pessoa humana, a promoção do bem a todos (sem qualquer discriminação), a constituição de sociedade livre e justa, bem como o direito de ir e vir e o direito a livre manifestação de ideias, entre tantos outros.

O que o Direito Penal Mínimo entende é que não poderia este mesmo Estado Democrático de Direito (que criou todas estas previsões constitucionais) aplicar, na esfera penal, um sistema institucional de violência extrema, que logicamente fere todos estes direitos e garantias. $^{40}$

GARCÍA-PABLOS DE MOLINA se refere à ultima ratio do Direito Penal como a forma menos agressiva de solucionar um conflito, nos casos em que um 'tratamento cirúrgico' deve ser aplicado. Ressalta que em casos de menor gravidade, o Direito Penal

\footnotetext{
${ }^{36}$ QUEIROZ, Paulo de Souza. Do caráter subsidiário do Direito Penal, cit., p.33.

${ }^{37}$ BATISTA, Nilo. Introdução Crítica ao Direito Penal, cit., p. 85.

${ }^{38}$ MIR PUIG, Santiago. Introducción a las bases del Derecho Penal. Concepto y método. Barcelona: Bosch, 1976, p. 125.

${ }^{39}$ QUEIROZ, Paulo de Souza. Do caráter subsidiário do Direito Penal, cit., p.31.

${ }^{40}$ Idem, ibidem.
} 
deve se manter distante, já que podem ser tratados com mecanismos socialmente menos nocivos do que a máquina penal. ${ }^{41}$

E BARBERÁ alerta para o fato de que o próprio Direito já deve ser entendido como um recurso último na solução dos conflitos: deve atuar e incidir nas relações sociais somente se, conforme já mencionado, as partes envolvidas não forem capazes de, por si só, solucionar tais impasses. Por consequência, se o Direito já é tido como ultima ratio, o Direito Penal ainda mais o é. ${ }^{42}$

BARATTA advoga no sentido de que devem ser penalmente tutelados apenas os delitos que impedem a realização dos objetivos constitucionais do Estado (leia-se delitos que venham a incrementar a injustiça social e os de natureza verdadeiramente grave, amparados pelos princípios da lesividade ou necessidade), afastando os demais que podem ser discutidos em esferas alienígenas ao Direito Penal (entenda-se, aqui, novamente, o Direito Penal como ultima ratio). ${ }^{43}$

A mão severa da via penal (seja em fase pré-processual ou processual, seja quando dosada a pena propriamente) deve ser aplicada somente na mais extrema situação. Do contrário, outras áreas alienígenas à esfera penal podem ser acionadas. O que importa dizer é que as condutas que não atinjam minimamente o bem jurídico não justificam nem processo penal, nem pena. ${ }^{44}$

Até porque se se legitimasse o uso do Direito Penal para a solução de todos os conflitos, estar-se-ia diante de uma permanente e violenta atuação estatal. Estar-se-ia legitimando que o Estado - com a justificativa de evitar e conter a violência - pudesse atuar de forma igualmente violenta. O uso indiscriminado do Direito Penal causaria este cenário: a submissão dos cidadãos ao uso da força violenta pelo Estado punitivo. ${ }^{45}$

BUSTOS RAMIREZ ressalta que se o Estado se convertesse realmente em um Estado policial, com uso exagerado dos meios penais, toda a atividade social correria o risco de estar paralisada. ${ }^{46}$ A consequência seria o surgimento de uma insegurança social

\footnotetext{
${ }^{41}$ GARCIA-PABLOS DE MOLINA, Antônio. Derecho Penal. Madrid, 1984, p.5.

${ }^{42}$ BARBERÁ, Gabriel Perez. Teoria Social de Sistemas y Derecho Penal de Minima Intervención. Revista de Derecho Penal, Buenos Aires, p. 133.

${ }^{43}$ BARATTA, Alessandro. Criminologia Crítica e Crítica ao Direito Penal. $2^{\mathrm{a}}$ ed. Rio de Janeiro: Freitas Bastos, 1999.

${ }^{44}$ FERRAJOLI, Luigi. Derecho e razón, cit., p. 477.

${ }^{45}$ QUEIROZ, Paulo de Souza. Do caráter subsidiário do Direito Penal, cit., p.83.

${ }^{46}$ BUSTOS RAMIREZ, Juan. Manual de Derecho Penal, parte general, cit., p. 44.
} 
generalizada. ${ }^{47}$ Os cidadãos não mais veriam o Estado como protetor; pelo contrário, se sentiriam desprotegidos e, ainda pior, desamparados e desrespeitados.

Além do mencionado prejuízo à sociedade com um todo, pode-se igualmente concluir que o uso impróprio da máquina penal causa prejuízo individual ao cidadão diretamente atingido por ela. A submissão de um indivíduo às vias penais - especialmente se ao final lhe for aplicada pena - pode determinar sua exclusão do mundo social, estigmatizando-o sem possibilidade futura de retirá-lo da margem da sociedade. ${ }^{48}$

Como se vê, a necessidade de se respeitar o conceito de ultima ratio do Direito Penal tem por finalidade a proteção individual e, também, a proteção coletiva.

Portanto, se a pena é o mais forte e agressivo dos instrumentos que dispõe o poder estatal, e se os efeitos nocivos que ela causa são conhecidos, deve ser utilizada como último recurso. ${ }^{49}$

O Direito como um todo (mas especialmente o Direito Penal) não deve pretender atuar de forma ordinariamente repressiva. A repressão deve ser a solução quando realmente necessária. Antes do caráter repressivo, é o caráter pedagógico que deve incidir. ${ }^{50}$

\subsection{A natureza SUbSidiária do Direito Penal}

Ainda que alguns doutrinadores entendam que o princípio da subsidiariedade do Direito Penal tenha equivalente conceito dedicado à ultima ratio, o que no presente trabalho se pretende demonstrar é que o caráter subsidiário do Direito Penal diz respeito, especificamente, à relação que possui com os ramos extrapenais.

Inegável é, logicamente, que a subsidiariedade do Direito Penal está intimamente relacionada ao princípio da intervenção mínima e à noção de ultima ratio. ${ }^{51}$ Tal relação se dá em face do seguinte raciocínio: o Direito Penal é não somente o mais forte e agressivo dos mecanismos estatais (o que legitima que, em face dos efeitos nocivos que gera, seja

\footnotetext{
${ }^{47}$ Idem, ibidem.

${ }^{48}$ LOPES, Maurício Antonio Ribeiro. Princípios políticos do direito penal. 2. ed. São Paulo: RT, 1999, p. 95.

49 JESCHECK, Hans-Heinrich. Tratado de Derecho Penal. Granada: Colmares, 1993, p. 2.

${ }^{50}$ CEREZO MIR, José. Derecho Penal - parte general. São Paulo: RT, 2007, p. 18.

${ }^{51}$ BATISTA, Nilo. Introdução Crítica ao Direito Penal, cit., p. 85.
} 
aplicado no menor grau possível, conforme o princípio da intervenção mínima), como é, também, o ramo do direito que se caracteriza pela intervenção subsidiária aos demais ramos, conforme exposto por SALVADOR NETTO. ${ }^{52}$

Conforme MARQUES, as sanções estabelecidas e executadas pela via penal são um reforço às sanções de outros ramos do direito, atuando de forma a complementá-los. ${ }^{53}$

A subsidiariedade conferida ao Direito Penal pode ser constatada por meio de outro raciocínio, extremamente esclarecedor: se uma prescrição extrapenal não mais existir, também não mais existirá a prescrição penal em relação a mesma matéria, o que comprova que o acessório segue o principal e demonstra que a aplicação da lei penal não se sustenta se nos demais ramos do direito tal matéria não mais é tutelada.

E cabe referir que não se aplica a mesma regra quando ocorrer o inverso: se o adultério deixa de ser crime, por exemplo (não mais surtindo efeitos, portanto, na seara penal), não deixa de produzir efeitos, entretanto, no direito civil. ${ }^{54}$

O caráter subsidiário está comprovado, portanto, na constatação de que o Direito Penal tem sempre como referência um instituto não-penal.

Quando cria punições penais para determinados fatos como matar alguém ou, ainda, subtrair coisa alheia para si ou para outrem, não está a via penal a criar um preceito novo; está, isto sim, a apenas complementar preceitos extrapenais já existentes (nestes exemplos, preceitos relacionados à vida e ao patrimônio).

SOLER explica que um fato ilícito não é contrário somente ao Direito Penal, e sim contrário a todo ordenamento jurídico, já que o alcance das normas penais (e o que elas visam a proteger) é do interesse de todos os ramos do Direito.

Afirma o autor que esta constatação não leva a concluir que o Direito Penal seja temporalmente posterior a todo o restante do ordenamento jurídico. O que ocorre é que há a existência de um princípio positivo que, este sim, é anterior à criação da norma penal, que a ele se vincula. ${ }^{55}$

\footnotetext{
52 SALVADOR NETTO, Alamiro Velludo. Finalidades da pena - conceito material de delito e sistema penal integral. São Paulo: Quartier Latin, 2009, p. 288.

${ }_{53}$ MARQUES, José Frederico. Curso de direito penal - da infração penal. São Paulo: Saraiva, 1956. v. 2, p. 15.

${ }^{54}$ QUEIROZ, Paulo de Souza. Do caráter subsidiário do Direito Penal, cit., p.73.

${ }^{55}$ SOLER, Sebastian. Direito Penal Argentino. Buenos Aires: TEA, 1951, p.12.
} 
MUÑOZ CONDE, muito embora manifeste o desejo de utilizar apenas a expressão “intervenção penal mínima” e não citar expressamente "caráter subsidiário", corrobora a assertiva de que o Estado não pode exercer o poder penal de forma ilimitada, devendo tal poder respeitar sempre as intervenções de outras vias jurídicas em primeiro lugar, para que após, se inevitável, venha a ser utilizado. ${ }^{56}$

O caráter secundário da via penal está manifesto no texto do autor, quando refere que "a norma penal não cria, com efeito, novos valores nem constitui um sistema autônomo de motivação do comportamento humano em sociedade." 57

A realidade demonstra que a incidência do Direito Penal nem sempre respeita esta lógica teórica.

No lugar de deixar para as demais áreas do Direito interferirem em determinadas matérias, a via penal acaba por criar normas penais que tutelam condutas de natureza extrapenal que sequer estão tuteladas na própria área a que pertencem. ${ }^{58}$

Equivale a afirmar que as demais áreas jurídicas muitas vezes dispensam a tutela de determinadas condutas, e justo o Direito Penal (que possui caráter secundário, pautado na intervenção mínima) passa a se preocupar com elas, trazendo-as à esfera penal e aplicando penas a condutas que, pela lógica subsidiária do Direito Penal, deveriam permanecer fora dele.

É o que CEREZO MIR exemplifica com a legislação espanhola. Ainda que o Código Civil espanhol contenha conteúdo amplo e abrangente, a legislação penal preocupou-se, por exemplo, em tipificar criminalmente conduta de falsificação de documento privado (mesmo que não cause prejuízo a terceiros), ainda que a legislação civil tenha ignorado tal conduta. ${ }^{59}$

\footnotetext{
56 MUÑOZ CONDE, Francisco. Introducción al Derecho Penal, cit., p.51. Juan Bustos Ramirez igualmente menciona preferência pela não utilização do termo "direito penal subsidiário". In "Manual de Derecho Penal, parte general", cit., p. 44

${ }^{57}$ MUÑOZ CONDE, Francisco. Introducción al Derecho Penal, cit., p.37.

${ }^{58}$ CEREZO MIR, José. Derecho Penal - parte general. São Paulo: RT, 2007, p. 89.

${ }^{59}$ Idem, ibidem, p. 90.
} 


\subsubsection{A autonomia do Direito Penal Subsidiário}

A relação subsidiária do Direito Penal com as demais áreas jurídicas não leva ao entendimento, de forma alguma, de que o primeiro é subordinado cientificamente às segundas. O reconhecimento da subsidiariedade da esfera penal está dissociado da autonomia científica e legislativa desta esfera em relação às demais. O caráter subsidiário do Direito Penal não prejudica, portanto, sua autonomia científica e legislativa. ${ }^{60}$

Claro que, ainda que cada esfera do Direito tenha sua autonomia científica e legislativa, todas juntas compõem um mundo jurídico único, que não pode ser composto por partes contraditórias ou incompatíveis. A sintonia entre todos os ramos jurídicos deve estar sempre garantida, jamais podendo ser inobservada.

O Estado, por lógico, não poderia adotar para um mesmo fato uma postura na esfera civil que seja contrária à postura adotada na via penal. E esta sintonia de ações nos diferentes ramos jurídicos se dá em torno dos preceitos constitucionais, que regem todo o ordenamento.

Mas há, ainda, outro elemento que leva a concluir que, embora subsidiário, o Direito Penal é autônomo em relação aos outros ramos do Direito.

MAURACH afirma que o Direito Penal é autônomo em relação às consequências que produz, mas é condicionalmente dependente em relação aos seus pressupostos. A independência relacionada às consequências ocorre porque a esfera penal possui mecanismos próprios, autônomos, escolhendo quais são as sanções penais, e as aplicando conforme entender necessário.

Já a dependência relacionada aos pressupostos diz respeito à natureza subsidiária do Direito Penal: para que esteja sendo tutelado pela esfera penal, o fato certamente deve ter gerado alguma outra consequência em distinta área do Direito. ${ }^{61}$

A sua independência em relação às consequências pode ser demonstrada por meio de determinados exemplos.

Um acidente de trânsito é um deles. Este fato pode gerar diferentes entendimentos nas esferas civil e penal. O condutor do veículo pode vir a ser condenado ao pagamento, para o pedestre atropelado, de uma indenização estipulada em conformidade com a

${ }^{60}$ ZAFFARONI, Manual de Direito Penal, cit., p. 58-59.

${ }^{61}$ MAURACH, Reinhart. Derecho Penal. Parte General, cit., p. 36. 
legislação civil. Pode, entretanto, receber sentença absolutória para o crime de lesões corporais no trânsito. ${ }^{62}$

\subsection{O Direito Penal Mínimo e a Subordinação ao TeXto Constitucional}

Certo é que o Direito Penal possui uma relação de subordinação com o texto constitucional. O legislador penal não possui uma liberdade absoluta, e sim relativa, e só pode editar leis penais que estejam em consonância com o texto da Constituição, o que significa dizer que sua legitimidade democrática não lhe permite editar qualquer espécie de lei. ${ }^{63}$

Equivale a afirmar que o legislador penal está materialmente vinculado ao texto constitucional, e esta vinculação se dá especificamente em face dos direitos fundamentais, que representam o maior elo existente nesta relação entre a Constituição e o Direito Penal. ${ }^{64}$

Como a Constituição é a maior fonte de expressão dos princípios fundamentais, e como estes é que norteiam não só a esfera penal como todos os demais ramos do Direito, pode-se identificar que a Carta Maior acaba por virar um verdadeiro concentrado contendo todos os pilares de todo o ordenamento jurídico que norteia a ordem social. ${ }^{65}$

Esta relação se traduz no respeito que a ciência jurídico-penal como um todo deve ter pelo texto constitucional; ainda que possa ser chamada de ciência autônoma, não o é em relação à Constituição. Esta última é que estabelece os limites jurídico-penais e os fundamentos que o estruturam.

BENETI refere que a força que a área jurídico-penal possui não vem tão somente dela própria, e sim do Direito Constitucional. ${ }^{66}$ Não teria o Direito Penal força suficiente para se mostrar tão poderoso frente à sociedade, se não fosse a mão forte constitucional que o protege e legitima.

\footnotetext{
${ }^{62}$ Idem, ibidem, p. 37.

${ }^{63}$ FELDENS, Luciano. A Constituição penal. A dupla face da proporcionalidade no controle de normas penais. Porto Alegre: Livraria do Advogado, 2005, p. 38-39.

${ }^{64}$ Idem, ibdem, p.39.

${ }^{65}$ CARVAlHO, Márcia Dometila Lima de. Fundamentação Constitucional do Direito Penal. Fabris: Porto Alegre, 1992, p. 36-37.

${ }^{66}$ BENETI, Sidnei Agostinho. A Constituição e o sistema penal. Revista Ajuris, Porto Alegre: Ajuris n. 156, 1992, p. 155.
} 
Esta é uma consequência, por certo, do modelo que foi adotado, qual seja, o Estado Social e Democrático de Direito. ${ }^{67}$ Entendida a assertiva de outra forma, pode-se dizer que se o sistema penal é o de mínima intervenção, é porque está derivado de um texto constitucional de igual natureza, ou seja, que prega a liberdade individual e garantias fundamentais aos cidadãos. ${ }^{68}$

Compreende-se, assim, que poderia não ser uma imposição, e sim uma mera consequência de um sistema político já pré-definido.

Pode-se dizer, portanto, que " a Constituição cria potencialmente o direito penal, fixando-lhe as bases e os limites". Criado tal contexto, cabe a uma decisão de estratégia política estabelecer que tais condutas devem, ou não, ser tipificadas. ${ }^{69}$

\subsubsection{O poder limitador da Constituição no Direito Penal}

Em verdade, a Constituição acaba atuando como redutora da atuação da via penal. Esta limitação, exercida pela Carta Maior em relação ao Direito Penal, se dá em duas espécies. ${ }^{70}$

A primeira espécie de limitação é a de natureza material. É vedado ao legislador penal estabelecer disposições penais que sejam contrárias aos direitos e garantias contidos no texto constitucional.

Assim, por exemplo, se a Constituição veda expressamente a aplicação da pena de morte, não poderia haver tipo penal cuja sanção fosse a pena capital. Ainda, se o texto constitucional prevê que é livre a manifestação de pensamento, não pode vir a existir norma penal que puna tal conduta. ${ }^{71}$

\footnotetext{
${ }^{67}$ FELDENS, Luciano. A Constituição penal. A dupla face da proporcionalidade no controle de normas penais, cit., p.43.

${ }^{68}$ BARBERÁ, Gabriel Perez. Teoria Social de Sistemas y Derecho Penal de Minima Intervención. Revista de Derecho Penal, Buenos Aires, p. 137.

${ }^{69}$ QUEIROZ, Paulo de Souza. Do caráter subsidiário do Direito Penal, cit., p.72 e 76.

${ }^{70}$ LOPES, Maurício Antonio Ribeiro. Princípios políticos do direito penal. 2. ed. São Paulo: RT, 1999, p. 167.

${ }^{71}$ Idem, ibidem, p. 95.
} 
A segunda espécie de limitação é a de caráter formal. É vedado ao legislador editar normas que não estejam em consonância com as regras, previstas na Constituição, específicas para a elaboração da legislação penal. ${ }^{72}$

O constituinte preocupou-se em estabelecer diretrizes que norteiam as normas penais. O princípio da anterioridade da lei penal, bem como o princípio da taxatividade, são exemplos dessa limitação formal, que coloca o Direito Penal subordinado aos preceitos constitucionais. $^{73}$

BENETI explica a relação existente entre a Carta Maior e o Direito Penal sem perder de vista o caráter limitador do primeiro em relação ao segundo:

Vemos o Direito Penal encaixando-se na Constituição naquilo que a Constituição o apoia, libera-o; e vemos o Direito Penal limitado pela Constituição naquilo em que a Constituição lhe veda a invasão à esfera de liberdade dos cidadãos. ${ }^{74}$

Uma vez demonstrada a subordinação da esfera penal ao texto constitucional, resta necessário ter-se em vista a idéia de que, para o modelo de Direito Penal Mínimo, esta vinculação se dá de forma ainda mais plena, considerando que a base deste modelo é a supremacia dos direitos constitucionais.

Entende o Direito Penal Mínimo que a função dos princípios constitucionais penais “ao contrário do que possa parecer à primeira vista, não é de legitimar o exercício absoluto do poder punitivo, mas antes condicioná-lo, vinculá-lo, servindo de obstáculos à indiscriminada utilização da punição." 75

Considerando que a atual Constituição brasileira contém um vasto rol de direitos e garantias, bem como uma significativa listagem de princípios penais e processuais, o modelo de Direito Penal Mínimo interpreta que, com isso, não haveria mais que se duvidar da falência de um regime de política criminal pautado no intervencionismo. ${ }^{76}$

\footnotetext{
${ }^{72}$ SILVA, Ivan Luiz da. Princípio da insignificância no direito penal. Curitiba: Juruá, 2011, p. 73.

${ }^{73}$ LOPES, Maurício Antonio Ribeiro. Princípios políticos do direito penal, cit., p. 95.

${ }^{74}$ BENETI, Sidnei Agostinho. A Constituição e o sistema penal, cit., p. 156.

${ }^{75}$ ROBERTI, Maura. A intervenção mínima como princípio no Direito Penal Brasileiro, cit., p.58.

${ }^{76}$ Idem, ibidem.
} 


\section{Capítulo 2. O Bem Jurídico-Penal}

\subsection{NOÇõEs CONCEITUAIS: BEM JURÍDICO COMO FUNDAMENTO DA INCRIMINAÇÃO}

As primeiras noções de bem jurídico surgiram no início do século XIX, com Paul Johann Anselm Feuerbach, na era Iluminista. Se antes, determinada conduta era tida como crime unicamente por lesionar uma norma ética ou divina, a partir do Iluminismo passou a ser obrigatória a demonstração, para a configuração do crime, de lesão a um ou mais interesses de outros indivíduos. ${ }^{77}$

Toda norma penal visa, primordialmente, proteger determinado bem jurídico. A tipificação de determinada conduta não ocorre pura e simplesmente para mera aplicação de uma pena. Ocorre, isto sim, porque algum bem ou interesse foi ferido (ou houve ameaça de ferimento) com a prática de determinada ação (ou omissão).

Para entender o que vem a ser um bem jurídico, deve-se olhar para o texto constitucional. Nele, há menção, direta ou indiretamente, a inúmeros bens (interesses ou valores) que estão previstos exatamente com a intenção de que sejam protegidos.

O constituinte os elencou como direitos e garantias. Eis alguns deles: o direito à vida, o direito à integridade física, o direito de respeito à honra pessoal, o direito ao trabalho, o reconhecimento do patrimônio privado, o reconhecimento de igualdade entre os cidadãos, independentemente de sua cor, raça ou sexo.

Outros bens e interesses estão contidos no texto da Constituição mesmo que não em forma expressa de direitos ou garantias, mas, ainda assim, norteiam o legislador no momento da criação dos tipos penais e da escolha do que será penalmente tutelado. ${ }^{78}$

Assim, utilizando as referências citadas por TAVARES ${ }^{79}$, pode-se afirmar que existem os bens jurídicos individuais (vida, integridade física, honra, liberdade, patrimônio), coletivos (incolumidade pública, meio ambiente, fé pública, paz pública) ou estatais

\footnotetext{
${ }^{77}$ HASSEMER, Winfried. Fundamentos del Derecho Penal, tradução de Francisco Muñoz Conde e Luis Arroyo Zapatero. Barcelona: Bosch, p. 37.

78 GOMES, Mariângela Gama de Magalhães. O princípio da proporcionalidade no Direito Penal brasileiro, cit., p.95.

${ }^{79}$ TAVARES, Juarez. Teoria do injusto penal. 2. ed. Belo Horizonte: Del Rey, 2002, p. 203.
} 
(administração pública, administração da justiça, soberania, ordem pública econômica). Tais bens jurídicos são classificados segundo seu titular.

Ainda, existem os bens jurídicos conforme a percepção, que são: concretos (vida, integridade corporal, patrimônio) e os bens abstratos (incolumidade pública, fé pública, paz pública).

Segundo a natureza, ainda conforme apresentado por TAVARES, existem os bens jurídicos naturais (vida, integridade física, liberdade) e normativos (patrimônio, administração pública, ordem pública econômica).

Por fim, os bens jurídicos de origem real (vida, integridade corporal, saúde), se diferenciam dos bens jurídicos de origem ideal (honra, sentimento religioso), segundo seus elementos.

Pois bem. Estes e tantos outros bens e interesses são utilizados pelo Direito Penal no momento da criação de normas penais. O tipo penal de homicídio, por exemplo, protege o bem jurídico vida. Os crimes de calúnia e difamação protegem o bem jurídico honra. $\mathrm{O}$ crime de lesões corporais protege o bem jurídico integridade física.

O bem jurídico é a base, portanto, de todo tipo penal. Não há como criar tipos penais sem que estes estejam relacionados, diretamente, a um bem juridicamente protegido. Da mesma forma, não há como se pensar em aplicação de pena, se não houver prévio estabelecimento de qual bem jurídico está sendo tutelado. ${ }^{80}$

A função maior do Direito Penal é fomentar o respeito da sociedade em relação aos bens jurídicos, fazendo com que sejam respeitados por meio das normas penais aplicadas. É assim que o Direito Penal obriga os cidadãos a atuar em conformidade com as normas e em obediência ao zelo pelos bens jurídicos. ${ }^{81}$

A tarefa de conceituar e delimitar exatamente o que vem a ser bem jurídico, não é vista com facilidade pelos doutrinadores, conforme ressalta FIGUEIREDO DIAS:

A noção de bem jurídico não pôde, até o momento presente, ser determinada - e talvez jamais o venha a ser - com uma nitidez e segurança que a permita converter em conceito fechado e apto à subsunção, capaz de traçar, para além de toda a dúvida possível, a fronteira entre o que legitimamente pode e não pode ser criminalizado. ${ }^{82}$

\footnotetext{
${ }^{80}$ BUSTOS RAMIREZ, Juan. Manual de Derecho Penal, parte general, cit., p. 45.

${ }^{81}$ CEREZO MIR, José. Derecho Penal - parte general, cit., p. 17.

${ }^{82}$ FIGUEIREDO DIAS, Jorge de. Temas básicos da doutrina penal. Coimbra: Coimbra, 2001, p. 63.
} 
Sendo definido por CONDE e BITENCOURT como todo valor da vida humana protegido pelo Direito, é unanimidade nos dias atuais (conforme preceituam os autores) que o bem jurídico constitui a base da estrutura e interpretação do tipos penais. ${ }^{83}$ São, portanto, o fundamento maior de incriminação no Direito Penal.

Quando se conceitua bem jurídico, como refere BRUNO, deve-se enquadrá-lo como o objeto que é diretamente atingido pela conduta criminosa, saindo-se, assim, "do puro domínio lógico-formal e damos ao conceito do crime um conteúdo em conjunção com a realidade da vida social, em que têm de inspirar-se as definições e aplicação do direito penal." 84

BETTIOL prefere afastar o uso da expressão interesse, para substituí-la pelo termo valores, referindo que "falamos, a propósito do bem jurídico, de valores e não de interesses, visto que valor é o termo mais apropriado para exprimir a natureza ética do conteúdo das normas penais, ao passo que interesse é o termo que exprime uma relação". 85

MIR PUIG assevera que o bem jurídico possui um sentido político-criminal, e um sentido dogmático. No primeiro, está vinculado à proteção jurídico-penal; no segundo, está relacionado aos objetos protegidos pelo Direito Penal. ${ }^{86}$

Ainda que haja certa dificuldade em conceituar bem jurídico, em pelo menos um ponto existe um entendimento unânime, qual seja, de que o bem jurídico atua, no Direito Penal contemporâneo, como principal elemento indicador dos limites do ius puniendi.

Ao atuar nesta condição, passa a ser o "elemento estruturante e informador da política criminal do Estado", legitimando, por conseguinte, a idéia de que crime é a ofensa ao bem juridicamente tutelado. ${ }^{87}$

HASSEMER lembra que as primeiras noções de bem jurídico estavam vinculadas à ofensa a determinado bem da vítima. Esta última passa a ter papel fundamental na discussão sobre delito: a partir do reconhecimento de que a lesão causada atinge um indivíduo específico (ou seja, algum bem ou interesse de determinada pessoa), passa-se a exigir tal

\footnotetext{
83 BITENCOURT, Cezar Roberto. MUNOZ CONDE, Francisco. Teoria Geral do Delito. São Paulo: Saraiva, 2000, p. 140-141.

${ }^{84}$ BRUNO, Anibal. Direito Penal - parte geral. 3. Ed. Rio de Janeiro, Forense, 1967, p. 46.

${ }^{85}$ BETTIOL, Giuseppe. Direito Penal, vol. I. São Paulo: RT, p. 229.

${ }^{86}$ MIR PUIG, Santiago. Derecho Penal, parte general, 5 a ed., Barcelona: Reppertor, 1998, p. 91.

${ }^{87}$ FELDENS, Luciano. A Constituição penal. A dupla face da proporcionalidade no controle de normas penais, cit., p. 44 .
} 
comprovação — da lesão — para que se justifique a aplicação da sanção penal. Se comprovado que houve, de fato, ofensa a um bem ou interesse reclamado pelo indivíduo afetado, restaria comprovada a tipificação do crime. ${ }^{88}$

Como se vê, antes de receber conceituação mais ampla (como a que possui atualmente), a noção de bem jurídico estava mais relacionada à ofensa a um particular.

Um conceito de bem jurídico mais atual, que não se restringe (como ocorria originariamente) a verificar a efetiva lesão a um bem ou interesse apenas de uma vítima, é explicado por HASSEMER quando menciona que o Direito Penal não está apto a se importar com todas as lesões a um bem jurídico, devendo tutelar apenas aquelas que apresentam um caráter socialmente danoso, cujos efeitos lesivos verificados estejam para além do dano individual sofrido pela vítima. ${ }^{89}$

É certo dizer que a teoria do bem jurídico evolui em conformidade com as crescentes demandas sociais, e apresenta crescimento diretamente proporcional às dinâmicas alterações encontradas na teoria do Estado e na teoria do Direito.

A teoria do bem jurídico, em verdade, possui incontestável relevância à formação do Direito Penal contemporâneo, e ainda que se afirme que evolui no tempo e se modifica com os mencionados fatores (relacionados às transformações sociais), o que não muda é o seu papel vinculado à proteção e preservação dos direitos e liberdades individuais, que é caraterístico de um Direito Penal que se mostre comprometido com o modelo de Estado adotado no território brasileiro (cujo modelo jurídico a ser seguido deve ser laico e pluralista). ${ }^{90}$

O que é de suma importância que se considere é que o Direito Penal protege somente alguns bens jurídicos. Apenas os bens jurídicos mais fundamentais é que são (ou deveriam ser) protegidos pela tutela penal, e ainda em relação a eles, somente recebem a atenção penal se a lesão a que foram submetidos for realmente significativa (conforme preceitua o principio da intervenção mínima do Direito Penal), ${ }^{91}$ de acordo com o que se verá adiante.

\footnotetext{
${ }^{88}$ HASSEMER, Winfried. Fundamentos del Derecho Penal, cit., p. 38.

${ }^{89}$ Idem, ibidem.

${ }^{90}$ FELDENS, Luciano. A Constituição penal. A dupla face da proporcionalidade no controle de normas penais, cit., p.44.

${ }^{91}$ QUEIROZ, Paulo de Souza. Do caráter subsidiário do Direito Penal, cit., p. 119.
} 


\subsection{A InfluênCia Social NA ESCOlHa dos BenS JuRídicos a SEREM PENALMENTE TUTELADOS}

LOPES assevera que o conceito material de bem jurídico está intimamente relacionado com as experiências sociais constatadas, que devem ser analisadas primeiro pelo constituinte e, depois, pelo legislador ordinário. Como cada sociedade possui experiências próprias, o conceito de bem jurídico (ou o que o compõe) possui validade somente para um determinado sistema social e, ainda, para um específico momento histórico. ${ }^{92}$

Nesta mesma linha de entendimento, assevera BIANCHINI que “o bem jurídico enquanto produto social, é histórico. Não pertence à sociedade em abstrato, senão que surge de um sistema concreto de relações sociais em determinado período". 93

Isto porque os bens jurídicos não nascem já com este rótulo. São, antes de tudo, uma criação. Tal criação é proveniente de um contexto social, mais vale dizer, de um rol de características de uma determinada sociedade, que possui interesses, necessidades, valores e costumes próprios.

Todos estes elementos geram uma consciência social inicial que, num segundo momento, se transforma num rol de bens (valores e interesses) juridicamente protegidos e declarados expressamente como tal. ${ }^{94}$

Há o entendimento por parte de alguns doutrinadores de que os bens escolhidos para serem jurídica e penalmente protegidos são, em verdade, fruto da influência das camadas sociais mais dominantes, e não apenas fruto do interesse da coletividade, conforme defendem JUAREZ TAVARES e JUAREZ CIRINO DOS SANTOS. ${ }^{95}$

TAVARES explica que todos os bens jurídicos sempre representam um bem do indivíduo, ainda que interesses coletivos estejam envolvidos. Assim, os interesses físcais do

\footnotetext{
${ }^{92}$ LOPES, Maurício Antonio Ribeiro. Princípios políticos do direito penal, cit., p. 106.

${ }^{93}$ BIANCHINI, Alice. Pressupostos materiais mínimos de tutela penal. São Paulo: TR, 2002, p. 39.

${ }^{94}$ FELDENS, Luciano. A Constituição penal. A dupla face da proporcionalidade no controle de normas penais, cit., p. 50 .

95 CARVAlHO, Márcia Dometila Lima de. Fundamentação Constitucional do Direito Penal. Fabris: Porto Alegre, 1992, p. 34.
} 
Estado, como o autor exemplifica, até podem ser considerados como bens coletivos, mas em última análise trata-se de um bem do indivíduo. ${ }^{96}$

A ideia de TAVARES é, portanto, que os bens protegidos estão sempre vinculados ao indivíduo. Mas menciona o doutrinador que, especificamente em relação ao momento da criação da norma (quando então estes bens jurídicos passam a ser protegidos) há uma clara influência dos grupos dominantes.

Defende o autor que as normas são elaboradas conforme os interesses de determinados grupos sociais, que detém força político-social e que possuem o poder de influenciar na criação de normas penais dando a falsa conotação de que os bens eleitos para serem protegidos são única e exclusivamente produto dos interesses sociais, quando na verdade não são. ${ }^{97}$

BIANCHINI concorda, referindo que os bens delineados como protegidos pelo texto constitucional são o resultado dos interesses e das intenções dos grupos sociais que possuam a hegemonia política no momento de escolha de tais bens. A significativa proteção dedicada ao patrimônio, por exemplo, representaria de forma clara a manifestação do capitalismo. $^{98}$

Os bens jurídicos obedecem a uma determinada hierarquia. Isto porque a relação social concreta faz surgir uma determinada prevalência entre eles, que estão sujeitos, ainda, à influência de critérios posteriores devido, sobretudo, à gradual superação social que vai atingindo paulatinamente a humanidade. ${ }^{99}$

PRADO, em obra específica acerca do tema, explica que há um caminho a ser traçado para se chegar ao reconhecimento de um bem jurídico. Fazendo menção aos ensinamentos de E. J. Lampe, refere que tudo inicia com as necessidades individuais de cada um dos cidadãos de uma sociedade. Depois, tais necessidades tornam-se valores culturais. Estes últimos, por fim, sustentam e fundamentam um bem jurídico. ${ }^{100}$

\footnotetext{
96 TAVARES, Juarez. Teoria do injusto penal, cit., p. 203.

${ }^{97}$ TAVARES, Juarez. Critérios de seleção de crimes e cominação de pena. Revista Brasileira de Ciências Criminais. $\mathrm{N}^{\mathrm{o}}$ especial de lançamento, dez. 1992, p. 77.

${ }^{98}$ BIANCHINI, Alice. Pressupostos materiais mínimos de tutela penal, cit., p.38.

${ }^{99}$ CARVAlHO, Márcia Dometila Lima de. Fundamentação Constitucional do Direito Penal, cit., p. 3637.

${ }^{100}$ PRADO, Luiz Regis. Bem Jurídico-Penal e Constituição, cit., p. 44.
} 
BIANCHINI refere que a realidade atual de algumas sociedades caminha para a ampliação da incidência do Direito Penal, com a finalidade de proteção de bens em áreas até então por ele não tuteladas, com o intuito de oferecer tutela a interesses de outros setores populacionais. A tipificação de condutas relacionadas ao meio ambiente, bem como a interferência da via penal em questões que envolvem medicamentos, são alguns dos exemplos.

Tudo leva a concluir que o bem jurídico nada mais é do que um produto da própria sociedade. É ela que escolhe quais são os interesses e bens que devem receber especial atenção da legislação penal. ${ }^{101}$

Os interesses, padrões culturais e padrões de moral de um dado grupo social é que vão determinar quais serão os bens a receber proteção. Ademais, considerando o que já fora exposto, a atuação mais presente de alguns grupos sociais pode, igualmente, produzir como consequência a proteção mais direcionada a este ou aquele bem ou interesse.

GOMES explica que a dinâmica veloz da sociedade acaba por gerar uma permanente atenção para que o rol de bens juridicamente protegidos acompanhe tais modificações. As frequentes transformações ocorridas nas relações sociais exigem que a escolha dos bens esteja acompanhando tal velocidade. ${ }^{102}$

Aqui, uma ressalva se faz vital: os núcleos sociais de fato escolhem, ainda que por via indireta, os bens merecedores de tutela. Estes bens, reitere-se, passam então a ser previstos na Carta Maior. E, após, passam a legitimar toda a produção legislativa de normas penais.

O que é importante referir é que a influência social ocorre tanto em relação ao constituinte (quando cria os preceitos constitucionais), quanto em relação ao legislador penal (quando cria as normas penais).

Primeiro se escolhe quais bens e interesses a Constituição irá prever. Depois, quais bens jurídicos devem receber tutela penal. Em ambas escolhas, a presença da vontade social é manifesta.

Originalmente, é a sociedade que escolhe quais são os bens que devem ser penalmente tutelados. Mas, antes disso, pode-se dizer que é proveniente da própria

\footnotetext{
${ }^{101}$ BIANCHINI, Alice. Pressupostos materiais mínimos de tutela penal, cit., p.38.

102 GOMES, Mariângela Gama de Magalhães. O princípio da proporcionalidade no Direito Penal brasileiro, cit., p.96.
} 
sociedade a escolha dos bens constitucionalmente protegidos. Portanto, os movimentos sociais é que demonstram, por meio de suas necessidades patentes, o que necessita receber tutela. $^{103}$

\subsection{BENS JURídico-PENAIS E SUA RELAÇÃo COM A CONSTITUIÇÃo}

A obrigatória vinculação entre a Constituição e a escolha de bens jurídicos para tutela penal, tem como maior expoente o texto constitucional italiano. No seu artigo 13, prega-se expressamente que a escolha dos bens jurídicos penais deve estar em consonância com as previsões da Carta. ${ }^{104}$

Os bens juridicamente mais relevantes para a sociedade (e que, portanto, são dignos de receber a tutela penal) estão contidos na Magna Carta exatamente porque é ela que rege e orienta as diretrizes do ius puniendi. ${ }^{105}$ Pode-se afirmar, portanto, que a Constituição tem o controle do ius puniendi por meio do bem jurídico.

Entretanto, antes de um bem jurídico ser considerado como tal, deve haver uma prévia definição de quais valores ou interesses é que são socialmente relevantes e dignos de serem elevados ao status de bem jurídico (já demonstrou-se, neste ponto, o papel determinante da sociedade para a escolha dos bens a serem tutelados).

Esta afirmativa leva a concluir que a norma penal não cria valores, o que se traduz no entendimento de que os bens jurídicos não são elevados a tal tão-somente depois da criação das normas penais. ${ }^{106}$ Os bens jurídicos não são mero resultado do que a norma já estipulou. Caso se entenda que bem jurídico é, como já mencionado, fruto de uma junção de características sociais, restaria contraditório que fosse conceituado como fruto das normas penais.

\footnotetext{
${ }^{103}$ PRADO, Luiz Regis. Bem Jurídico-Penal e Constituição, cit., p. 49.

${ }^{104}$ LOPES, Maurício Antônio Ribeiro. Princípio da Insignificância no Direito Penal. SP: RT, 1997, p. 131.

${ }_{105}$ GOMES, Mariângela Gama de Magalhães. O princípio da proporcionalidade no Direito Penal brasileiro, cit., p. 90 .

${ }^{106}$ Há corrente doutrinária contrária a este entendimento, que defende a possibilidade de criação, por parte da norma, de valores.
} 
ROXIN entende bem jurídico como algo metajurídico, que antecede a existência das normas penais (portanto, não deriva delas). Afirma que estas normas, embora não tenham criado o bem jurídico, têm a finalidade de protegê-lo. ${ }^{107}$

O que ocorre é, em verdade, uma recepção jurídico-penal a um determinado bem (que se traduz num valor ou interesse). E tal recepção se dá somente se este bem (valor ou interesse) se traduz em algum direito ou garantia constitucional.

É a Constituição, sensível às vontades e aos interesses sociais, que dita as normas penais o que elas devem conter. Ainda, é o texto constitucional que legitima o reconhecimento (para proteção) de um determinado bem jurídico. Um bem só é juridicamente protegido se verificada sua conformidade com os preceitos constitucionais. ${ }^{108}$

A ideia de que a tutela de bens jurídicos está atrelada aos princípios constitucionais é defendida por PRADO, quando afirma:

O pensamento moderno reconhece que o escopo imediato e primordial do Direito Penal radica na proteção de bens jurídicos - essenciais ao indivíduo e à comunidade norteada pelos princípios fundamentais da personalidade e individualização da pena; da humanidade; da insignificância; da culpabilidade; da intervenção penal legalizada; da intervenção mínima e da fragmentariedade. ${ }^{109}$

Há uma observação relevante. Como se sabe, o poder punitivo acaba por inevitavelmente limitar o exercício da liberdade pessoal do acusado, liberdade esta que é direito fundamental protegido constitucionalmente. $\mathrm{O}$ que se exige é que tal poder punitivo somente pode ser exercido quando se demonstrar que realmente existe uma ofensa a outro direito fundamental que, assim como a liberdade, é também previsto na Constituição.

Esta observação gera a conclusão de que já que o próprio sistema penal, ao atuar, acaba ofendendo um bem constitucionalmente protegido (liberdade pessoal), só está legitimado a agir se for realmente necessária a proteção deste outro bem (que deve possuir relevância no mínimo equivalente ao bem lesionado pela pesada via punitiva). ${ }^{110}$

\footnotetext{
${ }^{107}$ ROXIN, Claus. Problemas básicos de derecho penal. Madrid: Reus, 1976, p.29.

${ }^{108}$ FELDENS, Luciano. A Constituição penal. A dupla face da proporcionalidade no controle de normas penais, cit., p.50.

${ }^{109}$ PRADO, Luiz Regis. Bem Jurídico-Penal e Constituição, 3 ed., São Paulo: Revista dos Tribunais, 2003.

${ }^{110}$ CARBONELL MATEU, Juan Carlos. Derecho Penal: Concepto y Principios Constitucionales. 3. ed. Valencia: Tirant lo Blanch Alternativa, 1999, p.36.
} 
Com isso, o raciocínio a que se chega é que a norma penal somente existe se servir para tutelar situação de ofensa a bem jurídico que, por sua vez, só recebe o status de bem jurídico se devidamente relacionado a uma garantia ou direito constitucional. ${ }^{111}$

\subsubsection{Menção direta ou indireta, no TeXto Constitucional, aOs Bens Que DEVEM SER JURIDICAMENTE TUTELADOS}

Em verdade, esta previsão originária contida na Constituição viria a demonstrar o caráter limitativo da tutela penal. O legislador, para criar normas penais, precisa ter sempre os olhos voltados ao que diz o texto constitucional, observando suas diretrizes e os valores nele consagrados. ${ }^{112}$

Portanto, encontram-se na norma constitucional as linhas substanciais prioritárias para a incriminação ou não de condutas. O fundamento primeiro da ilicitude material deita, pois, suas raízes no Texto Magno. Só assim a noção de bem jurídico pode desempenhar uma função verdadeiramente restritiva. ${ }^{113}$

A Constituição acaba por exercer um trabalho de filtragem dos bens jurídicos merecedores de tutela penal. ${ }^{114}$ A norma penal protege bem jurídico que, ou possui correlação direta ao texto constitucional, ou, se não direta, que seja compatível e convergente com a Carta Maior, e não contrária a ela.

No primeiro caso (de ligação direta com o texto constitucional), estão todos os bens que a Constituição refere expressamente devam ser tutelados. É o que se chama de "imposição constitucional da tutela penal". ${ }^{115}$

Exemplos claros são as menções, na Carta de 1988, ao crime de tortura, ao crime de racismo e ao crime de tráfico ilícito de entorpecentes. Nesses casos, a Constituição não

\footnotetext{
${ }^{111}$ FELDENS, Luciano. A Constituição penal. A dupla face da proporcionalidade no controle de normas penais, cit., p.51.

${ }_{112}^{12}$ LOPES, Maurício Antonio Ribeiro. Princípios políticos do direito penal, cit., p. 106.

${ }^{113}$ Idem, ibidem.

${ }^{114}$ FELDENS, Luciano. A Constituição penal. A dupla face da proporcionalidade no controle de normas penais, cit., p. 52.

${ }^{115}$ BATISTA, Nilo. Introdução Crítica ao Direito Penal, cit., p. 90.
} 
deixa opção ao legislador responsável pelo texto penal: tais situações, que ferem bens jurídicos protegidos constitucionalmente, devem ser tipificadas criminalmente.

Relativamente ao segundo caso mencionado (ausência de menção expressa, na Carta Maior, a determinados bens jurídicos), se a Constituição não possui menção direta e expressa, não significa que tais bens não possam (e não devam) ser protegidos pela norma penal. "Os bens jurídicos protegidos pelo direito penal devem considerar-se concretizações dos valores constitucionais expressa ou implicitamente ligados aos direitos e deveres fundamentais". 116

Essa relação "indireta” dos bens juridicamente protegidos com a Constituição não sugere qualquer problema. Isto porque a carta constitucional, dada sua amplitude axiológica e cultural, não é um texto fechado. A Constituição italiana, por exemplo, não faz menção taxativa à vida como bem juridicamente protegido. Não há como duvidar, entretanto, que a falta de previsão expressa de forma alguma vem a significar que a vida, valiosa como é para todas as sociedades, não deveria ser tutelada. ${ }^{117}$

\section{Nas palavras de FELDENS:}

(...) a tarefa do legislador em primeiro plano, e do intérprete em segunda análise, consistiria em localizar pontos de apoio que permitam a recondução do objeto de tutela a um referente constitucional. Logicamente, essa busca pela referência constitucional há de exercer-se com razoável fundamentação, sob pena de violar-se, e por completo, a noção de Constituição como fonte exclusiva dos bens jurídicos suscetíveis de proteção jurídico-penal, uma vez que poucos seriam os bens dos quais não se possa afirmar que não estejam, pelo menos implicitamente, recepcionados pela Constituição. ${ }^{118}$

GOMES oferece conclusivas argumentações. Ao tratar do tema, refere que de fato nem todos os bens a serem tutelados juridicamente constam de forma expressa no texto constitucional. Afirma, entretanto, que os bens implícitos na Constituição devem ser incluídos no rol dos merecedores de tutela, havendo a necessidade, portanto, de se

\footnotetext{
${ }^{116}$ FIGUEIREDO DIAS, Jorge de. Temas Básicos da Doutrina Penal. Coimbra: Coimbra, 2001, p.6.

117 GOMES, Mariângela Gama de Magalhães. O princípio da proporcionalidade no Direito Penal brasileiro, cit., p.96.

${ }^{118}$ FELDENS, Luciano. A Constituição penal. A dupla face da proporcionalidade no controle de normas penais, cit., p. 53-54.
} 
reconhecer a dilatação de tal rol (que abarca, portanto, tanto os valores implícitos como os explícitos). ${ }^{119}$

Isto porque o texto constitucional tem por finalidade primordial proteger e amparar todos os princípios fundamentais e tudo que venha a fundamentar a relação entre Estado e sociedade. Muito embora o texto constitucional seja caracterizado por delimitadas previsões de disposições, delimitada não deve ser sua amplitude de aplicação e seu grau de abrangência. ${ }^{120}$

Com esta regra, estar-se-ia admitindo o sistema aberto de valores constitucionais, onde existe uma possibilidade de proteger bens que, diante de situações novas (que surgem com a velocidade das modificações sociais) precisam ser tutelados. Não há como ignorar que a dinâmica da sociedade cria novas necessidades, que precisam receber tutela penal. ${ }^{121}$

\section{Conforme GOMES,}

por Constituição aberta, deve se entender aquela em que nem tudo é vinculado em rígidos parâmetros valorativos, mas que existem questões que são, conscientemente, deixadas em aberto para serem avaliadas a partir de um processo político livre. ${ }^{122}$

Lógico é que este sistema aberto não poderia permitir a entrada de todo e qualquer interesse. Se assim fosse, haveria uma incontrolável inflação legislativo-penal.

Para que isso seja evitado, a exigência deste modelo aberto de Constituição é de que a tutela seja aplicada a bens que, ainda que não taxativamente previstos, tenham pressupostos equivalentes aos valores expressos ou, se não isso, que sejam pelo menos “instrumentais à proteção de outros expressamente previstos." 123

PASCHOAL refere que já que a Carta é a principal captadora de todos os valores socialmente relevantes, é ela a principal fonte de diretrizes para o legislador penal. Assim, "enquanto o constituinte busca os bens jurídicos penais na sociedade, o legislador os retira da Constituição". 124

119 GOMES, Mariângela Gama de Magalhães. O princípio da proporcionalidade no Direito Penal brasileiro, cit., p.95.

${ }^{120}$ Idem, ibidem.

${ }^{121}$ Idem, ibidem, p. 97.

${ }^{122}$ Idem, ibidem.

${ }^{123}$ Idem, ibidem, p.98.

${ }^{124}$ PASCHOAL, Janaína Conceição. Constituição, Criminalização e Direito Penal Mínimo. SP: RT, 2003, p. 49. 


\section{Capítulo 3. O PrincíPIO da InSIGNIFICÂNCIA}

\subsection{CONCEITO DE PRINCÍPIO DA INSIGNIFICÂNCIA}

O conceito do princípio da insignificância está intimamente relacionada aos já mencionados conceitos sobre o princípio da intervenção mínima, sobre a natureza subsidiária do Direito Penal e, ainda, seu caráter de ultima ratio.

A junção de todos esses conceitos explica (e, da mesma forma, fundamenta) o princípio da insignificância: o Direito Penal, em face da sua força, é o último recurso a ser utilizado pelo Estado. De acordo com os pilares do princípio da intervenção mínima, só se admite a utilização da mão estatal penal quando todas as demais áreas do Direito não puderem atuar.

Acrescente-se a isso, por fim, as noções de bem jurídico como fundamento de incriminação no Direito Penal. O resultado final da soma destes elementos é a constatação de que uma conduta é insignificante quando não afetar minimamente o bem jurídico protegido e, ainda, quando não justificar que o Estado penal venha a interferir. Essa assertiva fundamenta o princípio da insignificância.

Uma conduta insignificante "é um ataque ao bem jurídico tão irrelevante que não requer (ou não necessita da) intervenção penal. Resulta desproporcional a intervenção penal nesse caso." 125

São as condutas que possuem aparência de tipicidade, mas que em verdade não a possuem em face da inexpressividade que representam, o que legitima não sejam atingidas pela reprovabilidade penal. ${ }^{126}$

Pois bem. Um dos principais questionamentos que surgem em relação à insignificância é o de que sua aplicação acaba por afastar o reconhecimento de tipicidade de um fato que foi reconhecido como tal pelo legislador. Em outras palavras, significa

${ }^{125}$ GOMES, Luiz Flávio. Princípio da Insignificância e outras excludentes de tipicidade. SP:RT, 2009, p. 21.

${ }^{126}$ ACKEL FILHO, Diomar. O princípio da insignificância no Direito Penal. Revista de Jurisprudência do Tribunal de Alçada de São Paulo. SP: TJSP, v. 94, p. 72-77, abr./jun. 1988, p. 35. 
dizer que o aplicador do Direito afasta do plano penal (ao declarar a insignificância) o que o legislador já havia optado por reconhecer como conduta delituosa.

É que o legislador atua no processo de tipificação de forma abstrata, e neste processo acaba incluindo todas as condutas que, numa análise fática futura, se verá que não afetam minimamente o bem jurídico que tutelam. ${ }^{127}$

Verifica-se, portanto, que sob o ponto de vista legislativo, todas as condutas que formalmente se adequam a determinado tipo penal, são consideradas crimes. ${ }^{128}$ Este trabalho legislativo, por lidar com casos em abstrato, não consegue fazer uma diferenciação entre as condutas que lesam minimamente o bem jurídico e as que lesam de forma irrelevante.

O que o princípio da insignificância faz é declarar que determinadas condutas, ainda que formalmente típicas, não o são materialmente, eis que não lesam o bem jurídico de forma suficiente a justificar a atuação estatal penal. Em outras palavras: se no aspecto formal a conduta é típica, em seu conteúdo não é.

Como dito por SILVA, o princípio da insignificância atua como verdadeiro vetor interpretativo ${ }^{129}$ das normas penais e extrapenais, sendo aplicado aos casos concretos em conformidade com a equidade e a razoabilidade, ${ }^{130}$ já que dá vida à norma e aplica-a corretamente no lugar de apenas aplicá-la formalmente.

Como se verifica, o trabalho exercido por este princípio é o de restringir a incidência da norma penal aos casos em que realmente houver ofensa concreta ao bem jurídico. Atua, portanto, como

instrumento de interpretação restritiva do tipo penal, com o significado sistemático e político-criminal de expressão da regra constitucional do nullum crimen sine lege, que nada mais faz do que revelar a natureza subsidiária e fragmentária do Direito Penal. ${ }^{131}$

\footnotetext{
${ }^{127}$ MANÃS, Carlos Vico. O princípio da insignificância como excludente da tipicidade no direito penal. São Paulo: Saraiva, 1994, p. 55.

${ }^{128}$ SANGUINÉ, Odone. Observações sobre o princípio da insignificância. Fascículos de Ciências Penais, $\mathrm{n}^{\circ} 1$, v. 3, p. 46.

${ }^{129}$ Silva, Ivan Luiz da. Princípio da insignificância no Direito Penal. Curitiba: Juruá, 2011, p. 115.

${ }^{130}$ Idem, ibidem.

${ }^{131}$ MAÑAS, Carlos Vico. O princípio da insignificância como excludente da tipicidade no direito penal, cit., p. 56.
} 
A aplicação do princípio da insignificância coloca em prática, na esfera judicial, a opção de afastar do mundo jurídico-penal todas as condutas consideradas bagatelares. Esta atuação demonstra que o princípio tem por fim auxiliar no ideal de um verdadeiro Direito Penal Mínimo, com respeito ao princípio da intervenção mínima penal. ${ }^{132}$

DALBORA chega a tratá-lo como o princípio regulador de todo o sistema de Direito Penal. ${ }^{133}$

Tudo isto porque a lei não pode se tornar dogma, insuscetível de interpretações coerentes e não amparadas nos princípios constitucionais penais. Se assim procedesse o jurista, estar-se-ia mostrando absolutamente descomprometido com as finalidades sociais da legislação vigente. A interpretação da lei, portanto, não pode ocorrer apenas formalmente.

Se o bem jurídico tutelado não sofre lesão suficiente a ensejar reação do Direito Penal, o fato não pode receber outra declaração que não a de atipicidade. Isto porque, conforme FERRAJOLI, os delitos de bagatela não justificam a existência de processo penal, tampouco a aplicação de pena. ${ }^{134}$

Visto sob o aspecto de incriminação, pode-se entender, portanto, que a esfera penal possui um rol de condutas que, por ferirem bens jurídicos relevantes, devem ser reconhecidas como crime. Se o tipo incriminador existe para proteger bem juridicamente relevante, e se tal bem não for infimamente lesado, incide o Princípio da Insignificância. $^{135}$

Visto sob o aspecto punitivo, pode-se mencionar que tal princípio incide (e é, portanto, reconhecida a insignificância), nos casos em que a pena, ainda que aplicada no mínimo grau possível, seria desproporcional frente à irrisória lesão que a conduta causou ao bem jurídico.

Há quem sustente (e não há como não mencionar a existência de tal corrente) que a aplicação do princípio da insignificância poderia gerar uma insegurança social. Esta corrente entende que declarar determinadas condutas insignificantes, ainda que

\footnotetext{
${ }^{132}$ Idem, ibidem, p. 58.

${ }^{133}$ DALBORA, José Luis Guzmán. La insignificancia: especificación y reducción valorativas en el ámbito de lo injusto típico. Revista Brasileira de Ciências Criminais. São Paulo: n. 14, v. 4, p. 41-82, 1996.

${ }^{134}$ FERRAJOLI, Luigi. Derecho e razón, Madrid : Trotta, 2006, p. 477.

135 COELHO, Ediherme Marques. O conceito de crime e a aplicação do Princípio da Insignificância. Cadernos de Estudos Jurídicos Contemporâneos, ano 1, nº1, ago, 2001, p. 65-66.
} 
formalmente típicas, pode abalar a segurança social, que também precisa ser protegida pelo Direito Penal.

Por conseguinte, defende que mesmo as condutas tidas como insignificantes devem ser apreciadas pelo Direito Penal e, se necessário, devidamente punidas.

GRACIA MARTIN ressalta que uma generalização de condutas bagatelares poderia acarretar em grave alteração no correto funcionamento da ordem social. Dá, como exemplo, a conduta de gritar e produzir excessivo barulho pela noite em lugares públicos ou residenciais. Caso a conduta fosse considerada sempre bagatelar, poderia produzir evidente perturbação à segurança pública quando produzida em massa. ${ }^{136}$

\subsection{ORIGEM HISTÓRICA}

A formulação da teoria acerca do princípio da insignificância se deu, indubitavelmente, com direta vinculação aos crimes patrimoniais. Era por meio de crimes desta natureza que se formavam as teses relativas à baixa ofensa ao bem jurídico protegido.

A origem do princípio da insignificância deu-se no direito romano ${ }^{137}$ que, pregando a minima non curat praetor, legitimava a intervenção estatal apenas nos casos em que as condutas ofendiam diretamente algum bem ou interesse do Estado.

Assim, a maioria das infrações penais privadas restava afastada da atuação penal, por entenderem os romanos que não mereciam ocupar o espaço dedicado aos crimes que atentassem contra o Estado. ${ }^{138}$ Surge, assim (embora não expressamente dito como tal) o conceito de condutas que, por serem insignificantes, são retiradas da esfera de tutela penal.

Na era iluminista, com a Declaração Universal dos Direitos do Homem e do Cidadão de 1789, o Princípio da Insignificância — embora também não declarado

\footnotetext{
${ }^{136}$ GRACIA MARTIN, Luis. Fundamentos de dogmática penal: una introducción a la concepción finalista de la responsabilidad penal. Barcelona: Atelier, 2006, p. 224.

${ }^{137}$ Muito embora este seja o entendimento majoritário da doutrina, cumpre referir que DALBORA e LOPES não acreditam na origem romana do princípio da insignificância.

${ }^{138}$ ARRUDA, Élcio. Insignificância: um princípio nada insignificante. Boletim IBCCRIM n ${ }^{\circ}$ 202, set.2009.
} 
explicitamente - está tacitamente contido no artigo $5^{\circ}$ do Texto, com a máxima de que “a lei não proíbe senão as ações nocivas à sociedade (...)”."139

Referido artigo explicita a intenção da Declaração de dedicar ao Direito Penal um caráter seletivo, que deve se despreocupar com condutas insignificantes e olhar apenas para as ações que forem claramente ofensivas no meio social. ${ }^{140}$

E após o período da Segunda Guerra, vem pela primeira vez expresso o termo princípio da insignificância, na obra de Claus ROXIN, publicada em 1964 e chamada Política Criminal y Sistema del Derecho Penal. ${ }^{141} 142$

É que especialmente ao final da Segunda Guerra, a Europa passou a presenciar um significativo incremento no número de crimes bagatelares. Como consequência lógica e previsível, as guerras produziram diretamente uma extraordinária modificação no poder econômico das populações europeias que por elas foram diretamente atingidas. A pobreza dos povos afetados fez gerar um significativo avanço no número de crimes, especialmente os de natureza patrimonial. A formulação da teoria acerca do princípio em estudo se deu, portanto, com direta vinculação aos crimes patrimoniais. ${ }^{143}$

Ao se perceber que parte de tais crimes possuía como característica a pouca relevância da conduta (ou pouca relevância da ofensa que tal conduta produzia no bem jurídico), passou-se a tratar do que para os alemães era chamado de "criminalidade de bagatela" (ou a Bagatelledelikte).

E embora na atualidade o Princípio da Insignificância não esteja mais vinculado estritamente a crimes de natureza patrimonial, na sua origem essa vinculação era inegável. $^{144}$

\footnotetext{
139 Ao referir a menção implícita, na Declaração Universal dos Direitos do Homem e do Cidadão, ao Princípio da Insignificância, tem-se como obrigatória a referência ao Princípio da Legalidade, o que será estudado mais adiante.

${ }^{140}$ LOPES, Maurício Antonio Ribeiro. Princípio da Insignificância no Direito Penal, cit., p. 43.

${ }^{141}$ PRESTES, Cássio Vinicius D. C. V. Lazzari. O Princípio da insignificância como causa excludente da tipicidade no Direito Penal. SP: Memória Jurídica Editora, 2003, p. 36.

${ }^{142}$ Cumpre referir que o termo princípio de bagatela foi mencionado primeiro por Klaus Tiedemann.

${ }^{143}$ LOPES, Maurício Antonio Ribeiro. Princípio da Insignificância no Direito Penal, cit., p. 38-39.

${ }^{144}$ Idem, ibidem, p. 38.
} 


\subsection{LEgitimaÇÃo CONSTITUCIONAL do PRINCÍPIO}

Ainda que a Carta não fale expressamente a respeito da insignificância, seus expressos princípios e garantias a legitimam.

Ao mencionar o reconhecimento constitucional do princípio da insignificância, SILVA menciona que eventual crítica por não ter a Carta Maior uma referência expressa ao princípio "é improcedente, pois é unânime que o texto escrito não exaure todo o direito, cabendo ao operador jurídico explicitar as normas subjacentes na ordem jurídica." ${ }^{145}$

Aliás, ainda que não haja menção expressa, o parágrafo $2^{\circ}$ do $\operatorname{artigo~} 5^{\circ}$ da Constituição declara que "os direitos e garantias expressos nesta Constituição não excluem outros decorrentes do regime e dos princípios por ela adotados, ou dos tratados internacionais em que a República Federativa do Brasil for parte."

Ademais, outros princípios constitucionais que se encontram expressos conseguem abarcar os que estão implícitos.

Em nossa Constituição, como explica SILVA, o princípio da dignidade da pessoa humana se une ao princípio da legalidade (ambos explicitados no texto da Carta) e, juntos, legitimam e amparam o princípio da insignificância. ${ }^{146}$

A vinculação da insignificância (elevada à princípio) com o texto da Carta Maior é incontroverso. Isto porque o trabalho legislativo, por mais detalhado e rigoroso que possa pretender ser, não consegue normatizar todas as situações que merecem tutela penal, até mesmo em face das incontáveis hipóteses concretas que podem surgir.

VICO MANÃS ressalta que o legislador possui a tarefa de, ao prever abstratamente os tipos penais, levar em conta os "modelos da vida" para definir o que merece ser punido. ${ }^{147}$ "Ao realizar o trabalho de redação do tipo penal, o legislador apenas tem em mente os prejuízos relevantes que o comportamento incriminado possa

\footnotetext{
${ }^{145}$ SILVA, Ivan Luiz da. Princípio da insignificância no Direito Penal, cit., p. 107.

${ }^{146}$ Idem, ibidem, p. 112-113.

147 VICO MAÑAS, Carlos. Princípio da insignificância: excludente da tipicidade ou da ilicitude? ESCRITOS em homenagem a Alberto Silva Franco. São Paulo: Revista dos Tribunais, 2003, p. 149.
} 
causar à ordem jurídica e social. Todavia, não dispõe de meios para evitar que também sejam alcançados os casos leves." 148

Sob o ângulo inverso, pode-se concluir que as previsões legislativas podem também inserir previsões legais que, no caso concreto, venha a se verificar que são desproporcionais, por não merecer a conduta uma reprimenda, ou pelo menos não merecer reprimenda do grau de intensidade previsto in abstrato. "O que in abstrato é penalmente relevante pode não o ser verdadeiramente, isto é, pode não assumir, in concreto, suficiente dignidade e significação jurídico-penal." 149

O trabalho legislativo não tem como ser perfeito, e consequência disto é que acaba por abarcar situações que, em determinado caso concreto, não justificam a intervenção penal. ${ }^{150}$

Claro está, portanto, que o princípio em estudo está previsto e acolhido pela Constituição.

\subsection{O PRINCÍPIO DA INSIGNIFICÂNCIA COMO VIA REDUTORA DA REPRESSÃO PENAL}

Ao mesmo tempo em que se verifica que o texto constitucional é a fonte de legitimação e, também a fonte restritiva do Direito Penal, como já analisado, se conclui que o principio da insignificância, originário (ainda que não explicitamente) da Constituição, também possui caráter restritivo, já que sua atuação acaba por "limitar" a atuação da repressão penal.

Em outras palavras: a Constituição atua como limitadora do Direito Penal, e o princípio em estudo age como limitador da punição penal.

Portanto, o princípio da insignificância (que é resultado de uma aplicação prática, na esfera judicial, dos conceitos teóricos vinculados à intervenção mínima) está consequentemente legitimado pelo texto constitucional.

\footnotetext{
${ }^{148}$ VICO MAÑAS, Carlos. Princípio da insignificância: excludente da tipicidade ou da ilicitude?, cit., p. 149.

${ }^{149}$ QUEIROZ, Paulo de Souza. Do caráter subsidiário do direito penal, cit., p. 122.

${ }^{150}$ SANGUINÉ, Odone. Observações sobre o princípio da insignificância. Fascículos de Ciências Penais. Ano 3, 1990, v. 3, n 1, p. 46.
} 
A adoção do princípio auxilia na tarefa de reduzir ao máximo o campo de atuação do direito penal, confirmando seu caráter fragmentário e subsidiário, manifestações naturais da regra de intervenção mínima, reservando-o para tutela jurídica de valores sociais indiscutíveis. ${ }^{151}$

Tal principio, manifestando seu caráter redutor, afasta da esfera penal condutas que não devem nela permanecer, é a verdadeira tradução do que se entende por mínima intervenção penal.

SILVA descreve o princípio da insignificância "como aquele que interpreta restritivamente o tipo penal, aferindo qualitativa e quantitativamente o grau de lesividade da conduta, para excluir da incidência penal os fatos de poder ofensivo insignificante aos bens jurídicos penalmente protegidos.” 152

Conforme VICO MAÑAS, o princípio da insignificância atua "como instrumento de interpretação restritiva do tipo penal, com o significado sistemático e político-criminal de expressão da regra constitucional do nullum crimen sine lege, que nada mais faz do que revelar a natureza subsidiária e fragmentária do direito penal". ${ }^{153}$

Se claro está que devem ser penalmente tutelados apenas os delitos que impedem a realização dos objetivos constitucionais do Estado (leia-se delitos que venham a incrementar a injustiça social e os de natureza verdadeiramente grave, amparados pelos princípios da lesividade ou necessidade), afastando os demais que podem ser discutidos em esferas alienígenas ao Direito Penal (leia-se, aqui, novamente, o direito penal como ultima ratio), ${ }^{154}$ então a aplicação do princípio da insignificância resta mais do que legitimada.

ZIPF, ao tratar do princípio da insignificância ${ }^{155}$, refere-se a aplicação da interpretação restritiva com o intuito de demonstrar que, por meio dela, é possível retirar da esfera jurídico-penal os excessos punitivos. ${ }^{156}$

\footnotetext{
${ }^{151}$ VICO MAÑAS, Carlos. Princípio da insignificância: excludente da tipicidade ou da ilicitude?, cit., p. 150.

${ }^{152}$ SILVA, Ivan Luiz da. Princípio da insignificância no Direito Penal, cit., p. 101.

${ }^{153}$ VICO MAÑAS, Carlos. O princípio da insignificância como excludente da tipicidade no direito penal, cit., 56.

${ }^{154}$ BARATTA, Alessandro. Criminologia Crítica e Crítica ao Direito Penal. 2.E. Rio de Janeiro: Freitas Bastos, 1999.

${ }^{155} \mathrm{O}$ autor alemão utiliza termos como "criminalidade de bagatela" ou "injusto de bagatela", não se valendo do termo "insignificância".
} 
Se a Constituição abriga os princípios máximos de justiça e abriga, ainda, os princípios constitucionais penais, a ofensa ao bem jurídica e penalmente protegido somente é relevante se ferir claramente o que a Carta Maior realmente deseja tutelar. "Deixa assim a ofensa aos citados bens de ter relevância penal, se os princípios constitucionais não restarem por ela arranhados." 157 Esta regra justifica, pois, a afirmação de que a aplicação do principio da insignificância está amparado no texto constitucional.

Por esta razão, o princípio da insignificância, amparado pela Carta Maior, pode exercer papel de filtro no trabalho legislativo, não permitindo que condutas que não lesem efetivamente bens jurídicos sejam objeto de punição penal.

\subsection{CRITÉRIOS DE APLICAÇÃo dO PRINCÍPIO dA INSIGNIFICÂNCIA}

Conforme já referido, não há uma previsão normativa expressa que venha a elencar taxativamente quais são os elementos cuja presença é necessária para a aplicação do princípio da insignificância.

É verdade que existe uma indefinição em relação aos critérios de aplicação desse princípio. Ainda que alguns critérios já tenham sido tacitamente incorporados, no caso concreto podem ser aplicados de forma diversa nas variadas decisões proferidas pelos tribunais brasileiros.

\subsection{1. surgimento dos critérios de aplicação na jurisprudência}

Já que não há previsão normativa a elencar os critérios necessários para aplicação do princípio em estudo, tais requisitos acabaram por ser referidos pela primeira vez no Brasil pela jurisprudência.

\footnotetext{
${ }^{156}$ ZIPF, Heinz. Introducción a la politica criminal. Madrid: Revista de Derecho Privado/Editoriales de Derecho Reunidas, 1979, p. 104.

157 CARVALHO, Márcia Dometila Lima de. Fundamentação constitucional do Direito Penal. Porto Alegre: Fabris, 1992, p. 33.
} 
A inserção do princípio no sistema jurídico brasileiro, feito pela via jurisprudencial, não é contestada, já que incontestável é o papel da jurisprudência como fonte do direito.

GOMES ressalta que a jurisprudência possui forte poder de criação, o que não fere o princípio da legalidade. Ademais, demonstra que o papel legislativo na produção dos tipos penais e definição das penas correspondentes não é lesionado pela atuação da jurisprudência. ${ }^{158}$

Em pesquisa realizada no ano de 2012, sob a coordenadoria do Professor da USP, Pierpaolo Cruz BOTTINI, foram estudados julgados do Supremo Tribunal Federal que envolviam a aplicação do princípio da insignificância. ${ }^{159}$ Os julgados analisados foram proferidos pelo Tribunal entre $1^{\circ}$ de janeiro de 2005 e 31 de dezembro de 2009.

Aludido estudo comprovou que o princípio da insignificância foi invocado em apenas 03 casos até o ano de 2006. A partir deste ano, até 2009, foram 72 casos com menção ao princípio, o que demonstra que sua invocação nos julgados foi crescendo progressivamente ao longo do tempo. ${ }^{160}$

Em outro artigo, publicado posteriormente à pesquisa, BOTTINI faz menção ao crescimento recente de julgados que envolvem a discussão do princípio, ressaltando o caráter de "novidade" que a aplicação do princípio possui nos tribunais pátrios:

Os dados colhidos foram interessantes. Em primeiro lugar, fica claro que a aceitação pelo STF do princípio da insignificância é uma novidade. Há dez anos praticamente não se falava em afastar a repressão penal de comportamento cujo resultado fosse pequeno, bagatelar, como o furto de chocolates ou xampus. Nos últimos tempos, no entanto, a Corte passou a reconhecer com frequência a tese da insignificância, a ponto de o número de decisões reconhecendo-a ter triplicado entre 2007 e $2008 .{ }^{161}$

\footnotetext{
${ }^{158}$ GOMES, Mariângela Gama de Magalhães. Direito Penal e Interpretação Jurisprudencial (do Princípio da Legalidade às Súmulas Vinculantes). SP: Atlas, 2008, p. 40.

${ }^{159}$ BOTTINI, Pierpaolo Cruz. O Princípio da Insignificância nos crimes contra o patrimônio e contra a ordem econômica: análise das decisões do Supremo Tribunal Federal. Pesquisa realizada na Universidade de São Paulo, jun. 2011. Cumpre referir que a integralidade da pesquisa foi publicada pelo autor em link ao final do artigo "Princípio da insignificância no STF é uma novidade", disponível em http://www.conjur.com.br/2011-set-06/direito-defesa-principio-insignificancia-stf-novidade.

${ }^{160}$ BOTTINI, Pierpaolo Cruz. O Princípio da Insignificância nos crimes contra o patrimônio e contra a ordem econômica: análise das decisões do Supremo Tribunal Federal, cit., p. 08.

161 BOTTINI, Pierpaolo Cruz. Princípio da insignificância no STF é uma novidade. Revista Consultor Jurídico, 06.09.2011. Disponível em http://www.conjur.com.br/2011-set-06/direito-defesa-principioinsignificancia-stf-novidade.
} 
Mas foi no julgamento da ação de Habeas Corpus n ${ }^{\circ}$ 84.412, ocorrido no dia 19 de outubro de 2004, que o Supremo Tribunal Federal apresentou de forma inédita um rol expresso de requisitos abstratos para a aplicação do princípio da insignificância, aplicando-os ao caso concreto que estava sendo julgado.

Não é que o princípio nunca tenha sido suscitado em julgados anteriores.

Muito embora o Habeas Corpus nº 84.412 seja o marco referencial de aplicação de critérios objetivos para incidência do princípio da insignificância, foi no julgamento do Habeas $\mathrm{n}^{\mathrm{o}}$ 66.869, de 1988 e sob a relatoria do Ministro Adir Passarinho, que o princípio foi pela primeira vez ventilado em um julgado no Brasil, muito embora sem referência objetiva aos critérios para sua aplicação.

O que ocorreu, no entanto, é que os requisitos de sua aplicação foram tratados explicitamente no Habeas $n^{\circ} 84.412$, com características bem delimitadas, o que gerou inegavelmente um marco na incidência do principio na esfera jurídica brasileira. ${ }^{162}$

O relator do Habeas Corpus, Ministro Celso de Mello, analisou a ação constitucional impetrada em favor de um indivíduo de 19 anos de idade, que teria furtado uma fita de jogos de vídeo-game, cujo valor estimado seria de $\mathrm{R} \$ 25,00$ (vinte e cinco reais) e que recebeu, ao final da ação penal a que respondeu na condição de réu, uma pena de 08 (oito) meses de reclusão.

Os impetrantes alegaram a desproporcionalidade da reprimenda ao afirmar que a vítima do delito tentou, por iniciativa própria, retirar a acusação em desfavor do condenado, o que restou inviabilizado em face do caráter de indisponibilidade de ação penal pública.

Alegaram, ademais, que não houve quaisquer prejuízos para a vítima, tendo em vista que o bem furtado foi a ela restituído.

No voto proferido no Habeas Corpus, foram elencados (ainda que de forma sucinta) os "vetores" (conforme faz referência o julgado) que devem guiar a aplicação do princípio. São eles: a mínima ofensividade da conduta do agente; a nenhuma periculosidade social da ação; o reduzido grau de reprovabilidade da conduta; e a inexpressividade da lesão jurídica provocada.

${ }^{162}$ GOMES, Luiz Flávio. Princípio da Insignificância e outras excludentes de tipicidade, cit., p. 66. 
A decisão manifesta que enquanto o princípio da intervenção penal mínima é destinado especialmente ao legislador e ao trabalho por ele exercido, o princípio da insignificância é destinado aos juízes, que devem aplicá-lo no caso concreto:

Cumpre reconhecer, presente esse contexto, que o direito penal não se deve ocupar de condutas que produzam resultado cujo desvalor - por não importar em lesão significativa a bens jurídicos relevantes - não represente, por isso mesmo, prejuízo importante, seja ao titular do bem jurídico tutelado, seja à integridade da própria ordem social.

Em verdade, os critérios de aplicação nominados na decisão são justificados a todo tempo pela necessidade de reconhecimento da intervenção mínima estatal quando se fala de Direito Penal.

Os chamados "vetores" específicos são justificados, ainda, em clara consonância com o verdadeiro sentido de proteção de bens juridicamente relevantes, relacionados às pessoas e à sociedade, entre outros bens escolhidos como legitimados e merecedores de tutela penal.

Assim refere o julgador:

O sistema jurídico há de considerar a relevantíssima circunstância de que a privação da liberdade e a restrição de direitos do indivíduo somente se justificam quando estritamente necessárias à própria proteção das pessoas, da sociedade e de outros bens jurídicos que lhes sejam essenciais, notadamente naqueles casos em que os valores penalmente tutelados se exponham a dano, efetivo ou potencial, impregnado de significativa lesividade.

A relevância do julgado é incontestável, considerando que representa um marco na aplicação do princípio da insignificância. Entretanto, é evidente que os critérios por ele apontados não são facilmente compreendidos, em face da inexatidão que os termos representam.

Nota-se que são critérios pouco precisos, vagos, abrangentes, que buscam abrigar toda uma gama de casos concretos heterogêneos seja quanto ao bem protegido, seja quanto ao modo de agir. A ausência de parâmetros mais definidos resultou na aplicação díspar do principio, que ora se alarga, ora se comprime, em uma sequência 
aleatória de decisões que reflete a dificuldade de trabalhar com um instituto ainda em construção. ${ }^{163}$

Para compreender o requisito da inexpressividade da lesão provocada no bem juridicamente protegido, tem-se como essencial reiterar que os bens jurídicos que são tutelados pelas normas penais não são nada além de uma mera escolha legislativa. São fruto, portanto, de escolhas político-criminais. E se alguma conduta lhe causar lesão, deve ser devidamente reconhecida na esfera jurídica.

Mas o que se avalia não é a conduta propriamente, e sim o efeito por ela causado. Se o resultado da lesão não for significativo, há legitimidade para aplicar o princípio da insignificância, pois "embora abstratamente relevante, tanto é que fora captada pelo tipo penal, não foi suficientemente alcançada num grau mínimo para legitimar a intervenção concreta do Direito Penal." 164

Para a aplicação deste critério, há um raciocínio a ser feito: primeiro, verificar qual o bem jurídico que está sendo protegido pela norma. O segundo passo é verificar qual a reprimenda que é prevista no tipo penal abstrato, "verificando, por sua gravosidade para o possível acusado, qual o grau de lesão ao bem jurídico protegido que se pretende reprimir com a previsão legal'. O último passo é verificar se há verdadeira relevância jurídico-social na lesão causada. ${ }^{165}$

Trata-se, aqui, do desvalor do resultado. Ainda que conduta formalmente típica tenha sido praticada, o fato é que o efeito por ela causado no bem juridicamente protegido pela norma penal abstrata não apresentou cunho valorativo suficiente.

Quando se fala em desvalor do resultado, está-se referindo aos efeitos negativos que a conduta delituosa produz sobre o bem juridicamente tutelado. Está-se referindo, portanto, à perturbação relevante que o bem jurídico sofre. ${ }^{166}$

\footnotetext{
163 BOTTINI, Pierpaolo Cruz. Princípio da insignificância é um tema em construção. Revista Consultor Jurídico, 26.07.2011. Disponível em http://www.conjur.com.br/2011-jul-26/direito-defesa-principioinsignificancia-tema-construcao.

${ }^{164}$ LOPES, Mauricio Antonio Ribeiro. Princípio da Insignificância no Direito Penal, cit., p. 148.

${ }^{165}$ COELHO, Edilhermes Marques. O conceito de crime e a aplicação do princípio da insignificância, cit., p. 66.

166 GRACIA MARTIN, Luis. Fundamentos de dogmática penal: una introducción a la concepción finalista de la responsabilidad penal, cit., p. 91.
} 
Reitere-se que o importante não é aferir a importância do bem jurídico (até porque se o bem está juridicamente protegido é porque o legislador o considera relevante), e sim a verdadeira expressividade da lesão provocada pela conduta:

A insignificância de determinada conduta deve ser aferida não apenas em relação à importância do bem jurídico atingido, mas especialmente em relação ao grau de sua intensidade, isto é, pela extensão da lesão produzida. ${ }^{167}$

Quanto ao reduzido grau de reprovabilidade da conduta, trata-se, pois, da pouca consequência negativa na esfera social.

Este requisito para reconhecimento da insignificância está diretamente atrelado a um juízo de censura manifestado pela sociedade em relação à conduta praticada. ${ }^{168}$

Trata-se, em verdade, de uma reprovabilidade em relação à conduta de proporções tão ínfimas, que vem a legitimar não seja ela mais do interesse da esfera penal.

E, aqui, entender a dinâmica da sociedade auxilia de forma definitiva no entendimento acerca do que vem a ser um reduzido grau de reprovabilidade da conduta. Isto porque as populações de cada região (de cada cidade, ou de cada estado, ou de cada país) podem apresentar diferentes reações frente a uma mesma conduta.

Se para determinada população de indivíduos, uma conduta $x$ deve receber um tratamento severo em face da lesão que causou a um bem jurídico, para distinta população esta mesma conduta não merece qualquer atenção.

Trata-se, aqui, de justificar tal realidade aceitando a existência de culturas distintas que geram, por conseguinte, entendimentos, sensações, sentimentos e reações igualmente diferenciadas em relação a uma mesma conduta.

Por esta razão, a prática de ação (ou omissão) por parte de um agente pode repercutir de forma muito significativa ou, senão, se forma absolutamente irrisória frente à sociedade.

\footnotetext{
${ }^{167}$ BITENCOURT, Cezar Roberto. CONDE, Francisco Muñoz. Teoria Geral do Delito, cit., p. 164.

${ }^{168}$ LOPES, Mauricio Antonio Ribeiro. Princípio da Insignificância no Direito Penal, cit., p. 142.
} 
Se a consequência da conduta na esfera social for invisível (ou se não invisível, ao menos muito pouco significativa), está-se diante da constatação de um requisito elementar para o reconhecimento do principio da insignificância.

A mínima ofensividade da conduta como critério de aplicação do princípio da insignificância, ainda conforme os vetores elencados no Habeas $n^{\circ} 84.412$, está relacionada com o desvalor da ação praticada. ${ }^{169}$

Mas é geralmente em relação à inexpressividade da lesão ao bem jurídico onde que surgem as maiores divergências em relação à aplicação. Isto porque, dependendo do tipo penal em análise, não há um consenso do que vem a ser lesão inexpressiva.

O dano irrelevante ${ }^{170}$ na condição de critério de aplicação do princípio da insignificância, representa que a constatação de lesão ao bem não pode ser automática e meramente formal.

Não basta, pois, apenas afirmar que houve lesão: deve-se, isto sim, dosá-la. O dano ${ }^{171}$, por exemplo, somente será considerado crime se houver efetivo prejuízo concreto para a vítima; a simples conduta de danificar não é materialmente típica. ${ }^{172}$

Outro exemplo é o descaminho ${ }^{173}$, que só será reconhecido como crime se a conduta efetivamente causar lesão tributária; se o Fisco não for lesado - por ser a quantidade de produto estrangeiro de valor ínfimo - não há ofensa relevante. ${ }^{174}$

\footnotetext{
${ }^{169}$ Aqui, cumpre referir que há uma diferença entre o já mencionado desvalor do resultado e o desvalor da ação. A diferença reside, conforme PRADO, no fato de que "desvalor da ação (dolo/culpa) se refere à forma de praticar o delito (elementos objetivos/subjetivos) e o desvalor do resultado alude à lesão ou perigo de lesão ao bem jurídico protegido.” In PRADO, Luiz Regis. Elementos de Direito Penal. São Paulo: Revista dos Tribunais, 2005, p. 94.

${ }^{170}$ Ao longo do trabalho, trata-se a todo tempo da necessidade de demonstração da efetiva lesão ao bem penalmente protegido para que esteja configurado, de forma efetiva, o crime. Trabalha-se, portanto, com a modalidade de crime de dano, que é aquele que só se consuma com a efetiva lesão ao bem jurídico. Esta lesão é concreta, facilmente visualizada. Sabe-se que há a modalidade de crime de perigo (que pode ser perigo concreto ou abstrato). Nesta modalidade, a lesão ao bem jurídico é apenas presumida. Os crimes de perigo sofrem severas críticas, por serem considerados por muitos como inconstitucionais. Considerando que tais crimes não são objeto do presente estudo, não serão abordados neste trabalho.

${ }_{171}^{17}$ Previsto no artigo 163 do Código Penal brasileiro.

172 TOLEDO, Francisco de Assis. Princípios básicos de direito penal, cit., p. 133.

${ }^{173}$ Previsto no artigo 334 do Código Penal.

${ }^{174}$ QUEIROZ, Paulo de Souza. Do caráter subsidiário do direito penal, cit., p. 124.
} 


\subsection{2. o valor monetário como critério de aplicação do princípio}

A decisão proferida no mencionado Habeas Corpus $n^{\circ} 84.412$ levou em consideração o valor monetário envolvido no caso concreto. O julgador menciona em seu voto o valor do bem furtado $(\mathrm{R} \$ 25,00)$ e o quanto ele representa percentualmente do salário mínimo à época dos fatos.

Assim como este julgado, tantos outros aplicam, quando o tipo penal assim permite, o critério vinculado a valores monetários. É verificado o valor financeiro do prejuízo decorrente da prática delitiva perpetrada, a fim de se avaliar se houve expressiva lesão ao bem juridicamente protegido e, por consequência, se cabe ou não a aplicação do princípio da insignificância.

Em diversos julgados, por exemplo, decide-se qual seria o valor minimamente aceitável do objeto subtraído no crime de furto; no crime de sonegação, qual seria o valor quantitativo minimamente aceitável de tributos sonegados; no crime de descaminho, analisa-se igualmente a expressividade da lesão jurídica provocada verificando se o montante (quantitativo) de produtos estrangeiros causa efetiva lesão ao Fisco.

A título de exemplo tem-se o julgamento do Habeas Corpus $\mathrm{n}^{\circ} 98.152,{ }^{175}$ onde o mesmo julgador responsável pela relatoria do já mencionado Habeas Corpus $n^{\circ} 84.412$, Min. Celso de Mello, fez nova referência a valores monetários para aferir a expressividade da lesão jurídica provocada.

Ao aplicar o princípio da insignificância, referiu que a tentativa de furto simples de cinco barras de chocolate, no valor ínfimo de $\mathrm{R} \$ 20,00$ (vinte reais), equivale a 4,3\% do salário mínimo, o que demonstraria a inexpressividade da lesão.

A utilização de critérios monetários para dosar a inexpressividade da lesão provocada não é consenso na doutrina. Conforme defendem alguns doutrinadores, a aplicação do princípio da insignificância não poderia ficar sujeita a critérios vagos e meramente casuísticos, tendo por referência parâmetros econômicos (como nos casos de furtos considerados insignificantes porque o objeto furtado possui valor financeiro irrisório).

${ }^{175}$ STF, Habeas Corpus no 98.152, Segunda Turma, Min. Celso de Mello, j. 19.05.2009. 
Para esta corrente, ao Direito não caberia apresentar soluções jurídicas com respaldo matemático: "No direito, o referencial é o certo ou o errado, ele veicula regras de aplicação absoluta. Já na economia, o norteamento gira em torno do mais ou do menos, de quantidades e de relações: a relatividade é tônica." $" 176$

A já mencionada pesquisa realizada em 2012 por BOTTINI focou o estudo nos julgados que envolvem crimes patrimoniais comuns, crimes fiscais e crimes contra administração pública.

Demonstrou-se que muitos dos julgados consideram a capacidade econômica da vítima como justificativa para não aplicar o princípio, ainda que o objeto furtado (no crime de furto, por exemplo) seja pequeno. ${ }^{177}$ Do total de julgados analisados, quarenta por cento $(40 \%)$ deles justificou a não aplicação do principio com base na capacidade econômica da vítima. ${ }^{178}$

Mas o valor monetário do(s) bem(ns) envolvido(s) no crime é que mais movimenta os julgados envolvendo o princípio. O valor objetivo da coisa, conforme mencionado pela pesquisa, é o argumento mais utilizado para aplicar a insignificância, equivalendo a $65,9 \%$ dos julgados estudados. ${ }^{179}$

Especificamente em relação aos crimes patrimoniais, verificou-se com a pesquisa que em $60 \%$ dos casos em que os bens eram avaliados entre 0 (zero) a 100 (cem) reais, houve o reconhecimento da insignificância. ${ }^{180}$

Resta claro, portanto, que o valor monetário do bem tem relevância no momento da apreciação do caso.

Em artigo diverso, onde comenta sua pesquisa, BOTTINI faz referência aos valores como parâmetro de aplicação do princípio nos julgados do Supremo Tribunal Federal:

Em $60 \%$ dos casos que envolveram crimes patrimoniais comuns (furto, estelionato) no valor de 0 a $\mathrm{R} \$ 100$ a insignificância foi reconhecida. O número é reduzido a

\footnotetext{
${ }^{176}$ ARRUDA, Élcio. Insignificância: um princípio nada insignificante. Boletim IBCCrim no 202, set.2009.

${ }^{177}$ Conforme gráfico 06, in BOTTINI, Pierpaolo Cruz. O Princípio da Insignificância nos crimes contra o patrimônio e contra a ordem econômica: análise das decisões do Supremo Tribunal Federal. Pesquisa realizada na Universidade de São Paulo, jun. 2011, p. 17.

${ }^{178}$ Conforme gráfico 06, in BOTTINI, Pierpaolo Cruz, cit., p. 19.

${ }^{179}$ Conforme gráfico 07, in BOTTINI, Pierpaolo Cruz, cit., p. 20.

${ }^{180}$ BOTTINI, Pierpaolo Cruz. O Princípio da Insignificância nos crimes contra o patrimônio e contra a ordem econômica: análise das decisões do Supremo Tribunal Federal, cit., p. 50.
} 
$40 \%$ na faixa de $R \$ 201$ a $R \$ 700$ e nulo nos crimes cujo dano foi superior a $R \$$ $700 .^{181}$

Há, entretanto, decisões que afastam os critérios monetários para aferir se o princípio deve ou não ser aplicado.

O decisum do Supremo Tribunal Federal, apresentado a seguir, refuta a apreciação do valor conforme o prejuízo da vítima, tampouco aceita que o salário mínimo seja parâmetro para o reconhecimento da insignificância.

O princípio da insignificância, vetor interpretativo do tipo penal, é de ser aplicado tendo em conta a realidade brasileira, de modo a evitar que a proteção penal se restrinja aos bens patrimoniais mais valiosos, ordinariamente pertencentes a uma pequena camada da população. A aplicação criteriosa do postulado da insignificância contribui, por um lado, para impedir que a atuação estatal vá além dos limites do razoável no atendimento do interesse público. De outro lado, evita que condutas atentatórias a bens juridicamente protegidos, possivelmente toleradas pelo Estado, afetem a viabilidade da vida em sociedade. O parâmetro para aplicação do princípio da insignificância, de sorte a excluir a incriminação em caso de objeto material de baixo valor, não pode ser exclusivamente o patrimônio da vítima ou o valor do salário mínimo, pena de ensejar a ocorrência de situações absurdas e injustas. $^{182}$

Um exemplo de estipulação de valores monetários para aplicação do princípio se dá na previsão contida na Portaria $\mathrm{n}^{\circ} 75$ do Ministério da Fazenda, de 22 de março de 2012. Ela prevê, no inciso II do artigo $1^{\circ}$, “o não ajuizamento de execuções fiscais de débitos com a Fazenda Nacional, cujo valor consolidado seja igual ou inferior a $R \$$ 20.000,00 (vinte mil reais)".

Com esta previsão, deseja estipular o que é penalmente insignificante nos crimes tributários.

\footnotetext{
${ }^{181}$ BOTTINI, Pierpaolo Cruz. Princípio da insignificância no STF é uma novidade, cit.

${ }^{182}$ STF, Habeas Corpus no 84.424, Primeira Turma, Min. Carlos Britto, j. 07.12.2004.
} 


\subsubsection{1. o princípio da oportunidade: o interesse estatal na propositura da ação penal e a insignificância}

Em verdade, ao se aceitar que o valor monetário atua como um critério para aplicação do princípio da insignificância, está-se igualmente aceitando que o princípio pode vir a não ser reconhecido na esfera penal, e sim na esfera processual penal, como defendido por ARMENTA DEU, que em obra específica acerca do tema, vincula a aplicação do princípio estudado ao princípio da oportunidade. ${ }^{183}$

A consequência seria dedicar aos operadores do Direito - no Brasil, ao Ministério Público - a verificação do interesse estatal em iniciar determinada ação penal ou não.

O reconhecimento de que a conduta é insignificante ofereceria ao órgão acusador a faculdade de, consoante o princípio da oportunidade, não requerer seja analisada pelo Direito Penal. ${ }^{184}$ É a possibilidade de prescindir da ação penal. ${ }^{185}$

Um exemplo: verificar-se-iam circunstâncias como, inclusive, o gasto público a ser dedicado a uma ação penal que viesse a julgar uma conduta tida como bagatelar. Caso se constatasse que a conduta causou dano de monta menor do que o que a ação penal custaria ao Estado, poderia o órgão ministerial, amparado no princípio da oportunidade, sequer oferecer denúncia.

A aplicação do princípio da insignificância está diretamente relacionado ao cálculo que se faz: vale a pena instaurar inquérito ou ação penal que traga gastos ao erário público, se o prejuízo causado pela conduta criminosa for desproporcional e infinitamente menor?

Mover o aparato policial e judicial em torno de um prejuízo apenas patrimonial e de pequena monta é atitude que inviabiliza a tomada de decisões mais adequadas em fatos de natureza e importância vitais para a sociedade. ${ }^{186}$

\footnotetext{
${ }^{183}$ ARMENTA DEU, Teresa. Criminalidad de bagatela y princípio de oportunidade. Alemania y España, Barcelona, PPU, 1991, p. 59.

${ }^{184}$ Pode o Ministério Público prescindir da ação penal, em face do reconhecimento da insignificância. Cumpre ressaltar, também, que o magistrado atuante no caso também pode reconhecer a insignificância e não permitir o andamento da ação penal, por meio da rejeição da denúncia.

${ }^{185}$ FERNANDEZ, Gonzalo D. Bien Jurídico y Sistema de Delito. Buenos Aires: Julio César Faira, 2004, p. 165-166. Cumpre referir que embora FERNANDEZ faça a referida menção, é o autor partidário da idéia de que o princípio da insignificância ocorre em face do reconhecimento da atipicidade da conduta (como se verá no $4^{\circ}$ capítulo - excludente de tipicidade). Não entende o autor, portanto, que a aplicação do principio esteja vinculada estritamente a conveniência do órgão acusador.
} 
Se aplicado nestas circunstâncias, inegável é que a conduta do agente, bem como o resultado da lesão por ela causada, sequer precisariam ser debatidos.

Há julgados que, embora não falem expressamente a respeito do principio da oportunidade, o aplicam de forma tácita.

Alguns julgadores se referem aos gastos públicos que uma ação penal pode gerar, e a desproporcionalidade destes gastos com a conduta julgada ou com o prejuízo que ela possa ter causado. Concluem, ao final, que não há razão para movimentar a máquina estatal.

Na decisão monocrática a seguir apresentada, o magistrado julga um crime de atentado violento ao pudor, previsto no artigo 214 do Código Penal. A conduta a ser julgada foi cometida por um indivíduo que, dentro de um transporte público, deu um beijo no rosto de uma mulher, também passageira e desconhecida sua, surpreendendoa. $^{187}$

Ao final da decisão, entendendo pela necessidade de se reconhecer a insignificância da conduta, o julgador defende o caráter de ultima ratio do Direito Penal questionando: "vale a pena? É esse o mister do Direito Processual Penal do século XXI? Ou deveria esse ramo do direito se voltar a apurar aquelas condutas que atinjam bens jurídicos que realmente mereçam a tutela penal?"

Apesar da menção ao caráter subsidiário do Direito Penal, é no princípio da oportunidade que a decisão mais se ampara, já que o julgador enumera detalhadamente todo o gasto público (seja de tempo, seja de dinheiro) para processar e julgar uma conduta insignificante:

Claro que é quase impossível aferir com exatidão as dezenas de profissionais chamados a intervir no presente processo durante a tramitação processual: policiais civis e militares e outros servidores públicos ligados à Secretaria de Segurança Pública do Distrito Federal, ao Ministério Público Distrito Federal e ao Tribunal de Justiça do Distrito Federal, tais como analistas e técnicos judiciários, escrivães,

\footnotetext{
${ }^{186}$ MARQUES, Jader. Rejeição da denúncia, princípio da insignificância e extinção da punibilidade. Revista Síntese de Direito Penal e Processual Penal. v. 3, n. 18, fev./mar. 2003, p. 68.

${ }^{187}$ Decisão monocrática proferida nos autos do Processo no $2007.01 .1 .039400-2,1^{\mathrm{a}}$ Vara de Entorpecentes e Contravenções Penais de Brasília/DF.
} 
oficiais de justiça, diretores e substitutos de cartórios, oficiais de gabinete, executantes, motoristas, seguranças, secretários, garçons, zeladores e faxineiros, eletricistas, digitadores e técnicos em informática, vigilantes e tantos outros que poderiam ampliar imensamente essa lista.

O magistrado segue na narrativa dos gastos, mencionando os profissionais que atuaram mais diretamente na tramitação da ação penal, e conclui demonstrando o tamanho da desproporcionalidade fazendo referência ao valor que o Estado gastou com o pagamento dos salários de todos os envolvidos.

Alguns, talvez os principais desses atores processuais, contudo, ao praticarem atos processuais, deixaram suas assinaturas nos autos do processo, tornando mais fácil a quantificação e enumeração desses sujeitos. Passo a enumerá-los:

10 (dez) juízes de direito;

8 (oito) promotores de justiça;

5(cinco) procuradores de justiça ${ }^{188}$;

9 (nove) defensores;

8 (oito) médicos;

3(três) delegados de polícia.

Esses sujeitos processuais anteriormente discriminados perfazem o total de 43 profissionais altamente especializados que ao longo da tramitação do processo, ou seja, de 20/02/2006 até a presente data (interregno de quase três anos, ou, mais precisamente, dois anos, oito meses e treze dias) receberam dos cofres públicos (considerando-se os respectivos décimos terceiros salários) proventos que podem ser estimados pela média em R \$ 39.674.666,67 (trinta e nove milhões, seiscentos e setenta e quatro mil, seiscentos e sessenta e seis centavos). ${ }^{189}$

\footnotetext{
${ }^{188}$ A atuação de Procuradores de Justiça se deu pelo fato de que o promotor de Justiça, no trâmite da ação, requereu o reconhecimento do princípio da insignificância. A juíza que atuava no caso indeferiu, e remeteu os autos para a Procuradoria de Justiça, que decidiu, em uma comissão composta por três procuradores, pelo seguimento do feito.

${ }^{189} \mathrm{O}$ julgador demonstra ciência de que tais profissionais não atuaram exclusivamente neste caso. "No entanto, tal estimativa serve para evidenciar o tamanho do disparate em direcionar essa estrutura leviatânica para apurar a prática de uma bicota, aliás, uma tentativa de bicota, levada a efeito pelo infeliz acusado."
} 
O magistrado não pretendeu excluir a menção a nenhum gasto, mencionando inclusive os materiais:

Evidentemente, estamos desconsiderando outros custos, como aqueles relacionados a gastos de papel, cartuchos para impressão, cartolina, cordonê e outros materiais e suprimentos de escritório, energia elétrica, comunicação telefônica e via correios, combustível, maquinário diverso et coetera. Por certo, não foi mensurado o inevitável custo do impacto ambiental gerado desde antes da instauração do inquérito até a instauração e encerramento da relação jurídica processual. Ou seja, estimamos apenas uma parte do custo social envolvido com a tramitação do processo do aspirante a beijoqueiro.

Este é um exemplo, talvez o mais explícito, da aplicação do princípio da insignificância nos casos em que os julgadores entendem não haver razão para instauração de ação penal quando a conduta a ser julgada é bagatelar, fazendo valer, aqui, o princípio da oportunidade.

Em outro julgado, a insignificância é reconhecida em face da ausência de ofensividade. Entretanto, o ponto referencial para aplicação do princípio foi o valor do salário mínimo e o quanto, em termos percentuais deste salário mínimo, a conduta criminosa causou de lesão. Conclui-se, assim, que não seria coerente movimentar o Poder Judiciário.

Lesão correspondente a $50 \%$ do mísero salário mínimo não justifica a movimentação de uma máquina cara, cansativa, abarrotada, cruel, como o Judiciário. Cuida-se de valor que dispensa a insurgência punitiva - ultima ratio da interferência controladora estatal -, até bem distante do generoso patamar de $\mathrm{R} \$ 1.000,00$ adotado para alguns setores privilegiados da criminalidade. ${ }^{190}$

Entretanto, a aplicação do princípio da oportunidade pode ser vista com ressalvas. LUZ ressalta dois aspectos relevantes a serem analisados caso a insignificância respeite a oportunidade processual e não material.

${ }^{190}$ TJRS, Apelação Criminal no 70005025119, $5^{\text {a }}$ Câmara Criminal, Des. Amilton Bueno de Carvalho. DJe 05.02.2003. 
A primeira ressalva é a de que a decisão estaria ao livre-arbítrio dos agentes do órgão ministerial. Não deixaria de ser, portanto, uma decisão pautada em critérios que podem variar de agente para agente. ${ }^{191}$

A segunda ressalva é a de que o sistema processual penal brasileiro está regido pelo princípio da indisponibilidade da ação penal pública, o que obrigaria o Ministério Público a oferecer denúncia nos casos de ação penal pública ou condicionada à representação, sob pena de prevaricação. ${ }^{192}$

Como se vê, tudo o quanto foi exposto vem a demonstrar que na falta de critérios expressos na legislação para a aplicação do princípio da insignificância, a jurisprudência acaba por criar regras de cunho objetivo aos casos práticos, sendo que uma delas é avaliar o valor do bem e, após, argumentar se é relevante ou não (seja pelo valor do bem, seja pelos gastos públicos que eventual processo penal poderia causar, seja pela importância que a quantidade monetária possui para a vítima).

\footnotetext{
${ }^{191}$ LUZ, Yuri Corrêa da. Princípio da Insignificância em matéria penal: entre aceitação ampla e aplicação problemática. Revista de Direito $G V \mathrm{n}^{\mathrm{o}}$ 15, jan.jun. 2012, p. 212.

${ }^{192}$ Idem, ibidem, p. 213.
} 


\section{CAPÍtulo 4: CONSEQUÊNCIAS do RECONHECIMENTO DO PRINCÍPIO DA INSIGNIFICÂNCIA}

Quando se reconhece que a conduta é insignificante, acaba-se por gerar uma excludente.

Entretanto, não há consenso, tanto na doutrina quanto nos julgados, acerca de qual é a excludente gerada pelo reconhecimento da insignificância.

Embora sem este consenso, a maioria doutrinária e jurisprudencial defende que o princípio sob estudo localiza-se, dentro da teoria geral do delito, na tipicidade.

GOMES adverte que são as razões político-criminais as responsáveis por levar alguns doutrinadores a defender o afastamento da punibilidade em determinados casos, quando verificada a insignificância. Isto ocorre, conforme a autora, porque entendem que eventual aplicação de sanção penal feriria o princípio da proporcionalidade, já que o bem penalmente protegido não foi minimamente ofendido. ${ }^{193}$

O presente trabalho defende que a consequência do reconhecimento do princípio é a exclusão da tipicidade.

Não deixa, entretanto, de analisar as duas outras exclusões (de ilicitude e culpabilidade).

Passa-se, a seguir, à análise de cada uma delas.

\subsection{EXCLUDENTE DE ILICITUDE}

Quando se fala em antijuridicidade, fala-se nas causas de justificação, que são as permissivas estabelecidas pelo legislador: legítima defesa, estado de necessidade, estrito cumprimento do dever legal e exercício regular de direito.

Entender que a aplicação do princípio da insignificância se dá pela excludente de ilicitude é entender que a conduta, embora típica, estaria justificada juridicamente. A

${ }^{193}$ GOMES, Mariângela Gama de Magalhães. Bases para uma Teoria Geral da Parte Especial do Direito Penal. Tese de Livre-Docência apresentada à Faculdade de Direito da USP, São Paulo, 2012, p. 302. 
essência da insignificância da conduta estaria respaldada na idéia de conduta justificada e, portanto, antijurídica.

Para ressaltar: se na tipicidade trabalha-se com a idéia de normas proibitivas (que são os tipos penais propriamente ditos), na ilicitude se trabalha com as já referidas normas permissivas.

Como se verifica, ambas fazem o estudo objetivo dos fatos; o que importa para ambos são as características objetivas e concretas da conduta praticada, seja ela atípica ou lícita.

Esta característica vem a demonstrar que tanto a excludente de tipicidade quanto a excludente de ilicitude, para fins de justificar a aplicação do princípio da insignificância, passam longe de analisar e considerar as condições subjetivas (sendo a reincidência um exemplo) do agente, ao contrário da excludente de culpabilidade, analisada posteriormente.

Alguns doutrinadores explicam a relação que entendem existir entre a insignificância e a antijuridicidade.

PEREIRA defende que a insignificância pode ser reconhecida como excludente de ilicitude porque é na antijuridicidade que se verifica a efetiva lesão ao bem juridicamente tutelado. Se tal bem não for lesionado, o fato não é significante penalmente. ${ }^{194}$

FRANCO defendeu, em decisão de sua lavra, que a ilicitude é excluída quando verificada a insignificância da conduta, ${ }^{195}$ e DALBORA também compartilha deste entendimento, ressaltando que para estar configurada a antijuridicidade, não basta a mera menção à lesão do bem jurídico ou sua colocação em perigo; o verdadeiro conteúdo material do juízo de antijuridicidade se dá com a verificação de que a ofensa é realmente relevante, o que não tem como ser verificado no plano da tipicidade. ${ }^{196}$

\footnotetext{
${ }^{194}$ PEREIRA, Carlos Frederico. O conceito de bem jurídico e o princípio da insignificância. Revista do Ministério Público Militar. Brasília: MPM, nº 13, p. 45-50, 1991, p. 50.

${ }^{195}$ TACrimSP no 69, Alberto Silva Franco, 23.12.81, p. 441-443.

${ }^{196}$ DALBORA, José Luis Guzmán. La insignificancia: especificación y reducción valorativas en el ámbito de lo injusto típico. Revista Brasileira de Ciências Criminais. São Paulo: n. 14, v. 4, p. 41-82, 1996.
} 


\subsubsection{Crítica: fragilidades}

Entretanto, há críticas em relação à vinculação do principio da insignificância com a excludente de ilicitude.

LUZ apresenta problemas nesta relação, ressaltando que todas as circunstâncias permissivas encontradas nas causas de justificação estão previstas de forma taxativa nas normas penais. Assim ocorre em relação, por exemplo, à legítima defesa: diz o legislador expressamente que, para justificar a ação típica praticada, a agressão sofrida precisa ser injusta, atual ou iminente, conforme expresso no artigo 25 do Código Penal. ${ }^{197}$

Isto significa que caso a insignificância seja considerada uma causa de justificação, deve seguir a regra destinada a esta e estar igualmente prevista de forma expressa na legislação. ${ }^{198}$

Em outras palavras: aqui não interessa a argumentação de que o princípio da insignificância está amparado pela Constituição Federal e que não possui previsão legal. Não seria suficiente esta relação do princípio com o texto da Carta. Deveria, para ser considerado como uma verdadeira circunstância permissiva, estar previamente previsto na legislação.

E mais uma vez LUZ aponta para os problemas que isto poderia gerar.

O primeiro problema é que se houvesse a tentativa de aplicar o princípio da insignificância como circunstância permissiva sem qualquer previsão legal prévia, o princípio da legalidade (que rege as causas supralegais na ilicitude) estaria frontalmente violado,

A vinculação do principio da insignificância ao plano da antijuridicidade traria consigo um paradoxo: por um lado, se tomada como causa supralegal de justificação, teríamos uma violação do principio da legalidade em matéria penal, que não seria respeitado quando da referência a uma circunstância permissiva excepcional não prevista em lei. ${ }^{199}$

197 LUZ, Yuri Corrêa da. Princípio da Insignificância em matéria penal: entre aceitação ampla e aplicação problemática, cit., p. 216.

198 Idem, ibidem.

${ }^{199}$ Idem, ibidem, p. 217. 
Entretanto, para solucionar tal problema seria necessário prever expressamente os casos de incidência do princípio sob estudo, o que causaria novo problema: estaria o princípio, assim, limitado apenas às possibilidades previamente expressas na legislação? $?^{200}$

Não se estaria, dessa forma, reduzindo a incidência do princípio a numerus clausus, e assim retirando dele uma marcante característica de aplicação, que é a análise feita pelo aplicador do Direito (e não pelo legislador) do caso concreto, para verificar se há verdadeira ofensa ao bem juridicamente protegido?

Como se verifica, para que se reconheça a insignificância vinculada à excludente de ilicitude, faz-se necessária a modificação dos critérios de aplicação, o que poderia acarretar em uma significativa redução do número de reconhecimentos do princípio.

Esta, porém, não é a única fragilidade existente. LUZ aponta outra questão de extrema relevância. Se uma conduta for considerada antijurídica no âmbito penal, ela também será em todas as outras áreas do Direito. ${ }^{201}$

Diferentemente da tipicidade (que só surte efeitos na esfera penal), a antijuridicidade afeta todos os ramos jurídicos.

Significa assumir que se a conduta for considerada penalmente insignificante, por ser uma causa de justificação, ela será igualmente insignificante em todas as demais áreas, não podendo ter seus efeitos discutidos em nenhuma esfera jurídica.

Assumir que uma conduta penalmente insignificante não seja base para uma condenação criminal é importante, mas isso não requer a necessidade de tomá-la como algo absolutamente aprovado pela totalidade do ordenamento, tornando impossível, no limite, qualquer tratamento civil ou administrativo para a questão. ${ }^{202}$

O mais importante a se considerar é que esta fragilidade apontada revela uma contradição com a natureza de ultima ratio do Direito Penal. Ao se defender o princípio da intervenção mínima da esfera penal, sugere-se, conforme já estudado, que outras áreas

\footnotetext{
${ }^{200}$ Idem, ibidem.

${ }^{201}$ Idem, ibidem.

${ }^{202}$ Idem, ibidem.
} 
jurídicas devem atuar, deixando de lado a mão pesada penal em situações que áreas alienígenas ao Direito Penal podem atuar de forma inclusive mais eficaz.

Pois se o reconhecimento da insignificância como causa de justificação for aplicado, a conduta não poderá ser discutida em nenhuma outra área jurídica, o que se mostra irrazoável.

A intervenção penal mínima não defende a completa anulação jurídica dos efeitos de uma conduta praticada; defende que tal conduta possa (ou deva) ser debatida em outras áreas do Direito.

MAÑAS, ao criticar o reconhecimento da exclusão de antijuridicidade, faz uma ressalva. Caso reconhecida a insignificância como excludente de ilicitude, estar-se-ia reconhecendo a juridicidade do fato, que não é o que verdadeiramente prega o princípio sob análise. Ao defender a excludente a tipicidade, ressalta que

não afasta a ilicitude pela simples razão de que a irrelevância da conduta, pelo desvalor da ação ou do resultado, pode torná-la estranha ao direto penal, mas não leva necessariamente ao reconhecimento da juridicidade do fato, o que romperia o correto entendimento da ilicitude como contrariedade ao ordenamento jurídico em sentido amplo., 203

Como se verifica, inserir a insignificância na teoria geral do delito como causa de excludente de antijuridicidade pode gerar vários inconvenientes. A insignificância como excludente de ilicitude, muito embora esteja positivamente afastada do direito penal do autor, possui outras características que tornam o modelo contestável.

\subsection{EXCLUdente DE CULPABILIDAdE}

Apenas a título introdutório, cabe ressaltar que para que a conduta seja considerada culpável, deve apresentar três elementos: a imputabilidade, o potencial conhecimento da ilicitude e, ainda, a exigibilidade de conduta diversa.

${ }^{203}$ VICO MAÑAS, Carlos. Princípio da insignificância: excludente da tipicidade ou da ilicitude?, cit., p. 150. 
O reconhecimento da insignificância vinculado à exclusão da culpabilidade estaria construído sob o último dos elementos citados, qual seja, a exigibilidade de conduta diversa.

Resta claro, portanto, que tal entendimento se ampara na desnecessidade de aplicação de pena, já que a conduta é considerada típica, porém não culpável, o que legitimaria o afastamento de aplicação de sanção penal. Não se discute, portanto, se é ou não é crime, e sim se o crime praticado deve ou não ser punido.

$\mathrm{Na}$ tipicidade se discute a conduta propriamente, suas características e, ainda, a efetiva lesão ao bem jurídico que veio a provocar. A atipicidade é verificada analisandose, portanto, os fatos.

Em contrapartida, para que se verifique a excludente de culpabilidade, inevitável é a análise de critérios subjetivos, como antecedentes, comportamento do acusado, personalidade e reincidência, já que tais critérios estão relacionados a necessidade da pena. $^{204}$

Em voz praticamente solitária, CORNEJO defende a inserção da insignificância na esfera da culpabilidade porque acredita que cabe ao magistrado analisar todas as circunstâncias do caso e decidir se deverá o agente da conduta sofrer reprimenda, caso verificada a insignificância.

Cabe ao julgador, sustenta o doutrinador, verificar a necessidade de punir o agente que tenha praticado conduta reconhecidamente insignificante. ${ }^{205}$

NAHUM, entretanto, alerta para a existência de uma diferença entre a inexigibilidade de conduta diversa e o princípio da insignificância.

Diz ele que na aplicação do princípio, não se olha para circunstâncias exteriores (produzidas independentemente da vontade do agente). Vale apenas a "atitude interna". A conduta praticada não sofreu qualquer interferência de fatores externos.

Já na inexigibilidade de conduta diversa, o agente é afetado por tais circunstâncias externas, que influenciam diretamente em sua conduta. ${ }^{206}$

\footnotetext{
${ }^{204}$ GOMES, Luiz Flávio. Princípio da Insignificância e outras excludentes de tipicidade, cit., p. 35.

${ }^{205}$ CORNEJO, Abel. Teoría de la insignificância. 1. ed. Buenos Aires : Ad-Hoc, 1997.

${ }^{206}$ NAHUM, Marco Antonio Rodriguez. Inexigibilidade de conduta diversa. Causa supralegal. Excludente de culpabilidade, cit., p. 104.
} 
Esta crítica acaba por fragilizar a defesa de que há relação entre insignificância e excludente de culpabilidade, tendo em vista que esta última está amparada no seu elemento exigibilidade de conduta diversa.

Concluindo, não é equívoco dizer que na culpabilidade se discute sobre o indivíduo. Os fatos não são o centro da questão.

\subsection{1. crítica: a supremacia do direito penal do autor}

Ao analisar a insignificância sob a perspectiva de excludente da culpabilidade e, com isso, considerar que o indivíduo que cometeu a conduta é o foco maior do debate, está-se diante da supremacia do direito penal do autor.

Desconstrói-se, por conseguinte, tudo o quanto foi dito em relação à necessidade de, utilizando critérios objetivos, retirar do Direito Penal os fatos que nele não devam permanecer.

Isto porque se tais fatos não são o foco do debate, não há mais como controlar o que está ilegitimamente sendo debatido penalmente.

A excludente de culpabilidade como consequência do princípio da insignificância simplesmente desconsidera que o fato pode ser flagrantemente atípico materialmente. Há uma nítida antecipação da análise da culpabilidade quando, na verdade, o que deve ser analisado é se o fato possui todos os elementos da tipicidade. Se não possui, sequer se verificam os elementos da culpabilidade.

Esta afirmativa se traduz na maior crítica feita em relação à excludente de culpabilidade:

É manifesto o desacerto dessa opção, porquanto, segundo o conceito analítico de crime, depois de ultrapassada a tipicidade do fato é que se deve adentrar nas questões atinentes à antijuridicidade e à culpabilidade."207

\footnotetext{
207 BARBOSA Jr, Salvador José. FRANZOI, Sandro Marcelo Paris. MORGADO, Nara Cibele Neves. Breves Anotações do Princípio da Insignificância. Revista IOB de Direito Penal e Processual Penal. Ano VII, nº 41, Dez.Jan.2007, p. 30.
} 
O atropelo à análise da tipicidade material é o que se critica. Conforme LUISI, "somente após se entender tipificado o fato é que se podem considerar as circunstâncias que o cercaram e a vida pregressa de seu autor, para efeito de se aferir sua culpabilidade, e a consequente dosagem da pena." 208

Para os que condenam a aplicação do princípio da insignificância como excludente de culpabilidade, a justificativa está no fato de que os aspectos subjetivos do agente não podem ser considerados no momento de verificar se a conduta é insignificante.

ESTELLITA e LUZ condenam a possibilidade de que outros elementos estranhos ao juízo de tipicidade sejam analisados no momento de aplicar o princípio da insignificância. Ressaltam que é equivocada a análise do sujeito quando se pretende verificar se a conduta é penalmente irrelevante:

Ora, este processo de "pessoalização" do princípio da insignificância, que condiciona a aplicação deste instituto à verificação de uma série de circunstâncias subjetivas e pessoais do autor, não apenas se mostra inconsistente do ponto de vista sistemático, como também, e principalmente, gera graves consequências políticocriminais para todos aqueles pleiteiam a guarida do instituto em sua defesa. ${ }^{209}$

Condena-se a supremacia do direito penal do autor, onde se analisa as condições pessoais do indivíduo, em detrimento do direito penal do fato, onde somente a conduta por ele praticada é que possui relevância.

Para o direito penal do autor, "o castigo da pena não tem por objeto a conduta por ele praticada, mas sim seu sujeito realizador.",210

KATTAH explica a diferença entre o que chama de "fato-do-agente" e "agentedo-fato". O primeiro é a tradução do direito penal do fato, que se preocupa apenas com a

\footnotetext{
${ }^{208}$ LUSI, Luiz. O princípio da insignificância e o pretório excelso. Boletim IBCCrim, Jurisprudência, v. 6, $\mathrm{n}^{\circ}$ 63, fev. 1998.

${ }^{209}$ ESTELLITA, Heloisa. LUZ, Yuri Corrêa da. Tribunais têm manejado equivocadamente a bagatela. Revista Consultor Jurídico, publicado em 21.08.2011. Disponível em http://www.conjur.com.br/2011-ago21/equivocos-principio-insignificancia-ganham-folego-tribunais.

${ }^{210}$ KATTAH, Marina. O princípio da insignificância e sua relação com o moderado direito penal do fato e com o funcionamento teleológico de Roxin. Revista Jurídica do Ministério Público do Estado de Minas Gerais. n. 8, jan./jul. 2007, p. 244.
} 
conduta praticada. O segundo é a tradução do direito penal do autor, onde sua personalidade é o centro do debate. ${ }^{211}$

$\mathrm{Na}$ análise da aplicação do princípio da insignificância, conforme KATTAH, o que importa é a verificação da tipicidade material. Se ela não existir, sequer se analisam elementos subjetivos que atuam exclusivamente na culpabilidade. $\mathrm{O}$ que não pode haver é exatamente esta mistura: analisar na tipicidade os elementos da culpabilidade e, com base nestes dados, negar a aplicação do princípio da insignificância. ${ }^{212}$

Assim, seu inexorável consectário é obstar a análise do juízo de censura que recai sobre o agente, sobre as características deste, sobre os elementos subjetivos inerentes ao fato delituoso os quais, no caso, devem ser entendidos como os relativos às peculiaridades do agente-do-fato. ${ }^{213}$

Assim, para se falar no princípio da insignificância, não há como incluir ao lado do desvalor da ação e do desvalor do resultado um terceiro item que seria o desvalor da culpabilidade. Isto porque o princípio não se presta a discutir critérios subjetivos, estando amparado nos requisitos puramente objetivos para seu reconhecimento e aplicação.

Ao criticar a inserção da insignificância no campo da culpabilidade, SILVA aduz que o princípio em estudo se propõe a discutir a lesividade do fato praticado, e a culpabilidade discute a reprovabilidade do autor do fato, o que torna a relação incompatível. $^{214}$

Ressalte-se, entretanto, que a vinculação da insignificância com aplicação da pena retira do princípio sua finalidade, que é observar a conduta praticada. Se insignificante for, não há que se discutir a imposição de qualquer pena. Esta ideia está muito bem fundamentada nas palavras de LUZ:

Obviamente, a necessidade concreta de pena não pode ser descartada do rol de considerações a serem feitas no processo de imputação penal. Contudo, fixar a atenção apenas sobre esse ponto e construir o princípio da insignificância apenas em torno da culpabilidade parece trazer mais desvantagens do que vantagens. Por isso, talvez seja mais adequado optar por uma concepção de insignificância que afete o

\footnotetext{
${ }^{211}$ Idem, ibidem, p. 245.

${ }^{212}$ Idem, ibidem, p. 244.

${ }^{213}$ Idem, ibidem.

${ }^{214}$ SILVA, Ivan Luiz da. Princípio da insignificância no Direito Penal, cit., p. 168.
} 
próprio status do fato como crime e não apenas a necessidade concreta de sua punição. $^{215}$

A incompatibilidade entre o direito penal do autor e o Direito Penal Mínimo está evidenciada. Sendo a aplicação da insignificância uma expressão de ultima ratio do Direito Penal, não está em convergência com a noção de exclusão de culpabilidade (onde condições pessoais do agente tomam relevo maior do que a análise objetiva dos fatos).

Exemplo desta incompatibilidade será visto no capítulo a seguir, que trata da aplicação do princípio em situações onde as condições pessoais do agente (como reincidência e antecedentes criminais) podem ser um óbice.

\subsection{EXCLUDENTE DA TIPICIDADE}

Esta é a corrente que mais adeptos possui.

Para entender a excludente, oportuno antes introduzir, ainda que de forma sucinta, a tipicidade propriamente dita.

A tipicidade penal é perfeitamente conceituada por TOLEDO:

tipo penal é um modelo abstrato de comportamento proibido. É, em outras palavras, descrição esquemática de uma classe de condutas que possuam características danos ou ético-socialmente reprovadas, a ponto de serem reputadas intoleráveis pela ordem jurídica. ${ }^{216}$

Quando o legislador cria determinados tipos penais, pretende, com isso, abarcar todas as situações que venham a ferir bens juridicamente relevantes. Torna típica, por exemplo, a conduta de matar alguém, ou a conduta de extorquir mediante sequestro.

Dentro da teoria geral do delito, a tipicidade é o primeiro elemento que aparece para que se verifique se a conduta é ou não criminosa.

\footnotetext{
215 LUZ, Yuri Corrêa da. Princípio da Insignificância em matéria penal: entre aceitação ampla e aplicação problemática, cit., p. 215.

${ }^{216}$ TOLEDO, Francisco de Assis. Princípios básicos de Direito Penal, cit., p. 126.
} 
Dentro dessa análise, inicia-se, portanto, verificando se ela é típica, ou seja, se está configurada a tipicidade. Somente após a ilicitude e depois a culpabilidade, serão aferidas.

Há tipicidade, portanto, se a conduta se enquadra nas características que o tipo penal possui. Há tipicidade, assim, se a conduta está subsumida ao tipo penal.

Ao criar os tipos penais, o legislador insere elementos que o configuram (conduta, resultado naturalístico, nexo de causalidade e adequação do fato à letra da lei).

Entretanto, não consegue o legislador, no momento de criação dos tipos penais, ter a certeza de como será sua aplicação in concreto.

Ao desenvolver as previsões normativas, apresenta de forma taxativa quais os elementos necessários ao reconhecimento da tipicidade formal. $\mathrm{O}$ trabalho do legislador não garante, entretanto, que a tipicidade material ande sempre junto à tipicidade formal. $^{217}$

O fato é que, no caso concreto, nem sempre a conduta formalmente típica (ou seja, que preenche todos os elementos contidos no tipo penal) ofende de forma suficientemente significativa o bem jurídico que está sendo protegido pela norma. Se a lesão ao bem for inexpressiva, não há crime, em face da ausência da tipicidade material.

Quando se refere a tipicidade formal, GOMES explica que já não esgota toda a globalidade da tipicidade penal, que ainda requer a dimensão material (que compreende dois juízos distintos: de desaprovação da conduta e de desaprovação do resultado jurídico). Nos crimes dolosos, como se sabe, ainda exige uma terceira dimensão: a subjetiva (imputação subjetiva). ${ }^{218}$

Se a análise recair unicamente sob o aspecto formal, a tipicidade estaria configurada pelo simples cometimento da ação (ou omissão) objetivamente descrita no tipo. Este positivismo exacerbado facilita a imputação de delito, eis que afasta qualquer análise acerca da efetiva e concreta lesão ao bem jurídico e rejeita a idéia de que o dano produzido pode ser socialmente irrelevante.

${ }^{217}$ SANGUINÉ, Odone. Observações sobre o princípio da insignificância, cit., p. 46.

${ }^{218}$ GOMES, Luiz Flávio. Princípio da Insignificância e outras excludentes de tipicidade, cit., p. 73-74. 
A finalidade é, portanto, evitar o mera e superficial juízo de subsunção da conduta ao tipo penal. ${ }^{219}$

Já a conceituação da tipicidade no plano material exige mais do que este mero ajuste formal. Deve haver, neste caso, real valoração da lesão, e verificação dos danos causados ao bem juridicamente tutelado.

\section{Conforme LOPES,}

o juízo de tipicidade, para que tenha efetiva significância e não atinja fatos que devam ser estranhos ao Direito Penal, por sua aceitação pela sociedade ou dano social irrelevante, deve entender o tipo na sua concepção material, como algo dotado de conteúdo valorativo, e não apenas sob seu aspecto formal, de cunho eminentemente diretivo. ${ }^{220}$

Portanto, para que o fato seja típico, não basta estar previsto no ordenamento penal: deve ferir o bem jurídico protegido e tal lesão deve ser expressiva.

Se assim não fosse, não haveria lógica em estabelecer determinados tipos penais se a ação (ou omissão) não causasse resultado efetivamente danoso ao que se pretende proteger (bem jurídico).

TOLEDO explica a tipicidade material mencionando que se trata da verdadeira função seletiva, "apto a distinguir, entre a multidão de comportamentos humanos, aquelas condutas que, por se apresentarem dignas de castigo, necessitam efetivamente submeter-se a processo e julgamento por parte da justiça criminal. "221

Entendida a tipicidade material, portanto, entende-se que a atipicidade material nada mais é do que a constatação de que o fato é insignificante à esfera jurídico-penal. É o que expõe GOMES:

Isso implica que, para a caracterização da tipicidade, não é suficiente a mera adequação da conduta à descrição abstrata da lei, passando-se a exigir um concreto ataque ao bem jurídico. Atos aparentemente subsumíveis à descrição legal, mas de

\footnotetext{
${ }^{219}$ MACIEIRA, Ricardo Felipe R. Princípio da insignificância. Revista Brasileira de Ciências Criminais. v. 4, n. 15, jul./set.1996, p. 357.

${ }^{220}$ LOPES, Maurício Antônio Ribeiro. Princípio da insignificância no direito penal: análise à luz da Lei $n^{o}$ 9.099/95, cit., p. 113.

${ }^{221}$ TOLEDO, Francisco de Assis. Princípios básicos de Direito Penal, cit., p. 121.
} 
entidade objetiva insignificante, sem idoneidade ou potencialidade suficiente para afetar o bem jurídico, devem, portanto, ser considerados atípicos. ${ }^{222}$

Defendendo que a conexão do princípio da insignificância com a atipicidade material, defende FERNANDEZ que "cuando el hecho aparece formalmente subsumible al tipo, pero a causa de su insignificancia ni siquiera llega a afectar el bien jurídico, dogmáticamente el caso debe resolverse en el ámbito de la atipicidad penal, en el plano de la exclusión del tipo objetivo." 223

O princípio da insignificância atua, em verdade, como instrumento judicial de interpretação restritiva (como já visto anteriormente), com a finalidade de retirar da conduta analisada o status de crime, por não ter ela a necessária tipicidade material. ${ }^{224} 225$

MAÑAS também faz referência ao princípio da insignificância como um instrumento de interpretação restritiva, ressaltando que embora possa existir a tipicidade formal, aludido princípio acaba por afastar a configuração de crime, em face da ausência da tipicidade material. ${ }^{226}$

Em outra obra sua, onde explica o afastamento da idéia de exclusão de ilicitude para defender o reconhecimento da exclusão de tipicidade, argumenta:

A concepção material do tipo, em decorrência, é o caminho cientificamente correto para que se possa obter a necessária descriminalização de condutas que, embora formalmente típicas, não mais são objeto de reprovação social, nem produzem danos significativos aos bens jurídicos protegidos pelo direito penal. ${ }^{227}$

GARCIA VITOR igualmente se refere à insignificância como possuidora de natureza restritiva:

\footnotetext{
222 GOMES, Mariângela Gama de Magalhães. Bases para uma Teoria Geral da Parte Especial do Direito Penal, cit., p. 301.

${ }^{223}$ FERNANDEZ, Gonzalo D. Bien Jurídico y Sistema de Delito, cit., p. 166.

${ }^{224}$ BARBOSA Jr, Salvador José. FRANZOI, Sandro Marcelo Paris. MORGADO, Nara Cibele Neves. Breves Anotações do Princípio da Insignificância, cit., p. 30.

${ }^{225}$ BITENCOURT e CONDE também defendem que o reconhecimento da insignificância gera o necessário reconhecimento da exclusão da tipicidade (BITENCOURT, Cezar Roberto. MUÑOZ CONDE, Francisco. Teoria Geral do Delito. São Paulo: Saraiva, 2000, p. 164).

${ }^{226}$ VICO MAÑAS, Carlos. O princípio da insignificância como excludente da tipicidade no direito penal, cit., p. 58.

${ }^{227}$ VICO MAÑAS, Carlos. Princípio da insignificância: excludente da tipicidade ou da ilicitude?, cit., p. 149.
} 
"De lo expuesto, decanta que el princípio de insignificancia representa un criterio de índole interpretativo, restrictivo de la tipicidad de la conduta, partiendo de la consideración del bien jurídico - conceptualizado sobre la base de los princípios de lesividad social e fragmentariedad - y em la medida de su lesión o puesta em peligro concreto." 228

Quando o bem jurídico que se pretende proteger não sofre lesão - ou sofre de forma periférica, em intensidade praticamente irrisória - não há como defender que a tipicidade está presente, como dito por VIRGOLINI. ${ }^{229}$

Se o núcleo do bem jurídico não foi lesionado, falta um dos pressupostos para se garantir que a conduta é típica, embora formalmente possa ser. ${ }^{230}$

Sempre que se chega à conclusão de que a ofensa foi mínima ou insignificante, é dizer, que não alcançou a magnitude suficientemente inequívoca que permite identificar a existência de uma clara situação de risco para o bem jurídico tutelado, resulta mais adequado retirar esse fato do âmbito do penalmente punível, reconhecendo sua insignificância (exclusão de tipicidade)."231

A insignificância, se reconhecida, está a significar a excludente de tipicidade, pois é neste campo (o da tipicidade) que se analisa se o bem jurídico foi lesado. Se comprovado que a conduta não lesionou o bem de forma relevante, a tipicidade material não está configurada. ${ }^{232}$

A atuação restritiva do princípio da insignificância é defendida por ROXIN, que se refere ao princípio como um filtro que exclui lesões sem força suficiente para lesar bens jurídicos.

Aqui pertence igualmente o chamado princípio da insignificância, que permite excluir logo de plano lesões de bagatela da maioria dos tipos: maus-tratos são uma lesão grave ao bem-estar corporal, e não qualquer lesão; da mesma forma, é

\footnotetext{
${ }^{228}$ GARCIA VITOR, Enrique Ulises. La insignificancia em el Derecho Penal. Los delitos de bagatela. Buenos Aires: Depalma, 2000, p. 40.

${ }^{229}$ VIRGOLINI, Julio E. S. Las lesiones levísimas: un caso de atipicidad por insignificancia. Doctrina Penal: Teoría y prática en las ciencias penales, Buenos Aires, v. 8, 29/32, p.119-129, 1985.

${ }^{230}$ QUEIROZ, Paulo de Souza. Do caráter subsidiário do direito penal, cit., p. 123.

${ }^{231}$ GOMES, Luiz Flávio. Princípio da Insignificância e outras excludentes de tipicidade, cit., p. 111.

232 CABETTE, Eduardo Luiz Santos. Informativo n. 489, Saberes jurisprudenciais - 2012 - STF e STJ. Bianchini, Alice (coord.), São Paulo: Saraiva, 2012, p. 169-170.
} 
libidinosa no sentido do código penal só uma ação sexual de alguma relevância; e só uma violenta lesão à pretensão de respeito social será criminalmente injuriosa. Por "violência" não se pode entender uma agressão mínima, mas somente a de certa intensidade, assim como uma ameaça deve ser "sensível”, para adentrar no marco da criminalidade. $^{233}$

Entenda-se, entretanto, que o bem jurídico pode sim sofrer alguma lesão. A insignificância não significa, sempre, que não houve qualquer lesão. Entretanto, esta pode ser irrisória, como acima mencionado, ou, nas palavras de GARCIA VITOR, "la insignificancia constituye un ataque tolerado a um bien jurídico." 234

Não há sequer espaço para se falar em excludente de antijuridicidade ou culpabilidade. Isto porque a partir do momento em que já não está sequer configurado o primeiro dos elementos para a configuração do crime (tipicidade), não há necessidade de se abordar os dois restantes: ilicitude e culpabilidade. ${ }^{235}$

Conforme QUEIROZ, a aplicação do princípio se legitima e legitimada é a consequente exclusão da tipicidade porque o trabalho legislativo cria tipos penais pensando em condutas que, quando típicas, estão subsumidas à previsão legal. Na prática, ocorre a necessidade de se averiguar a existência da tipicidade material.

Se ela não existir, crime não há, ainda que previsto na legislação: "é para obviar os excessos da imperfeição técnica legislativa, que acaba, na prática, por permitir incida o direito penal sobre condutas socialmente insignificantes, que se impõe a aplicação desse princípio [da insignificância]". ${ }^{236}$

E a mencionada prática se dá por meio das decisões judiciais. No paradigmático voto do já referido Habeas Corpus $n^{\circ} 84.412$, julgado pelo Supremo Tribunal Federal, foi dito que o princípio da insignificância qualifica-se como fator de descaracterização material da tipicidade penal:

Como se sabe, o princípio da insignificância - que deve ser analisado em conexão com os postulados da fragmentariedade e da intervenção mínima do Estado em

\footnotetext{
${ }^{233}$ ROXIN, Claus. Politica criminal y sistema de derecho penal, cit.

${ }^{234}$ GARCIA VITOR, Enrique Ulises. La insignificancia em el Derecho Penal. Los delitos de bagatela, cit., p. 36.

${ }^{235}$ BARBOSA Jr, Salvador José. FRANZOI, Sandro Marcelo Paris. MORGADO, Nara Cibele Neves. Breves Anotações do Princípio da Insignificância, cit., p. 30.

${ }^{236}$ QUEIROZ, Paulo de Souza. Do caráter subsidiário do direito penal, cit., p. 125.
} 
matéria penal - tem o sentido de excluir ou de afastar a própria tipicidade penal, examinada na perspectiva de seu caráter material.

Tantos outros julgados seguem esta linha de adoção do princípio da insignificância, acolhendo o argumento de que ele é causa de exclusão da tipicidade material.

Em outra decisão do Supremo Tribunal Federal, manifesto é o entendimento de atipicidade da conduta pela ausência de lesão efetiva ao bem jurídico, o que legitima a aplicação do princípio:

O crime de moeda falsa exige, para sua configuração, que a falsificação não seja grosseira. A moeda falsificada há de ser apta à circulação como se verdadeira fosse. 2. Se a falsificação for grosseira a ponto de não ser hábil a ludibriar terceiros, não há crime de estelionato. 3. A apreensão de nota falsa com valor de cinco reais, em meio a outras notas verdadeiras, nas circunstâncias fáticas da presente impetração, não cria lesão considerável ao bem jurídico tutelado, de maneira que a conduta do paciente é atípica. 4. Habeas corpus deferido, para trancar a ação penal em que o paciente figura como réu. ${ }^{237}$

Conforme a já mencionada pesquisa realizada sob coordenação de BOTTINI, dos julgados do Supremo Tribunal Federal que foram analisados no estudo e que reconheceram o princípio da insignificância, $72,7 \%$ se utilizaram do termo atipicidade para legitimar a aplicação do princípio.

Este dado revela que o Supremo se inclina para o reconhecimento da atipicidade da conduta como justificativa maior para legitimar a aplicação do princípio da insignificância. $^{238}$

Ademais, a abordagem do tema na jurisprudência vem ganhando cada vez mais força e apresentando expressa fundamentação de base constitucional, amparada nos princípios zelados pela Carta Maior.

\footnotetext{
${ }^{237}$ Habeas Corpus n ${ }^{\circ}$ 83.526, Primeira Turma, Relatoria do Ministro Joaquim Barbosa, DJe 07.05.2004.

${ }^{238}$ Vide tabela n. 7, in BOTTINI, Pierpaolo Cruz (coord). O Princípio da Insignificância nos crimes contra o patrimônio e contra a ordem econômica: análise das decisões do Supremo Tribunal Federal, cit.
} 
Claro que, conforme já analisado, esta é a origem do princípio: ele nasce de preceitos constitucionais. Ou seja, a menção à base constitucional da insignificância somente vem a demonstrar o que é inerente ao seu próprio conceito.

Entretanto, como nem sempre esta natureza constitucional é expressamente mencionada (até porque não há previsão constitucional escrita), passa a chamar atenção quando o é.

Exemplo digno de ser revisado é um julgamento proferido no Supremo Tribunal Federal pelo Ministro Ayres Britto. ${ }^{239}$ Nele, fundamenta-se o reconhecimento da insignificância com base no princípio da legalidade penal, previsto no inciso XXXIX da Constituição.

Na medida em que a Carta estabelece que "não há crime sem lei anterior que o defina, nem pena sem prévia cominação legal”, não há como punir conduta que não seja criminosa, refere o voto. E para que seja reconhecida como criminosa, a ação precisa ser dotada de tipicidade material, e não meramente formal.

Merece referência a abordagem do tema, no aludido julgado, porque o aplicador do Direito refere a necessidade de respeito à significância penal, pretendendo, com tal termo, chamar atenção para a obrigatoriedade de reconhecimento apenas das condutas que tenham incontestável valoração jurídica (a ser medida pelo grau de lesividade ao bem jurídico afetado).

E, ao conceder a ordem da ação constitucional para reconhecer a atipicidade da conduta, finaliza o julgado mencionando a necessidade de se analisar o caso concreto para então aplicar os vetores teóricos do princípio da insignificância.

As presentes diretivas de aplicabilidade do princípio da insignificância penal não são mais que diretivas mesmas ou vetores de ponderabilidade. Logo, admitem acréscimos, supressões e adaptações ante o caso concreto.

A afirmativa tem fundamento, já que a atipicidade material não pode ser préestabelecida, tampouco pré-estipulada para determinados tipos legais; seu

\footnotetext{
${ }^{239}$ Habeas Corpus n ${ }^{\circ}$ 109.277, Segunda Turma, DJe 17.02.2012.
} 
reconhecimento só se dará a uma conduta em particular, analisada de forma individualizada. ${ }^{240}$

Não haveria como estabelecer previamente, por exemplo, o liame entre o que é típico e o que é atípico para crimes cuja valoração da lesão é impossível de se aferir materialmente. Em um crime de furto, poder-se-ia estipular valores fixos para estipular o que é insignificante e o que é relevante, conforme estudou-se quando mencionado o valor monetário como requisito de aplicação do princípio. Entretanto, em um crime de honra, como a calúnia, esta regra já não tem efeito.

Como dito por ZAFFARONI, o legislador cria os tipos penais atento à tipicidade formal, mas é o juiz que precisa verificar se há a tipicidade material, e se não houver, incide o princípio da insignificância. 241

Cumpre referir, ademais, que para estar configurada a atipicidade da conduta, deve estar presente o desvalor da ação ou o desvalor do resultado, ou ambos. Conforme já estudado, o primeiro se traduz na completa ausência de relevo da conduta do agente. A prática perpetrada está despida de qualquer relevância.

O segundo - desvalor do resultado - foi anteriormente apresentado quando se mencionou a inexpressividade da lesão causada ao bem jurídico: uma vez que irrisório o resultado da conduta, resta evidente a atipicidade da mesma e, com isso, sua completa insignificância ao mundo jurídico.

Estas são as bases teóricas que compõem o princípio da insignificância. Estão vinculadas ao conceito de tipicidade penal e se traduzem no estudo do "princípio da insignificância do fato" e no "princípio da insignificância do resultado". ${ }^{242}$

Por todos os fundamentos expostos, defende-se que o princípio da insignificância é inserido na teoria geral do delito pela tipicidade e, uma vez reconhecida a necessidade de aplicação do principio, excluída está a tipicidade material.

\footnotetext{
${ }^{240}$ COELHO, Edilhermes Marques. O conceito de crime e a aplicação do princípio da insignificância, cit., p. 66.

${ }^{241}$ Embora ZAFFARONI seja favorável ao reconhecimento da excludente de tipicidade quando verificada a insignificância, é necessário referir que o autor defende a ideia de "tipicidade conglobante", que se traduz na soma da tipicidade material com a antinormatividade. ZAFFARONI, Raul Eugenio. Manual de Direito Penal. SP: RT, 2009.

${ }^{242}$ GOMES, Luiz Flávio. O Princípio da Insignificância e outras excludentes de tipicidade, cit., p. 34.
} 
Este modelo é perfeitamente compatível com um Direito Penal de mínima intervenção, que preza pela interferência da pesada mão penal apenas quando for essencial. $\mathrm{O}$ afastamento da tipicidade, pela insignificância, ocorre nos casos em que realmente não há razão para o Direito Penal atuar.

Ademais, note-se que ao excluir a tipicidade, foram analisados e considerados apenas aspectos estritamente objetivos: se a condita praticada não lesou o bem jurídico e não foi suficientemente importante, não precisa ser discutida penalmente.

Esta característica é de extrema relevância, já que se demonstra que na relação da insignificância com a tipicidade, não há espaço para se analisar o indivíduo que praticou a conduta, e sim apenas e tão somente a conduta por ele praticada. Os fatos estão no centro do debate, e não os indivíduos.

\subsection{1. as condutas típicas de menor potencial ofensivo e a compatibilidade com o princípio da insignificância}

Ainda dentro do campo da tipicidade, convém fazer uma ressalta em relação às chamadas infrações de menor potencial ofensivo.

Estas infrações se caracterizam por não ferirem de forma tão agressiva o bem penalmente protegido, mas não são condutas "fracas" o suficiente para serem consideradas insignificantes.

Surgem as dúvidas, e com elas as críticas a respeito das infrações de menor potencial ofensivo.

O conceito de crime de menor potencial ofensivo surgiu com o advento da Lei $\mathrm{n}^{\circ}$ 9.099, promulgada em 1995. Este tratamento penal previsto na Lei se caracteriza pela implementação de um novo rito processual, que é mais célere e, ainda, prevê institutos diferenciados (como a transação penal e a conciliação). ${ }^{243}$

O artigo 61 da referida Lei prevê que as condutas delituosas submetidas a este rito são as que preveem pena in abstrato de até 01 (um) ano. Assim, crimes e

${ }^{243} \mathrm{O}$ artigo $2^{\circ}$ da referida Lei refere que o rito deve se reger pela oralidade, informalidade, economia processual e celeridade. 
contravenções penais que possuem pena prevista até este patamar são julgados em conformidade com a Lei $\mathrm{n}^{\mathrm{o}} 9.099 / 95$. $^{244}$

Claro está que esta opção legislativa tem por finalidade aplicar um rito processual mais brando para crimes e contravenções penais entendidos como menos nocivos aos bens juridicamente protegidos (tanto é assim que recebem pena máxima de um ano).

Críticas surgem e incrementam o discurso crítico relativo à aplicação do princípio da insignificância. Um dos questionamentos diz respeito à confusão que poderia haver entre os conceitos de conduta insignificante e conduta de menor potencial ofensivo.

A aplicação do princípio da insignificância passa a ser questionada porque representaria o reconhecimento de uma conduta como insignificante quando na verdade ela deveria ser considerada apenas como tendo menor potencial ofensivo.

Muito se questiona se determinada conduta reconhecida como insignificante não deveria, em verdade, sofrer as consequências jurídicas da aludida Lei, no lugar de simplesmente ser afastada das mazelas da esfera penal.

Se já se optou por prever expressamente uma punição penal de menor intensidade relativamente aos crimes que se entende que ferem de forma menos grave os bens jurídicos, poder-se-ia questionar a razão de aplicar a insignificância para determinadas situações. ${ }^{245}$

Inicialmente, ressalte-se que o próprio texto constitucional, no inciso I do artigo 98, estipula que existem crimes de menor potencial ofensivo, o que demonstra que, embora evidente que tais crimes não tenham a força de ferir drasticamente o bem jurídico, o ferem com alguma expressão, que já é suficiente para tornar a conduta materialmente típica.

Assim prevê o texto constitucional:

art. 98: A União, no Distrito Federal e nos Territórios, e os Estados criarão:

${ }^{244}$ Cumpre referir que a Lei $\mathrm{n}^{\circ} 10.259 / 01$, que trata dos crimes de menor potencial ofensivo na esfera federal, estipulou que estão sujeitos ao rito dos juizados especiais criminais os crimes e contravenções penais cuja pena in abstrato seja de no máximo 02 (dois) anos.

${ }^{245}$ LOPES, Mauricio Antonio Ribeiro. Princípio da Insignificância no direito penal: análise à luz da lei 9.099/95, 9.503/97 e da jurisprudência, cit., p.179. 
I - Juizados especiais, providos por juízes togados, ou togados e leigos, competentes para a conciliação, o julgamento e a execução de causas cíveis de menor complexidade e infrações penais de menor potencial ofensivo, mediante os procedimentos oral e sumaríssimo, permitidos, nas hipóteses previstas em lei, a transação e o julgamento de recursos por turmas de juízes de primeiro grau.

O constituinte, como se vê, optou por estipular um patamar mínimo do que pode ser considerado crime, que são as infrações de menor potencial ofensivo. O que está abaixo destas infrações não pode ser abraçado pela esfera penal, porque lhe falta força suficiente para poder típico no aspecto material.

Este patamar, por menor que seja, lesiona o bem jurídico protegido, e a atuação dos Juizados Especiais Criminais se mostra em proporcionalidade a esta lesão menor, já que aplica rito processual mais ameno e institutos diferenciados, como a conciliação e a transação penal.

No já mencionado Habeas Corpus n 109.277, está expressa a ideia de que o legislador optou por não jogar condutas de menor lesividade dentro da esfera mais "pesada" do Direito Penal, e assim estabeleceu o que é o mínimo.

Ao fazê-lo, criou os patamares necessários para a aplicação do princípio da insignificância, que incide em tudo que está abaixo do minimamente lesivo:

Ao prever, por exemplo, a categoria de infrações de menor potencial ofensivo (inciso I do art. 98), a Constituição Federal logicamente nega a significância penal de tudo que ficar aquém desse potencial, de logo rotulado de 'menor'; ou seja, quando a Constituição Federal concebe a categoria das infrações de menor potencial ofensivo, parece mesmo que o faz na perspectiva de uma conduta atenuadamente danosa para a vítima e a sociedade, é certo, mas ainda assim em grau suficiente de lesividade para justificar uma reação estatal punitiva.

Pelo que estabelece um vínculo operacional direto entre o efetivo dano ao bem jurídico tutelado, por menor que seja, e a necessidade de uma resposta punitiva do Estado. ${ }^{246}$

\footnotetext{
${ }^{246}$ STF, Habeas Corpus n 109.277, Segunda Turma, Min. Ayres Britto, DJe 22.02.2012.
} 
Conforme referido em outro julgado, há como se fazer uma distinção entre o que é lesão ínfima ao bem jurídico e o que o fere de forma mais amena, sendo o primeiro insignificante e o segundo abarcado pela Lei $\mathrm{n}^{\circ}$ 9.099/95. No decisum, discute-se a conduta prevista no artigo 155 do Código Penal:

No crime de furto, há que se distinguir entre infração de ínfimo e de pequeno valor, para efeito de aplicação da insignificância. Não se discute a incidência do princípio no tocante às infrações ínfimas, devendo-se, entretanto, aplicar-se a figura do furto privilegiado em relação às de pequeno valor. ${ }^{247}$

Como se percebe, o legislador não previu expressamente a aplicação do princípio da insignificância. Em contrapartida, também não estipulou expressamente a necessidade de punição de condutas de natureza bagatelar. Por consequência, o texto constitucional legitima que seja a insignificância aplicada. ${ }^{248}$

Ademais, há um importante ponto a diferenciar o reconhecimento da insignificância e o reconhecimento de que uma conduta típica é uma infração de menor potencial ofensivo. A primeira tem natureza de direito material. A segunda possui natureza de direito processual. ${ }^{249}$

Isto porque a insignificância se verifica quando tipicidade material não há. Já a aplicação da aludida Lei é uma alternativa processual que atua conforme quantuns de pena.

Em outras palavras: o legislador estipulou, por pura decisão político-criminal, que nos crimes cuja pena máxima não exceda o patamar de 01 ano, o procedimento a ser adotado no processo é o mais célere previsto na Lei.

LOPES, na tentativa de ceifar qualquer confusão que possa haver entre um e outro instituto, refere que "pelo principio se afasta a tipicidade do crime por ausência de seu elemento material; pelo segundo busca-se uma alternativa processual mais célere, pela menor importância do crime (que existe)."250

\footnotetext{
${ }^{247}$ STF, Habeas Corpus no 84.424, Primeira Turma, Min. Carlos Britto, j. 07.12.2004.

${ }^{248}$ SANGUINÉ, Odone. Observações sobre o princípio da insignificância, cit., p. 45.

${ }^{249}$ SILVA, Ivan Luiz da. Princípio da insignificância no Direito Penal, cit., p. 121.

${ }^{250}$ LOPES, Mauricio Antonio Ribeiro. Princípio da Insignificância no direito penal: análise à luz da lei 9.099/95, 9.503/97 e da jurisprudência, cit., p. 50.
} 
A demonstração de que ambos os institutos convivem harmonicamente dentro do Direito Penal (e que a Lei no 9.099/95 não deslegitima a aplicação do princípio) se dá, portanto, em face da constatação, conforme defende SILVA, de que consistem em técnicas de despenalização com natureza jurídica diversa.

O principio da insignificância e a Lei $\mathrm{n}^{\text {o }}$ 9.099/95 consistem em técnicas de despenalização de natureza jurídica distinta; pois, enquanto aquele é uma solução penal de natureza material, esta última insere-se entre as soluções de caráter processual. Em sendo assim, não vislumbramos óbice algum na coexistência de ambos os institutos no sistema penal brasileiro. ${ }^{251}$

Outro ponto relevante a se considerar é que ainda que haja uma confusão inicial em relação ao grau de lesividade da conduta e, mesmo bagatelar, acabe por ser inserida nos Juizados Especiais Criminais, pode haver o reconhecimento da insignificância, em face da atipicidade da conduta. ${ }^{252}$ Assim, nada obsta que, mesmo estando na esfera destes Juizados, a conduta não possa ser considerada insignificante, se assim restar demonstrado. ${ }^{253}$ "O magistrado deve rejeitar o acordo feito entre o Ministério Público e o autor do fato se entender que se trata de crime de bagatela - conduta penalmente insignificante - e não de infração de menor potencial ofensivo." 254

Porém, considerando tudo o quanto exposto até aqui, no sentido de demonstrar o caráter minimamente intervencionista que o Direito Penal deve ter, poder-se-ia questionar: por qual razão o legislador decidiu incluir na esfera penal estas infrações que ferem os bens jurídicos de forma tão pequena?

De fato, conforme refere MANÃS ao criticar a legislação que estipula as infrações de menor potencial ofensivo, a natureza fragmentária e subsidiária do Direito Penal exige que este só venha a intervir "nas hipóteses em que a vida em sociedade é

\footnotetext{
${ }^{251}$ SILVA, Ivan Luiz da. Princípio da insignificância no Direito Penal., cit., p. 123.

${ }^{252}$ Idem, ibidem, p. 124.

${ }^{253}$ MAÑAS, Carlos Vico. O princípio da insignificância como excludente da tipicidade no direito penal, cit., p. 63.

${ }^{254}$ SANTOS, Lycurgo de Castro. Princípio da intervenção mínima do direito penal e crimes de menor potencial ofensivo - Lei 9.099/95. Revista Justiça e Democracia. São Paulo: RT, n. 1, p. 198-206, 1996, p. 123.
} 
atingida de maneira intolerável e grave. Não lhe cabe cuidar, portanto, de pequenas ofensas aos bem jurídicos. "255

Se a lesão ao bem jurídico é tão pequena, não caberia ao Direito Penal, com sua natureza de ultima ratio, se preocupar com ela. Como já estudado, tal responsabilidade poderia ter sido transferida para outras áreas do Direito.

Muito embora a Lei no 9.099/95 tenha por finalidade aplicar o Direito Penal de forma mais branda, fato é que está inserida dentro desta esfera jurídica que, como já analisado, tem natureza inevitavelmente severa. Esta esfera, por mais branda que intente ser, nunca o é efetivamente. A natureza do Direito Penal, por si só, já possui uma forte carga estigmatizante, tanto para o agente da conduta quanto para a própria vítima, inclusive.

${ }^{255}$ MAÑAS, Carlos Vico. O princípio da insignificância como excludente da tipicidade no direito pena, cit., p. 63. 


\section{Capítulo 5. PRoblemática na APliCaÇÃo do PRINCÍPIO DA INSIGNIFICÂNCIA}

Em determinadas situações jurídicas, a incidência do princípio da insignificância causa expressivas divergências entre as opiniões doutrinárias e jurisprudenciais. Nestas situações não há um consenso sobre sua aplicação.

Este cenário de divergências surge, por exemplo, quando a reincidência é trazida para o debate, e quando se discute se o princípio da insignificância pode ser aplicado em casos onde a primariedade do agente não mais existe.

Ainda, as divergências também ocorrem quando o agente não necessariamente é reincidente tecnicamente, mas possui antecedentes em seu histórico.

A problemática se estende para as situações que envolvem os crimes complexos ou os praticados com violência ou grave ameaça.

O presente estudo, é válido ressaltar, não pretende desenvolver as teses contra ou a favor da legitimidade do instituto da reincidência (considerado inconstitucional por muitos doutrinadores). $\mathrm{O}$ debate estará restrito especificamente à relação existente entre a reincidência e a aplicação do princípio da insignificância, este sim o núcleo principal do estudo. A mesma referência vale para os antecedentes.

Aqui, existem três possibilidades a serem discutidas.

A primeira delas diz respeito a uma reiteração de práticas de mesma natureza, consideradas insignificantes. Trata-se, portanto, da reiteração de condutas semelhantes, tidas como bagatelares.

A segunda possibilidade se assemelha à primeira. Há uma reiteração de práticas delitivas que, se analisadas, demonstram serem individualmente insignificantes. A diferença reside no fato de que possuem, cada uma delas, distinta natureza, e atingem, portanto, variados bens jurídicos.

A terceira possibilidade a ser mencionada é a que trata do indivíduo que comete uma conduta insignificante, mas que já possui em seu histórico judicial o status de reincidente pelo cometimento de outro ou outros crimes. 
Para todas as citadas modalidades há divergência doutrinária e jurisprudencial em relação à aplicação do princípio sob estudo.

Em obra específica sobre o tema, GOMES oferece interessante abordagem a respeito das hipóteses e apresenta uma nomenclatura própria para defini-las e diferenciálas, a saber: a "multirreincidência ou reiteração cumulativa", a "multirreincidência ou reiteração não cumulativa" e, por fim, o "fato único cometido por um agente já considerado reincidente". 256

As três possibilidades ventiladas pelo autor serão mencionadas no presente estudo, cada uma delas devidamente analisada sob a ótica de diferentes entendimentos, ainda que a nomenclatura utilizada por GOMES seja de exclusividade sua.

\subsection{A REITERAÇÃO DE CONDUTAS DE MESMA NATUREZA: A CONTINUIDADE}

Esta modalidade é denominada por GOMES de "multirreincidência ou reiteração cumulativa" de atos tidos como insignificantes. Entende o autor que se trata de uma situação composta de condutas a princípio irrelevantes, mas que pela reiteração, poderia tornar o contexto juridicamente relevante.

Assim, se cada fato fosse observado na sua individualidade, verficar-se-ia sua natureza bagatelar. Entretanto, a multi-ocorrência dos mesmos fatos é que torna a questão mais complexa.

Esta modificação no cenário, ocorrida em face da repetição de condutas, impossibilitaria a aplicação do princípio da insignificância.

Importante ressaltar que a "multirreincidência" sob análise pressupõe que as condutas praticadas possuem mesma natureza penal. São fatos que atingem o mesmo bem jurídico.

Alguns exemplos tornam a reiteração cumulativa mais compreensível: um indivíduo que furta, todos os dias, dinheiro do caixa do estabelecimento na qual trabalha. Ainda que furte uma quantia ínfima de dinheiro, certo é que o bem juridicamente protegido pelo artigo 155 do Código Penal (qual seja, o patrimônio da vítima) terá

${ }^{256}$ GOMES, Luiz Flávio. Princípio da Insignificância e outras excludentes de tipicidade, cit., p. 111. 
sofrido manifesta lesão ao final de um determinado lapso temporal e reiteração permanente da prática.

Outro exemplo seria um funcionário público que diariamente apropria-se de um objeto de pequeno valor da repartição pública a que pertence. Ainda que se trate hoje de uma caneta e amanhã de um bloco de notas, o fato é que ao final de um razoável lapso de tempo, o crime de peculato estará caracterizado, porque haveria clara lesão ao patrimônio público protegido pela norma do artigo 312 do Código Penal.

O resultado gerado pela soma de ações passa a não mais ser irrelevante à ordem jurídica, já que haveria, com este somatório de condutas, uma efetiva lesão ao bem (ou bens) juridicamente protegido(s) pela norma penal.

Para o efeito da pena e da aplicação do princípio da insignificância temos que considerar o todo como fato único. Com isso fica refutada a aplicação da doutrina da insignificância quando o agente, mediante reiteradas condutas, acaba lesando seriamente o bem jurídico. ${ }^{257}$

Há, entretanto, quem entenda que a ocorrência de vários fatos insignificantes de mesma natureza não podem ser considerados como um fato único. Se cada um, analisado individualmente, for claramente insignificante, a aplicação do princípio deve ser reconhecida.

Isto porque a repetição de ações configuraria, conforme QUEIROZ, o instituto da continuidade delitiva que obriga o aplicador do Direito a reconhecer que cada conduta, individualmente, é um crime. Assim, se a análise de cada fato demonstrar sua insignificância, o reconhecimento do princípio não pode ser ignorado. ${ }^{258}$

O Superior Tribunal de Justiça, no julgamento do Habeas Corpus $\mathrm{n}^{\mathrm{o}} 221.786$, define taxativamente que não merece ser acolhido o princípio da insignificância quando o indivíduo repete a prática de condutas bagatelares.

O voto chega a mencionar que esta prática — de reiteração da mesma conduta - deve ser interpretada como um meio de vida adotado por determinados indivíduos.

\footnotetext{
${ }^{257}$ Idem, ibidem.

258 QUEIROZ, Paulo de Souza. Princípio da insignificância e maus antecedentes. Disponível no site do autor: http://pauloqueiroz.net/principio-da-insignificancia-e-maus-antecedentes.
} 
Deixa manifesto que o não reconhecimento do princípio, neste caso, se dá por receio de que, caso reconhecido, poderia servir de incentivo para o desrespeito às regras legais:

De fato, a lei seria inócua se fosse tolerada a reiteração do mesmo delito, seguidas vezes, em frações que, isoladamente, não superassem certo valor tido por insignificante, mas o excedesse na soma, sob pena de verdadeiro incentivo ao descumprimento da norma legal, mormente para aqueles que fazem da criminalidade um meio de vida. ${ }^{259}$

Em julgamento do Supremo Tribunal Federal, na Ação Constitucional $n^{\circ}$ 102.088, fica patente o entendimento de que a quantidade de fatos se sobrepõe às características particulares de cada uma das condutas praticadas:

O princípio da insignificância não foi estruturado para resguardar e legitimar constantes condutas desvirtuadas, mas para impedir que desvios de condutas ínfimos, isolados, sejam sancionados pelo direito penal, fazendo-se justiça no caso concreto. Comportamentos contrários à lei penal, mesmo que insignificantes, quando constantes, devido a sua reprovabilidade, perdem a característica de bagatela e devem se submeter ao direito penal. ${ }^{260}$

O cerne da questão, na “multirreincidência cumulativa”, é que em verdade, a punição, quando ocorre, se dá em face da constância dos fatos, e não em face da sua natureza.

O que se pune é a habitualidade do indivíduo que pratica de forma reiterada a mesma conduta, e não cada conduta propriamente.

Aqui, mais importante do que a essência da conduta, é quantas vezes ela é praticada.

\footnotetext{
${ }^{259}$ STJ, Habeas Corpus no 221.786, Quinta Turma, Min Laurita Vaz, j. 07.02.2012.

${ }^{260}$ STF, Habeas Corpus no 102.088, Min. Carmen Lúcia, j. 21.05.2010. Sem grifo no original.
} 


\subsection{A REITERAÇÃO DE DIFERENTES CONDUTAS INSIGNIFICANTES. OS ANTECEDENTES} BAGATELARES

A segunda modalidade, seguindo o rol sugerido por GOMES, é a "multirreincidência ou reiteração não cumulativa". ${ }^{261}$

Aqui, há heterogeneidade dos bens jurídicos que estão sendo lesados por uma pluralidade de condutas praticadas por um mesmo agente.

Se na primeira hipótese estudada há uma junção de ações bagatelares de mesma natureza - que, por resultarem em um conjunto significativo, ferem um único bem jurídico - , nesta segunda hipótese são várias ações bagatelares que atingem diferentes bens jurídicos e inclusive, talvez, diferentes vítimas.

Ademais, as ações não possuem um caráter contínuo como na primeira hipótese: há notória indefinição temporal entre as diferentes condutas. ${ }^{262}$

Aqui, novamente, os exemplos explicitam melhor os elementos teóricos desta modalidade: há "multirreincidência não cumulativa" quando o indivíduo hoje furta de um supermercado um objeto de ínfimo valor, ${ }^{263}$ amanhã lesiona fisicamente outra vítima de forma praticamente imperceptível ${ }^{264}$ e, tempos depois, subtrai algumas canetas da repartição pública na qual trabalha. ${ }^{265}$

Verifica-se que todas as ações citadas, se analisadas individualmente, ferem diferentes bens jurídicos: a primeira ofende o patrimônio, a intermediária lesiona a integridade física e a última o patrimônio público. Ademais, todas as práticas, se consideradas separadamente, podem ser tidas como insignificantes.

O ponto nevrálgico da discussão é que o indivíduo que cometeu uma ação reconhecida como bagatelar não poderia usufruir deste mesmo reconhecimento por infindáveis vezes. Em verdade, é como se houvesse uma perda de primariedade para ações bagatelares.

A indagação central é: a presença destes antecedentes bagatelares deve trazer uma necessidade de reação estatal?

\footnotetext{
${ }^{261}$ GOMES, Luiz Flávio. Princípio da Insignificância e outras excludentes de tipicidade, cit., p. 112.

${ }^{262}$ Idem, ibidem.

${ }^{263}$ Delito previsto no artigo 155 do Código Penal.

${ }^{264}$ Ação formalmente tipificada penalmente no artigo 129 do Código Penal.

${ }^{265}$ Aqui, trata-se do delito previsto no artigo 312 do Código Penal.
} 
A verificação da prática de condutas reiteradas poderia trazer, como diz ARMENTA DEU, uma desvalorização do Direito Penal, que poderia se mostrar fraco caso não reagisse frente a reiteração ? $^{266}$

Ao negar um pedido de reconhecimento da insignificância, o julgado a seguir faz menção a reiteração de condutas delitivas praticadas pelo paciente do Habeas Corpus. Um dos critérios objetivos para incidência do princípio (lesividade mínima da conduta) é ignorado expressamente, e a vida pregressa do indivíduo possui mais importância para a decisão:

1. Comprovada, nos autos, a habitualidade da conduta do paciente no cometimento do ilícito, não há como aplicar, in casu, em seu favor, o princípio da insignificância.

2. Para o reconhecimento do aludido corolário não se deve considerar tão-somente a lesividade mínima da conduta do agente, sendo necessário apreciar outras circunstâncias de cunho subjetivo, especialmente àquelas relacionadas à vida pregressa e ao comportamento social do sujeito ativo, não sendo possível absolvê-lo da imputação descrita na inicial acusatória, se é reincidente, portador de maus antecedentes ou, como na espécie ocorre, reiteradamente pratica o questionado ilícito como ocupação. ${ }^{267}$

Para os que entendem que no Direito Penal não cabe a análise das circunstâncias pessoais em outra situação que não seja na culpabilidade (no momento em que a pena está sendo aplicada), trata-se de algo inadmissível o afastamento da insignificância em face da existência de circunstâncias judiciais desfavoráveis, como a reiteração criminosa. $^{268}$

O princípio da insignificância deve ser reconhecido centrando-se a atenção à lesão que as condutas causam ao bem (ou bens) juridicamente tutelado, sem qualquer análise relativa às características pessoais do indivíduo.

É o que defende MAHMOUD quando afirma que "o princípio da insignificância foi cunhado com o fim de prestigiar o Direito Penal como ultima ratio,

\footnotetext{
${ }^{266}$ ARMENTA DEU, Teresa. Criminalidad de bagatela y princípio de oportunidade, cit., p. 24.

${ }^{267}$ STJ, Habeas Corpus n ${ }^{\circ}$ 33.655, Rel. Ministra Laurita Vaz, DJe 09.08.2004. Sem grifo no original.

268 BARBOSA Jr, Salvador José. FRANZOI, Sandro Marcelo Paris. MORGADO, Nara Cibele Neves. Breves Anotações do Princípio da Insignificância, cit., p. 40.
} 
tendo como foco não o agente, mas, antes, o bem jurídico”, razão pela qual, conforme o autor, não há que se afastar a aplicação do princípio em face da reiteração delitiva. ${ }^{269}$

Como dito por ESTELLITA e LUZ, a junção de condutas objetivamente insignificantes (tal qual o furto de fósforos, como exemplificam) não pode torná-las significativas a ponto de justificar a intervenção estatal "como se a reincidência em um ato insignificante pudesse torná-lo instantaneamente algo relevante para o Direito Penal".

É que os autores chamam de transformação do "princípio da insignificância do ato" em um "princípio da insignificância do próprio autor". ${ }^{270}$

Seguindo este entendimento, não haveria como concordar que a "reiteração não cumulativa" tem o poder de afastar a aplicação do princípio da insignificância, já que o que objetivamente importa, para seu reconhecimento, é apenas o desvalor da ação e do resultado, e não o desvalor da culpabilidade.

Surge, novamente, a questão do caráter objetivo na aplicação do princípio, que se traduz na avaliação dos critérios objetivos para seu reconhecimento: se se entende que a análise a ser feita para aplicar o princípio da insignificância deve estar vinculada à eventual lesão ao bem jurídico, todas as circunstâncias relacionadas diretamente ao indivíduo não poderiam ser sopesadas.

Neste caso, a reiteração de variadas práticas bagatelares, portanto, não poderia ser um óbice para o reconhecimento do princípio. Se cada uma das condutas for materialmente atípica, a insignificância deve ser declarada.

LUISI defende que mesmo a reiteração de condutas delituosas não é fator impeditivo para o reconhecimento do princípio da insignificância. O fato de o sujeito possuir antecedentes não o torna impossibilitado a ser atingido pela aplicação do princípio da insignificância:

Se inexistente a tipicidade, as circunstâncias presentes no contexto fático e a vida pregressa do indiciado não têm o condão de dar matriz criminal ao fato. Uma lesão insignificante a um bem jurídico, mesmo que seja de autoria de um celerado,

\footnotetext{
${ }^{269}$ MAHMOUD, Mohamad Ale Hasan. O princípio da insignificância e o crime continuado, sob uma angulação processual. Boletim IBCCRIM, v. 15, n. 182, jan. 2008. p. 14-15.

${ }^{270}$ ESTELLITA, Heloisa. LUZ, Yuri Corrêa da. Tribunais têm manejado equivocadamente a bagatela. Revista Consultor Jurídico, publicado em 21.08.2011. Disponível em http://www.conjur.com.br/2011-ago21/equivocos-principio-insignificancia-ganham-folego-tribunais.
} 
reincidente na prática dos mais graves delitos, não faz com que ao mesmo se possa atribuir a prática de crime. A vida pregressa, os antecedentes, por mais hediondos que sejam, não podem levar à tipificação criminal de uma conduta. ${ }^{271}$

Se respeitado o direito penal do fato (estudado no capítulo anterior, na excludente de culpabilidade) nesta modalidade de "reiteração cumulativa" que ora se analisa, não se poderia permitir que a prática de mais de uma ação juridicamente insignificante pudesse gerar o impedimento do reconhecimento do princípio sob estudo, o que está demonstrado na decisão proferida pelo Superior Tribunal de Justiça nos autos do Habeas Corpus n 96.929 :

Se o bem tutelado nem mesmo chegou a ser ofendido, nem há relevância na conduta praticada, o princípio da insignificância deve ser aplicado, afastando-se a tipicidade. A aplicação dos princípios da necessariedade e da suficiência afasta a fixação de pena que se mostra excessiva para reprimir conduta irrelevante. Maus antecedentes e reincidência não impedem a aplicação do princípio da bagatela. Ordem concedida para absolver o paciente pelo reconhecimento da atipicidade de sua conduta. ${ }^{272}$

O Supremo Tribunal Federal também profere decisões neste sentido, reconhecendo que a prática de condutas bagatelares anteriores não é óbice para o reconhecimento da insignificância.

Em um destes julgados, o Tribunal reconheceu a aplicação do princípio ainda que tivesse o condenado registro de outras práticas de condutas insignificantes, conforme se demonstra por meio de um trecho da decisão:

Inadequado, por isso, considerar os antecedentes criminais do réu para apreciar se o fato praticado é típico ou não. Ou a lesão provocada tem expressão suficiente para preencher o tipo penal em sua acepção material ou não. ${ }^{273}$

Toda a argumentação desfavorável a rejeição da aplicação do princípio quando há antecedentes, é a mesma utilizada para rechaçar a supremacia da reincidência sobre a insignificância, conforme se verá no item a seguir.

\footnotetext{
${ }^{271}$ LUISI, Luiz. O princípio da insignificância e o pretório excelso, cit. Sem grifo no original.

${ }^{272}$ STJ, Habeas Corpus no 96.929, Min. Jane Silva, Sexta Turma, j. 08.04.2008. Sem grifo no original.

${ }^{273}$ STF, RE 550.761, Min. Menezes Direito, Primeira Turma, j. 27.11.2007.
} 


\subsection{FATO INSIGNIFICANTE COMETIDO POR UM INDIVÍDUO REINCIDENTE}

A terceira modalidade a ser estudada é a que trata do cometimento de uma conduta insignificante, porém realizada por agente reincidente.

O ponto problemático passa a ser a prévia existência de uma condenação definitiva pela prática de conduta materialmente típica, que vem a barrar a aplicação do princípio da insignificância em face do indivíduo ser considerado tecnicamente reincidente.

Em realidade, a discussão que surge em relação à presente modalidade é equivalente à anterior discussão sobre a "reiteração não cumulativa": torna-se a questionar a legitimidade de aplicação do princípio da insignificância em favor de indivíduo que esteja maculado pela reiteração.

Dois são os entendimentos a respeito.

O primeiro defende que é impossível desconsiderar que o agente que pratica a conduta em tese insignificante já recebeu condenação por outra prática, o que resultaria em não poder ver reconhecida a aplicação do princípio em estudo.

Uma das argumentações utilizadas é a de que o reconhecimento acabaria por causar um verdadeiro incentivo à prática de outras condutas insignificantes, ou mesmo criminosas.

Apesar de tratar-se de critério subjetivo, a reincidência deve ser excepcionada da regra para análise do princípio da insignificância, pois não está sujeita a interpretações doutrinárias e jurisprudenciais ou a análises discricionárias. O criminoso reincidente, como é o caso do ora Paciente, apresenta comportamento reprovável, e sua conduta deve ser considerada materialmente típica. ${ }^{274}$

Para justificar este entendimento, utiliza-se $\mathrm{o}$ fundamento de que $\mathrm{o}$ fato analisado não pode ser considerado atípico, em face da reiteração criminosa preexistente. É como se a característica pessoal do agente pudesse alterar a natureza de tipicidade de uma conduta, transformando-se sua atipicidade em tipicidade:

${ }^{274}$ STF, Habeas Corpus no 109.739, Primeira Turma, Min. Cármen Lúcia, j. 13.12.2011. 
(...) 2. Hipótese de furto, na qual não se observa a irrelevância do fato, tendo em vista a reincidência do agente, situação que demonstra a sua efetiva periculosidade social, exigindo-se a atuação por parte do Estado. 3. O comportamento versado nos autos se amolda tanto à tipicidade formal e subjetiva, quanto à tipicidade material, que consiste na relevância jurídico-penal da ação, visto que restou destacado que o furto em questão não representa fato isolado na vida do paciente, porquanto fora anteriormente condenado por roubo circunstanciado, impondo-se, portanto, a incidência da norma penal de modo a coibir a reiteração criminosa. 4. Habeas corpus denegado. $^{275}$

\subsubsection{Crítica: a reincidência como óbice ao reconhecimento da insignificância}

Há um entendimento diverso do apresentado, que entende que a conduta deve ser analisada isoladamente, e se preencher os critérios objetivos para a aplicação do princípio da insignificância, este deve ser reconhecido independentemente do indivíduo ser considerado reincidente. ${ }^{276}$

Tal erro teórico, se levado a cabo, pode ser muito perigoso, porque acabaria por afastar a insignificância quando o acusador fosse, por exemplo, reincidente, ainda que sua conduta seja absolutamente irrelevante, se vista sob um aspecto objetivo."277

Esta "mistura" entre o instituto da reincidência e a insignificância pode ferir o princípio da proporcionalidade, o que GONÇAVES explica por meio de um esclarecedor exemplo. $^{278}$

Um indivíduo primeiro furta um maço de cigarro e, tempos depois, um valioso relógio. Pode-se imaginar que ele terá a primeira conduta reconhecida como

\footnotetext{
${ }^{275}$ STJ, Habeas Corpus no 217854, Quinta Turma, Min. Jorge Mussi, j. 07.02.2012.

${ }^{276} \mathrm{O}$ instituto da reincidência é muito contestado no meio jurídico e comum é a crítica a seu respeito, havendo forte corrente doutrinária que defende sua inconstitucionalidade. Entretanto, o presente estudo não se dedica ao debate a respeito da legitimidade do instituto da reincidência. Limita-se, portanto, a analisar sua relação com o princípio da insignificância, este sim o cerne do presente trabalho.

277 LUZ, Yuri Corrêa da. Princípio da Insignificância em matéria penal: entre aceitação ampla e aplicação problemática, cit., p. 215.

278 GONÇALVES, Henrique de Almeida Freire. Reincidência penal e princípio da insignificância. Disponível em http://www.ibccrim.org.br.
} 
insignificante, e pelo cometimento da segunda conduta será condenado pelo crime de furto.

Outro indivíduo comete o furto de um valioso relógio e, mais adiante, furta um maço de cigarro (situação, portanto, inversa à primeira). Neste caso, ele será condenado pelo furto do bem valioso, e com a prática do segundo furto, será considerado reincidente. ${ }^{279}$ Assim, caso se entendesse que a reincidência impossibilita o reconhecimento do princípio da insignificância, não só haveria condenação pelo furto do maço de cigarro, como haveria o aumento da pena em face de ser reincidente.

GONÇALVES alerta para a absoluta desproporcionalidade existente entre os resultados obtidos em condutas idênticas, que só se diferenciam no que toca à questão temporal do cometimento dos crimes referidos. Os crimes cometidos são os mesmos. O que há de distinto é a ordem em que ocorreram. Os resultados por eles produzidos, entretanto, são consideravelmente diversos.

Nestes casos, a conduta bagatelar não só não é reconhecida como tal, como pode gerar uma punição que, na verdade, é fruto ainda da punição anterior. Esta é, aliás, a mais forte característica da reincidência: ela pune duas vezes a mesma conduta. ${ }^{280}$

É por isso que, conforme CARVALHO, todos os direitos que forem obstaculizados pela reincidência (e aqui vale o direito a se ter reconhecida a insignificância de uma conduta) representam ofensa ao princípio do ne bis in idem, que se traduz na vedação à dupla valoração de uma mesma circunstância. ${ }^{281}$

\subsection{2. a incompatibilidade do direito penal do autor com o Direito Penal Mínimo}

O reconhecimento da reincidência como causa para a não aplicação do princípio da insignificância representa a já mencionada supremacia do direito penal do autor, onde as características pessoais do agente são priorizadas em detrimento das características objetivas do fato.

\footnotetext{
${ }^{279}$ Considera-se aqui que a condenação pelo furto do relógio transitou em julgado e o novo furto ocorreu menos de 05 anos depois do primeiro.

${ }^{280}$ CARVALHO, Salo. Reincidência e Antecedentes Criminais: Abordagem Crítica desde o marco garantista. Revista da Ajuris. Porto Alegre: Ajuris, 1999, vol. 76, p. 738-755.

${ }^{281}$ Idem, ibidem.
} 
Esta é a maior crítica feita pela corrente que entende que o fato de ser o agente reincidente não impossibilita o reconhecimento da insignificância de uma conduta por ele praticada.

Para sua aplicação não contam os dados pessoais do agente, e sim as peculiaridades do caso concreto. O fato é insignificante (ou não) independentemente das condições pessoais do agente (maus antecedentes, reincidência etc). Dessa forma é que o juiz deve analisar o fato. ${ }^{282}$

Se, conforme QUEIROZ, o que está sendo discutido é o fato e não as características particulares do agente, o principio deve ser aplicado, já que está, no entendimento do autor, vinculado à excludente de tipicidade (onde o juízo sobre o autor não é considerado).

A reincidência está relacionada estritamente com a culpabilidade analisada somente na fase de aplicação penal: "Enfim, por traduzir um problema de tipicidade, $e$ não de individualização judicial da pena, o princípio da insignificância deve ser reconhecido independentemente da existência de maus antecedentes, reincidência ou continuidade delitiva."283

O Direito Penal Mínimo, como já analisado no primeiro capítulo, afasta a análise das condições pessoais do indivíduo e se preocupa exclusivamente com o fato por ele praticado. "A repressão penal somente pode voltar-se para a conduta do homem, jamais para aquilo que ele é.” 284

Por esta razão é que o modelo penal de mínima intervenção não é compatível nem com a excludente de culpabilidade como consequência da aplicação do princípio, tampouco com o efeito negativo que a reincidência pode causar no reconhecimento da insignificância.

REALE Jr explica que o direito penal do fato "exclui, também, que a punição volte-se contra tipo criminológico de autor ou tipo normativo de autor, dando ênfase às características pessoais ou subjetivas." 285

\footnotetext{
${ }^{282}$ GOMES, Luiz Flávio. Princípio da Insignificância e outras excludentes de tipicidade, cit., p. 114.

283 QUEIROZ, Paulo de Souza. Princípio da insignificância e maus antecedentes. Disponível no site do autor: http://pauloqueiroz.net/principio-da-insignificancia-e-maus-antecedentes.

${ }^{284}$ CABETTE, Eduardo Luiz Santos. Informativo n. 489, cit., p. 168.

${ }^{285}$ REALE JÚNIOR, Miguel. Instituições de Direito Penal. RJ: Forense, 2009, p. 34.
} 
Por estar tal modelo de Direito Penal relacionado ao princípio da legalidade e, também, aos princípios da proporcionalidade, ultima ratio e fragmentariedade, ${ }^{286}$ somente é compatível com os preceitos do direito penal do fato, que rejeita qualquer análise sobre as circunstâncias do indivíduo fora do momento de aplicação da pena (onde as circunstâncias do artigo 59 do Código Penal são aferidas).

Ao analisar uma decisão do Superior Tribunal de Justiça (proferida no Habeas Corpus $\mathrm{n}^{\mathrm{o}} 150.236^{287}$ ), CABETTE critica o afastamento da insignificância por ser o paciente reincidente.

O julgado se refere ao indivíduo como "aquele que faz da conduta criminosa um meio de vida". Esta menção, conforme condena o autor, deixa manifesta a intenção de punir infratores da lei que cometem condutas criminosas (mesmo que insignificantes) no lugar de analisar condutas.

É como se a reiteração pudesse tornar típicos fatos que não são, já que insignificantes. O que inicialmente se caracteriza pela ausência material de tipicidade, passa a ser considerado típico única e exclusivamente em função da reiteração de condutas. "E desse caos surge uma espécie de tipicidade por acumulação de condutas atípicas, que pode ter consequências extremamente funestas no campo prático e na própria coerência da dogmática penal." 288

O que se verifica é que não se analisa as circunstâncias da conduta praticada. Estes elementos objetivos, que delimitam a tipicidade, são ignorados em prol da análise do indivíduo (tudo em conformidade ao que já foi analisado e criticado quando da análise da excludente de culpabilidade, no capítulo anterior). E a ocorrência da reincidência recebe mais importância do que a insignificância do delito:

o que ele fez não teria relevância para o direito penal caso fosse um cidadão 'do bem', ao invés de um 'inimigo da sociedade'. É a partir dessa lógica vetusta e infeliz que se escolhe punir ou não fatos idênticos, com a mesma gravidade, a depender da vida pregressa do agente ser ou não merecedora de censura. ${ }^{289}$

\footnotetext{
${ }^{286}$ CABETTE, Eduardo Luiz Santos. Informativo n. 489, cit., p. 170.

${ }^{287}$ STJ, Habeas Corpus no 150.236, Min. Laurita Vaz, j. 06.12.2011.

${ }^{288}$ CABETTE, Eduardo Luiz Santos. Informativo n. 489, cit., p. 170. Sem grifo no original.

289 GONÇALVES, Henrique de Almeida Freire. Reincidência penal e princípio da insignificância. Disponível em http://www.ibccrim.org.br.
} 
Considerar a reincidência para obstar o reconhecimento da insignificância é, pois, a verdadeira tradução da aplicação do direito penal do autor. É trazer para o juízo de tipicidade a análise de uma circunstância que deve ser apreciada na culpabilidade. E, conforme já defendido no presente trabalho, o juízo de culpabilidade não tem relação com a aplicação do princípio da insignificância.

Parte da jurisprudência defende esta corrente, tendo por fundamentação central o caráter objetivo da aplicação do princípio da insignificância, que determina seja a atipicidade reconhecida isoladamente, sem a menção às circunstâncias pessoais do agente, já que o relevante é a análise do fato em si, para que se verifique se é ou não insignificante.

O Supremo Tribunal Federal, cujo entendimento não é pacífico em relação à aceitação do princípio nos casos em que o indivíduo é reincidente, já manifestou, por meio de alguns votos, a necessidade de se dissociar o direito penal do autor do direito penal do fato.

Esta tendência se verifica nos julgados em que se reconhece que a aplicação da insignificância traz consigo a exclusão da tipicidade (que carrega com ela o respeito ao direito penal do fato):

Não cabem, para a averiguação da tipicidade da conduta, ponderações sobre as circunstâncias pessoais do agente. Se determinado fato não é típico, passa a ser irrelevante se foi praticado por reincidente contumaz ou por alguém que não tenha antecedentes criminais, pois não há crime!

Assim, se a análise concreta do fato em exame levar a conclusão de que a lesão ao bem jurídico é insignificante, a atipicidade do fato leva à inexistência do crime, pouco importando as circunstâncias pessoais do agente. ${ }^{290}$

Para o modelo de Direito que preceitua a intervenção penal mínima e que não traz o indivíduo para o centro da razão de punir - e sim os fatos por ele cometidos e a proteção aos bens jurídicos protegidos - o sistema penal não deve ser “um instrumento de

\footnotetext{
${ }^{290}$ Trecho da decisão liminar favorável concedida nos autos do Habeas Corpus nº 93.393, do Supremo Tribunal Federal, sob relatoria do Ministro Cezar Peluso, da Segunda Turma, julgado em 14.04.2009.
} 
salvação ou depuração de quem quer que seja, nem como um meio de moldar personalidades, condução de vida ou caráter.,"291

Para a aplicação do princípio em estudo, basta, portanto, olhar para os elementos objetivos que compõem a tipicidade penal, "afastando considerações sobre os antecedentes do agente, seu passado, sua periculosidade, entre outras circunstâncias pessoais pertencentes exclusivamente ao juízo de culpabilidade penal. ${ }^{, 292}$

\subsection{A HABITUALIDADE: OS CRIMES DE MASSA}

Outra problemática situação que envolve a incidência do princípio da insignificância diz respeito aos chamados crimes de massa.

Nos itens anteriores deste capítulo, analisou-se um rol de situações que envolviam várias ações, porém cometidas por um único indivíduo.

Ao se analisar os crimes de massa, o cenário se modifica. São várias ações cometidas por vários indivíduos.

A questão nebulosa na presente discussão é que, ainda que cada uma destas ações individualmente possa ser insignificante, o conjunto final resultante poderia revelar uma ofensa ao bem tutelado. A verificação individualizada de cada um dos fatos revela seu caráter bagatelar. Porém, se tais fatos forem cometidos de forma massificada, acaba por lesionar o bem jurídico que a norma penal visa a proteger.

Se inúmeros indivíduos furtam objetos de pequeno valor de uma rede de supermercado, por exemplo, o prejuízo final da soma destas condutas poderia ser muito significativo. Porém, olhando individualmente para cada uma destas condutas, evidente é seu caráter bagatelar.

\footnotetext{
${ }^{291}$ KATTAH, Marina. O princípio da insignificância e sua relação com o moderado direito penal do fato e com o funcionamento teleológico de Roxin, cit., p. 245.

${ }^{292}$ ESTELLITA, Heloisa. LUZ, Yuri Corrêa da. Tribunais têm manejado equivocadamente a bagatela. Revista Consultor Jurídico, publicado em 21.08.2011. Disponível em http://www.conjur.com.br/2011-ago21/equivocos-principio-insignificancia-ganham-folego-tribunais.
} 
ARMENTA DEU alerta para essa forma massificada de criminalidade, referindo que sua incidência pode acarretar em uma fragilização do Direito Penal. ${ }^{293}$

LOPES entende que esta situação pode ferir o princípio da igualdade: " $a$ proteção de interesses de vítimas ou a punição de autores segmentarizados dentro do Estado pode gerar - ou simplesmente desvendar - um processo discriminatório de cunho social, étnico, econômico ou de outra monta, qualquer um comprometedor do desenvolvimento da harmonia social que deve se desenvolver dentro do Estado."294

Se a análise recair única e exclusivamente sobre o prejuízo que as vítimas podem obter, a conclusão é a de que, dado o alto montante monetário que esta habitualidade pode gerar, o princípio da insignificância jamais poderia ser aplicado.

E, vale ressaltar, o Poder Judiciário não tem como julgar os crimes de massa na integralidade que o compõe. Cada conduta necessita ser analisada individualmente pelo aplicador do Direito. Não há como julgar tais crimes sem individualizar a conduta de cada um dos indivíduos que deles participaram, já que ao Direito Penal é vedada a acusação genérica.

Diante da flagrante bagatela das condutas, caberia ao julgador reconhecer a incidência do princípio da insignificância ou, considerando a habitualidade de condutas de mesma natureza, afastar o principio exatamente para punir esta habitualidade, que é praticada por um número significativo de pessoas.

Essas situações, conquanto possam ser reclamadas de comportamentos anti-sociais e o são efetivamente - não dispõem de uma grandeza simbólica para penetrar no sistema das repressões máximas da ordem estatal, quedando como situações ainda que não socialmente adequadas, pelo menos socialmente toleradas na organização social - uma espécie de comportamento previsível, embora não desejado, sem que seja, no entanto, merecedor do repúdio extremo. ${ }^{295}$

Não há como ignorar a existência dos delitos de massa. Não só existem como podem efetivamente causar um prejuízo considerável.

\footnotetext{
${ }^{293}$ ARMENTA DEU, Teresa. Criminalidad de bagatela y princípio de oportunidade, cit., p. 24.

${ }^{294}$ LOPES, Maurício Antônio Ribeiro. Princípio da Insignificância no Direito Penal, cit., p. 145.

${ }^{295}$ LOPES, Maurício Antônio Ribeiro. Princípio da Insignificância no Direito Penal, cit., p. 146.
} 
Entretanto, o que também não pode ser ignorado é o caráter irrisório de cada uma das condutas praticadas. Se o que se prega é exatamente a supremacia de um direito penal focado única e exclusivamente nos fatos, não haveria como ignorar esta natureza bagatelar.

Punir o indivíduo autor da prática insignificante somente porque a conduta por ele praticada não é a única que fere determinado bem jurídico e está enquadrada na chamada criminalidade de massa, não parece ser o caminho mais compatível com a mínima intervenção penal.

BECHARA, que trata do tema fazendo menção aos delitos cumulativos (que estão associados aos tipos penais que protegem bens jurídicos coletivos ou difusos), explica que a ideia de um direito penal garantista é lesada na medida em que " $a$ imputação de fato ao agente depende não de sua própria conduta, mas sim de contribuições alheias." 296

Refere a autora que se trata de uma "atitude equivocada" reconhecer os delitos de acumulação quando na verdade cada conduta individualizada não representa ofensa ao bem jurídico, "na medida em que aqui não se está mais diante de um delito cumulativo, $e$ sim de mera causalidade cumulativa." 297

Considerando que, conforme já referido, os delitos de massa não podem ser julgados em uma única ação penal, seria necessário que a intervenção penal operasse contra cada um dos indivíduos, o que, conforme BECHARA, causaria inevitável flexibilização (e com isso, consequente ofensa) aos princípios fundamentais:

Na verdade, o debate acerca dos danos cumulativos é, antes de tudo uma questão de política criminal. Caso fosse possível legitimar os delitos de cumulação, elegendo-se tal modelo de intervenção penal na esfera supraindividual, haveria que se flexibilizar nesse âmbito institutos e princípios fundamentais, a começar pela função do direito penal de proteção de bens jurídicos. ${ }^{298}$

\footnotetext{
${ }^{296}$ BECHARA, Ana Elisa Liberatore Silva. Da teoria do bem jurídico como critério de legitimidade do direito penal. Tese de Livre-Docência apresentada à Faculdade de Direito da USP, São Paulo, 2010, p. 262.

${ }^{297}$ Idem, ibidem, p. 263.

${ }^{298}$ Idem, ibidem, p. 264.
} 


\subsection{A APLICAÇÃO NOS CRIMES VIOLENTOS OU COM GRAVE AMEAÇA}

Além da problemática que envolve o reconhecimento da insignificância quando a reincidência ou os antecedentes estão presentes, há outros pontos nevrálgicos que envolvem a aplicação do princípio.

Parte da doutrina e da jurisprudência, por exemplo, defende que é vedada sua aplicação quando se trata de determinados tipos penais.

O crime de homicídio (mesmo que o homicídio tentado) e de estupro, por exemplo, não estariam inseridos na possibilidade de aplicação do princípio da insignificância por serem tipos penais que envolvem violência ou grave ameaça e que atentam contra a vida. A justificativa é de que a lesão ao bem jurídico é incontestavelmente clara e de dimensões muito expressivas. ${ }^{299}$

O Superior Tribunal de Justiça, por exemplo, no julgamento do Recurso Especial $n^{\circ}$ 468.998, pela Quinta Turma (com relatoria do Ministro Arnaldo Esteves Lima), decidiu que quando há tutela à liberdade e integridade da pessoa, a insignificância da conduta não poderá ser reconhecida. 300

FELIPETO entende que quando há ofensa a bem jurídico que envolva atentado à incolumidade física ou a liberdade individual, a aplicação do princípio sob estudo deve ser afastada. Defende que não há como reconhecer a conduta como insignificante quando atinge tais bens jurídicos. ${ }^{301}$

Entendimento doutrinário contrário conta com a voz de QUEIROZ, que defende que mesmo nesses casos o reconhecimento da insignificância pode ser aplicado, em respeito ao princípio da proporcionalidade. ${ }^{302}$

$\mathrm{O}$ argumento é o de que se um delito com violência ou grave ameaça protege o bem jurídico "liberdade individual", por exemplo, e este bem não for ofendido, não há como subsistir o crime previsto no tipo penal, como explica MARCHI JR. Se a aplicação

\footnotetext{
${ }^{299}$ COELHO, Edilhermes Marques. O conceito de crime e a aplicação do princípio da insignificância, cit., p. 67.

${ }^{300}$ STJ, REsp no 468.998, Quinta Turma, Min. Arnaldo Esteves Lima, DJe 17.08.2006.

${ }^{301}$ FELIPETO, Rogério. Princípio da insignificância e delito complexo. Boletim do Instituto de Ciências Penais-ICP, Belo Horizonte, v. 3, n. 32, p.3-4, dez. 2002, p. 3.

${ }^{302}$ QUEIROZ, Paulo de Souza. Direito penal: parte geral, cit., p. 60-61.
} 
do princípio se dá pela excludente de tipicidade, e o fato não preenche os elementos da tipicidade material, insignificante é a conduta. ${ }^{303}$

Há outro fundamento a favor da aplicação do princípio nos crimes que envolvem violência ou grave ameaça: não se está a discutir se o bem jurídico é relevante ou irrelevante.

Ninguém discorda que, no crime de roubo, os bens tutelados são de extrema relevância (patrimônio e integridade física ou liberdade individual). Ter sido tutelado pelo tipo penal já é a demonstração suficiente de que é um bem relevante.

O que importa na presente discussão é saber se a lesão ao bem é significante ou não. Se não for, a insignificância pode ser reconhecida. ${ }^{304}$

A questão gira em torno das circunstâncias objetivas que indicam tipicidade ou atipicidade, e não em torno da importância dos bens penalmente tutelados.

A análise da jurisprudência manifesta a tendência de rejeitar o reconhecimento do princípio da insignificância quando há violência ou grave ameaça na conduta do agente.

Conforme a pesquisa de BOTTINI, de todos os julgados analisados que envolviam o crime de roubo (previsto no artigo 157 do Código Penal e que é praticado com violência ou grave ameaça), em nenhum houve o reconhecimento do principio. ${ }^{305}$

Ainda na referida pesquisa, de todos os julgados analisados que envolviam pedido de reconhecimento do princípio da insignificância, verificou-se que a violência ou grave ameaça foi responsável por $23,3 \%$ das decisões de rejeição de sua aplicação. ${ }^{306}$

\footnotetext{
${ }^{303}$ MARCHI JÚNIOR, Antônio de Padova. O princípio da insignificância e o crime de roubo. Boletim do Instituto de Ciências Penais, $\mathrm{n}^{\mathrm{o}}$ 13, p. 12.

${ }^{304}$ OLIVEIRA, Luciano Moreira de; Albuquerque, Marcelo Schirmer. Aplicabilidade do princípio da insignificância aos crimes complexos, cit., p. 64.

${ }^{305}$ BOTTINI, Pierpaolo Cruz. O Princípio da Insignificância nos crimes contra o patrimônio e contra a ordem econômica: análise das decisões do Supremo Tribunal Federal, cit., p. 16.

${ }^{306}$ Vide tabela n. 6, in BOTTINI, Pierpaolo Cruz . O Princípio da Insignificância nos crimes contra o patrimônio e contra a ordem econômica: análise das decisões do Supremo Tribunal Federal, cit., p. 19.
} 


\subsection{A APLICAÇÃO NOS CRIMES COMPLEXOS}

Ainda dentro das situações que apresentam grande complexidade no que se refere à aplicação do princípio da insignificância, encontra-se a problemática que envolve os crimes complexos.

O crime complexo é definido como o tipo penal que apresenta elementos constitutivos de dois outros tipos originários. Há uma junção dos elementos que faz com que o crime complexo contenha em sua estrutura as características de tipos penais simples. ${ }^{307}$

A ocorrência de um crime complexo, portanto, resulta na ofensa simultânea a dois bens penalmente tutelados.

O tipo penal previsto no artigo 157 do Código Penal é um clássico exemplo. O crime de roubo é uma junção dos crimes de furto (artigo 155 do mesmo diploma) e do crime de lesão corporal (artigo 129).

Neste exemplo, tanto o patrimônio quanto a integridade física (ou liberdade individual) estão sendo protegidos em um mesmo tipo penal.

A questão é: pode haver reconhecimento do princípio da insignificância quando a conduta praticada é um crime complexo?

OLIVEIRA e ALBUQUERQUE ${ }^{308}$ fazem alusão a uma possibilidade de aplicação do princípio em estudo, que é a de analisar separadamente cada bem jurídico protegido pelo tipo penal complexo. Isto porque a insignificância pode ser reconhecida para um e não para o outro.

Embora os autores mencionem esta possibilidade de aplicação do princípio, revelam, ao final do seu texto, que são contra esta prática, conforme será mencionado a seguir.

Para utilizar o mesmo exemplo, poderia se aplicar tal regra no crime de roubo quando a insignificância fosse arguida em face do irrisório valor da coisa subtraída.

\footnotetext{
${ }^{307}$ GOMES, Mariângela Gama de Magalhães. Bases para uma Teoria Geral da Parte Especial do Direito Penal, cit., p. 264.

${ }^{308}$ OLIVEIRA, Luciano Moreira de; ALBUQUERQUE, Marcelo Schirmer. Aplicabilidade do princípio da insignificância aos crimes complexos. De Jure: Revista Jurídica do Ministério Público do Estado de Minas Gerais, Belo Horizonte, n. 4, p.59-66, jan./jun. 2002, p. 63.
} 
Assim, a insignificância poderia ser reconhecida em relação à irrisória ofensa ao bem penalmente protegido "patrimônio", referente ao crime de furto. Não haveria o reconhecimento da insignificância, entretanto, em relação à lesão ao bem jurídico "integridade física" ou "liberdade individual".

Para poder ser reconhecida a aplicação do princípio da insignificância, o crime complexo teria que se decompor em outros dois tipos penais, que deveriam ser analisados isoladamente:

há uma decomposição do delito em furto e lesão corporal ou ameaça, acarretando a punição do agente apenas por esses últimos, em virtude da insignificância da lesão patrimonial. $^{309}$

Esta possibilidade é defendida por QUEIROZ que, ao se referir a este exemplo de crime complexo, defende que em conformidade com o princípio da proporcionalidade não há como condenar o indivíduo a uma pena por ofensa a um bem jurídico que não foi agredido. Defende, assim, a punição apenas e tão somente em relação ao bem jurídico que sofreu lesão. ${ }^{310}$

Pensamento semelhante é apresentado por LUZ, que o explica por meio de um exemplo. ${ }^{311}$ Um militar que é acusado pelo crime previsto no artigo 290 do Código Penal Militar (posse de drogas), tem sua conduta classificada como ofensiva tanto à saúde pública quanto às instituições militares. São dois bens jurídicos em tese ofendidos.

Entretanto, se comprovado que o militar portava ínfima quantidade da substância entorpecente, a saúde pública não pode ter sido minimamente lesada.

Sugere o autor que poder-se-ia reconhecer o princípio da insignificância no que toca este bem jurídico. Caso se entenda que as instituições militares foram efetivamente ofendidas, poder-se-ia desclassificar o delito de posse de drogas para o delito de desobediência (previsto no artigo 301 do mesmo Código), que possui pena mais branda. $^{312}$

\footnotetext{
${ }^{309}$ Idem, ibidem.

${ }^{310}$ QUEIROZ, Paulo de Souza. Direito penal: parte geral, cit., p. 61.

311 LUZ, Yuri Corrêa da. Princípio da Insignificância em matéria penal: entre aceitação ampla e aplicação problemática, cit., p. 222.

${ }^{312} \mathrm{O}$ exemplo hipotético do autor pode ser visto em um julgado do Supremo Tribunal Federal (STF, Habeas Corpus $\mathrm{n}^{\mathbf{0}}$ 90.125, Segunda Turma, Min. Ellen Gracie, j. 24.06.2008), onde se discute o
} 
O exemplo hipotético apresentado por LUZ é semelhante a um julgado do Supremo Tribunal Federal. Nele, se discute a possibilidade de conceder ordem de Habeas Corpus para um militar acusado pelo crime de peculato, porque teria se apropriado de um fogão pertencente à Unidade Militar.

A questão gira em torno do fato de que a conduta praticada pelo paciente não teria ferido apenas o bem jurídico de cunho patrimonial. Teria, igualmente, ofendido a administração militar, "o que faz a conduta do paciente ultrapassar os domínios da singela patrimonialidade pública" ${ }^{313}$, demonstrando-se, com isto, que se está diante de uma discussão que envolve um crime complexo.

Mas a aceitação desta regra não é unanimidade.

Para FELIPETO, o crime complexo é um tipo penal único e indissolúvel, não sendo possível fracioná-lo em dois outros tipos penais distintos. ${ }^{314}$ A opção do legislador foi inserir um tipo penal específico, complexo, e esta característica faz parte do seu núcleo.

Entende, pois, que por mais que seja insignificante a lesão causada a um dos bens juridicamente tutelados pelo tipo complexo, se o outro bem foi lesionado, o princípio da insignificância deve ser afastado.

OLIVEIRA e ALBUQUERQUE, conforme já referido, possuem entendimento equivalente, ressaltando que o tipo completo não pode ser desmembrado, já que é uma "unidade autônoma" e, caso desmembrado, acabaria gerando o instituto do concurso material, perdendo a essência de tipo complexo. ${ }^{315}$

Esta impossibilidade, segundo os autores, não impede que o princípio seja reconhecido sob outras circunstâncias. Caso todos os bens jurídicos tutelados pelo crime complexo não sejam ofendidos, a insignificância pode ser reconhecida. ${ }^{316}$

Assim, seria tal princípio respeitado sem que houvesse a necessidade de cindir um tipo penal que já nasceu complexo, e assim deve permanecer.

\footnotetext{
trancamento de ação penal em favor de um militar que respondia ação penal por uso de substância ilícita entorpecente. Decidiram os julgadores aplicar o princípio da insignificância.

${ }^{313}$ STF, Habeas Corpus no 87.478, Primeira Turma, Min. Eros Grau, j. 29.08.2006.

${ }^{314}$ FELIPETO, Rogério. Princípio da insignificância e delito complexo, cit.

315 OLIVEIRA, Luciano Moreira de; Albuquerque, Marcelo Schirmer. Aplicabilidade do principio da insignificância aos crimes complexos, cit., p. 64.

${ }^{316}$ Idem, ibidem.
} 


\section{Notas Conclusivas}

O trabalho não possui qualquer pretensão de esgotar a discussão acerca das matérias abordadas. Delimitou-se o tema sobre o princípio da insignificância com a consciência de que muitas questões importantes ficaram à margem do debate.

Dentro dessa delimitação, foi possível construir determinadas conclusões.

1. A existência de condutas criminosas sempre existiu e nenhum modelo de Direito Penal conseguirá extingui-las. Entretanto, o modelo pregado pelo Direito Penal de mínima intervenção rejeita a possibilidade de abraçar todas as condutas que se entendam sejam criminosas. Deseja preocupar-se somente com aquelas que imprescindivelmente precisam ser analisadas pela via penal, já que todos os outros ramos do Direito não são suficientes.

2. Este modelo não é permissivo com a prática de crimes. É apenas compatível com os preceitos constitucionais e, exatamente por respeitar os princípios e garantias da Carta Maior - a quem, aliás, é subordinado - é que rechaça um modelo de Direito Penal máximo e autoritário.

3. O que fortalece o Direito Penal é exatamente seu caráter subsidiário em relação aos demais ramos do Direito. Se respeitada sua natureza de ultima ratio e for ele utilizado apenas quando sua força extrema se mostrar necessária, estar-se-á diante de uma atuação penal verdadeiramente eficaz.

4. Como consequência, ele tem o papel de proteger os mais valiosos bens jurídicos, que são o produto dos desejos, interesses e pensamentos da sociedade, ainda que muitas vezes sejam eleitos por grupos dominantes. 
5. O princípio da insignificância atua como uma via redutora do Direito Penal, e tem por finalidade não permitir que nele permaneçam sendo discutidas condutas que não venham a ferir minimamente os bens penalmente protegidos.

6. O princípio da insignificância exerce o papel de verdadeiro vetor interpretativo para aplicação nos casos concretos, interpretando as normas penais a fim de verificar as limitações de atuação das mesmas.

7. Foi possível concluir que se por um lado não há dúvida em relação à legitimidade de atuação do principio no Direito Penal, por outro ainda é complexa a dinâmica que envolve seus critérios de aplicação. A inexistência de previsão expressa fez com que a jurisprudência fosse a pioneira, no Brasil, a mencionar alguns critérios para seu reconhecimento.

8. Se um dos critérios passa a ser o valor monetário que envolve a prática de determinadas condutas, ou melhor, o resultado de determinadas condutas, então deve-se entender que o princípio da insignificância, em determinados casos, estará sendo debatido dentro da esfera processual e não na esfera penal. Se vinculado estiver ao princípio da oportunidade, seus critérios de aplicação são outros, e o desvalor da ação passa a não ter mais o mesmo sentido.

9. O reconhecimento de que a conduta é insignificante gera consequências que, tanto para a doutrina quanto para a jurisprudência, podem ser diversas, como a excludente de tipicidade, ilicitude ou culpabilidade.

10. Foi possível concluir que o princípio da insignificância tem relação com a excludente de tipicidade. Defende-se a idéia de que, dessa forma, está a "corrigir" a "deficiente" atuação do legislador, que não consegue prever ante post todas as situações 
que poderão ocorrer, o que traduz a supremacia da tipicidade material em face da meramente formal.

11. Conclui-se que este modelo, de exclusão da tipicidade, é o que se ampara em critérios apenas objetivos, sem se voltar para as características pessoais do indivíduo, focando apenas no fato que está sendo analisado. Assim, se mostra em plena conformidade com os preceitos do Direito Penal minimamente intervencionista, que rejeita a supremacia do direito penal do autor e prega que não cabe ao Direito Penal tratar de condutas que não tenham efetivamente ofendido bens jurídicos. A excludente de tipicidade material como consequência da aplicação do princípio demonstra que este é, claramente, um meio redutor da repressão penal.

12. A mínima intervenção penal, amparada nos preceitos constitucionais, afasta qualquer possibilidade de que se coloque o indivíduo no centro do debate. Por esta razão, criticou-se a excludente de culpabilidade como consequência do princípio, exatamente porque se verificou que nela as circunstâncias pessoais do agente são o ponto de discussão, e não o fato por ele cometido.

13. Nesta mesma linha de entendimento, circunstâncias como antecedentes e reincidência não podem obstar a aplicação do princípio da insignificância. Ambas estão dentro de um contexto voltado (tal qual a excludente de culpabilidade) ao estudo do perfil do indivíduo, em clara adesão ao direito penal do autor, absolutamente incompatível com o Direito Penal Mínimo. E conclui-se que a aplicação do princípio da insignificância não deve estar atrelado a tais circunstâncias, não sendo um óbice que o indivíduo possua antecedentes ou seja reincidente.

14. As mais variadas formas de aplicação do princípio (aceito em determinados casos que envolvem violência e crimes complexos, negado em outros) demonstra que não há um consenso sobre como deve efetivamente incidir. O que restou concluído ao final do presente trabalho é que o principio não pode ficar subordinado ao entendimento pessoal de cada um dos aplicadores do Direito. Um mínimo de 
uniformização precisa ocorrer, a fim de que não haja contradição (e com ela injustiças) na aplicação do Direito.

15. E a crítica não reside no fato de que a jurisprudência não possui poder de criar normas penais, até porque, como sabemos, ela possui poder para tal. O fato é que, na existência de tantas divergências sobre a aplicação do princípio (se é compatível com a reincidência, se pode ser aplicado aos crimes complexos, se deve respeitar limites monetários mínimos et coetera) se corre o risco de haver uma imensidão de diferentes decisões judiciais a respeito da mesma matéria, a depender do entendimento do aplicador do Direito.

16. A solução que se encontra para a presente problemática é que se respeite a natureza do princípio da insignificância, que é originário dos preceitos constitucionais, e o aplique sempre em conformidade com o que dita a Constituição. Assim atuando, afastar-se-ia, por exemplo, a presença do direito penal do autor (e se veria excluída a discussão em torno da reincidência e dos antecedentes). Afastar-se-ia a possibilidade de punir em excesso e discutir no Direito Penal fatos que não lesionam bens jurídicos (o que resolveria a discussão relativa aos crimes complexos, onde muitas vezes um dos bens tutelados não foi minimamente ferido).

17. O que traz a necessária segurança jurídica para uma legítima aplicação do princípio da insignificância é que não existem delitos irrelevantes: o irrelevante são os fatos. 


\section{REFERÊNCIAS BIBLIOGRÁFICAS}

ACKEL FILHO, Diomar. O princípio da insignificância no Direito Penal. Revista de Jurisprudência do Tribunal de Alçada de São Paulo. SP: TJSP, v. 94, p. 72-77, abr./jun. 1988.

ALMEIDA, Bruno Rotta. A discussão sobre a tutela penal de valores supraindividuais: ponderações a partir da teoria do bem jurídico-penal. Revista Magister de Direito Penal e Processual Penal. v. 5, n. 29, abr./mai., 2009.

ARAÚJO, Marcelo Cunha de. O princípio da insignificância e o argumento de autoridade: uma análise do recente acórdão do TJRS esculhambando o ministério público. Boletim do Instituto de Ciências Penais. v. 3, n. 49, ago.2004. p. 8-10.

ARMENTA DEU, Teresa. Criminalidad de bagatela y princípio de oportunidade. Alemania y España, Barcelona, PPU, 1991.

ARRUDA, Élcio. Insignificância: um princípio nada insignificante. Boletim IBCCRIM n ${ }^{\circ}$ 202, set.2009.

ASSIS, Jorge César de. O STF e o princípio da insignificância no crime militar de furto: significância de suas decisões. Direito Militar: Revista da Associação dos Magistrados das Justiças Militares Estaduais - AMAJME. v. 10, n. 64, mar./abr. 2007. p. 6-9.

BAJNO, Riccard. Contributo allo studio del bene giuridico nel diritto penale accessorio : l'ipotesi urbanismo-ambientale. Rivista Italiana di Diritto e Procedura Penale. v. 22, n. 1, jan./mar., 1979. 
BARATTA, Alessandro. Criminologia Crítica e Crítica ao Direito Penal. $2^{\mathrm{a}}$ ed. Rio de Janeiro: Freitas Bastos, 1999.

BARBERÁ, Gabriel Perez. Teoria Social de Sistemas y Derecho Penal de Minima Intervención. Revista de Derecho Penal, Buenos Aires, p. 133.

BARBOSA Jr, Salvador José. FRANZOI, Sandro Marcelo Paris. MORGADO, Nara Cibele Neves. Breves Anotações do Princípio da Insignificância. Revista IOB de Direito Penal e Processual Penal. Ano VII, no 41, p. 28-41, dez.jan.2007.

BATISTA, Nilo. Bases constitucionais do princípio da reserva legal. Revista de Direito Penal. n. 35, jan./jun., 1983.

. Introdução crítica ao direito penal brasileiro. Rio de Janeiro: Reva, 1990.

BECCARIA, Cesare. Dos delitos e das penas. SP:Martin Claret, 2000.

BECHARA, Ana Elisa Liberatore Silva. Da teoria do bem jurídico como critério de legitimidade do direito penal. Tese de Livre-Docência apresentada à Faculdade de Direito da USP, São Paulo, 2010.

BENETI, Sidnei Agostinho. A Constituição e o sistema penal. Revista Ajuris, Porto Alegre: Ajuris n. 156, 1992, p. 154-176.

BERISTAIN, Antonio. Derechos humanos y respuestas a la delinquência - Reflexiones desde uma ética de valores máximos. Revista Brasileira de Ciências Criminais, ano 10, n 40, SP: RT, out.dez., 2002.

BETTIOL, Giuseppe. Direito Penal, vol. I. São Paulo: RT.

BIANCHINI, Alice. Pressupostos materiais mínimos de tutela penal. São Paulo: TR, 2002. 
BITENCOURT, Cezar Roberto. MUÑOZ CONDE, Francisco. Teoria Geral do Delito. São Paulo: Saraiva, 2000.

BOTTINI, Pierpaolo Cruz. A confusa exegese do princípio da insignificância e sua aplicação pelo STF: análise estatística de julgados. Revista Brasileira de Ciências Criminais. n. 98, v. 20, 2012, p. 117-148.

O princípio da proporcionalidade na produção legislativa brasileira e seu controle judicial. Revista Brasileira de Ciências Criminais. v. 18, n. 85, jul./ago., 2010.

. Princípio da insignificância é um tema em construção. Revista Consultor Jurídico, publicado em 26.07.2011. Disponível em http://www.conjur.com.br/2011-jul26/direito-defesa-principio-insignificancia-tema-construcao.

- Princípio da insignificância no STF é uma novidade. Revista Consultor Jurídico, publicado em 06.09.2011. Disponível em http://www.conjur.com.br/2011-set06/direito-defesa-principio-insignificancia-stf-novidade.

(coord). O Princípio da Insignificância nos crimes contra o patrimônio e contra a ordem econômica: análise das decisões do Supremo Tribunal Federal. Pesquisa realizada na Universidade de São Paulo, jun. 2011. Disponível em http://www.conjur.com.br/2011-set-06/direito-defesa-principio-insignificancia-stfnovidade.

BRANDÃO, Cláudio. Introdução ao direito penal: análise do sistema penal à luz do princípio da legalidade. Rio de Janeiro: Forense, 2002.

BRUNO, Anibal. Direito Penal - parte geral. 3. ed. Rio de Janeiro: Forense, 1967.

BUCCI, Maria Paula Dallari. O princípio da razoabilidade em apoio à legalidade. Cadernos de Direito Constitucional e Ciência Política. v. 4, n. 16, jul./set., 1996. 
BUSTOS RAMIREZ, Juan. Manual de Derecho Penal, parte general., $3^{\text {a }}$ ed. Ariel: Barcelona, 1989.

CABETTE, Eduardo Luiz Santos, Informativo n. 489, in "Saberes jurisprudenciais 2012 - STF e STJ”. Bianchini, Alice (coord.), São Paulo: Saraiva, 2012.

CANCIO MELIÁ, Manuel. Los orígenes de la teoría de la adecuación social: teoría final de la acción e imputación objetiva. Bogotá: Universidad Externado de Colombia, 1998.

CARBONELl MATEU, Juan Carlos. Derecho Penal: Concepto y Principios Constitucionales. $3^{\text {a }}$ ed. Valencia: Tirant lo Blanch Alternativa, 1999.

CARVALHO, Márcia Dometila Lima de. Fundamentação Constitucional do Direito Penal. Fabris: Porto Alegre, 1992.

CARVALHO, Salo de. Pena e Garantias: uma leitura do garantismo de Luigi Ferrajoli no Brasil. Rio de Janeiro: Lumen Juris, 2001.

Reincidência e Antecedentes Criminais: Abordagem Crítica desde o marco garantista. Revista da Ajuris. Porto Alegre: Ajuris, 1999, vol. 76, p. 738-755.

CEREZO MIR, José. Derecho Penal - parte general. São Paulo: RT, 2007.

CERQUEIRA, Thales Tácito Pontes Luz de Pádua. O princípio bagatelar próprio e impróprio. Revista Magister de Direito Penal e Processual Penal. v. 1, n. 1, ago./set., 2004.

CERVINI, Raul. Os processos de descriminalização. 2 ed., SP:RT, 1994.

CHAVES, Cíntia Toledo Miranda. Breves considerações sobre direito penal mínimo e processo garantista. Pórtico jurídico, Juíz de Fora, v. 2, n. 2, p.124-143, 2000. 
COELHO, Edihermes Marques. O conceito de crime e a aplicação do princípio da insignificância. Cadernos de Estudos Jurídicos Contemporâneos. v. 1, n. 1, ago., 2001.

COMELLA, Vítor Ferreres. El principio de taxatividad em materia penl y el valor normativo de La jurisprudencia (uma perspectiva constitucuional), Madrid: Civitas, 2002.

CONSULICH, Federico. Materia penale e tutela dei beni giuridici nello spazio unitario europeo. Rivista Trimestrale di Diritto Penale Dell'Economia. v. 19, 1-2, jan./jun., 2006.

CORNEJO, Abel. Teoría de la insignificância. 1. ed. Buenos Aires : Ad-Hoc, 1997.

COSTA, José de Faria. Apontamentos para umas reflexões mínimas e tempestivas sobre o direito penal de hoje. Revista Brasileira de Ciências Criminais, São Paulo, v. 17, n. 81, p.36-47, nov./dez. 2009.

DALBORA, José Luis Guzmán. La insignificancia: especificación y reducción valorativas en el ámbito de lo injusto típico. Revista Brasileira de Ciências Criminais. São Paulo: n. 14, v. 4, p. 41-82, 1996.

D’ÁVILA, Fábio. SOUZA, Paulo Vinicius Sporleder de. Direito Penal Secundário. SP: RT, 2006.

DOTTI, René Ariel. Curso de Direito Penal. Rio de Janeiro: Forense, 2000.

ESTELLITA, Heloisa. LUZ, Yuri Corrêa da. Tribunais têm manejado equivocadamente a bagatela. Revista Consultor Jurídico, publicado em 21.08.2011. Disponível em http://www.conjur.com.br/2011-ago-21/equivocos-principio-insignificancia-ganhamfolego-tribunais.

FELDENS, Luciano. A Constituição penal. A dupla face da proporcionalidade no controle de normas penais, Porto Alegre: Livraria do Advogado, 2005. 
FELIPETO, Rogério. Princípio da insignificância e delito complexo. Boletim do Instituto de Ciências Penais-ICP, Belo Horizonte, v. 3, n. 32, p.3-4, dez. 2002.

FERNANDES, Luciana de Medeiros. Direito Penal Máximo ou intervenção mínima do Direito Penal? Breves lineamentos sobre a função do Direito Penal. Revista Brasileira de Ciências Criminais n ${ }^{\circ}$ 69. Nov.dez. 2007.

FERNANDEZ, Gonzalo D. Bien Jurídico y Sistema de Delito. Buenos Aires: Julio César Faira, 2004.

FERRAJOLI, Luigi. Derecho y razón, Madrid: Trotta, 2006.

FIANDACA, Giovanni. O bem jurídico como problema teórico e como critério de política criminal, Revista dos Tribunais, ano 89, v. 776, jun. 2000.

FIGUEIREDO, Ricardo Vergueiro. A pequena quantidade de entorpecente o princípio da insignificância e o artigo 290 do código penal militar. Revista da Associação dos Magistrados das Justiças Militares Estaduais - AMAJME. v. 8, n. 44, nov./dez., 2003.

FIGUEIREDO DIAS, Jorge de. Temas Básicos da Doutrina Penal. Coimbra: Coimbra, 2001.

FINKELSTEIN NAPPI, Juan L. Apuntes sobre lesividad e insignificancia a propósito del fallo Sepúlveda. Revista de Derecho Penal y Procesal Penal. n. 13, set., 2005.

FLORÊNCIO FILHO, Marco Aurélio. A aplicação dogmática dos princípios da insignificância no crime de roubo. Boletim IBCCRIM. v. 18, n. 217, dez., 2010.

GARCIA, Fco. Javier Álvarez Garcia. Sobre El principio de Legalidad. Valencia: Tirant lo Blanch, 2009.

GARCIA VITOR, Enrique Ulises. La insignificancia em el Derecho Penal. Los delitos de bagatela. Buenos Aires: Depalma, 2000. 
GARCÍA-PABLOS DE MOLINA, Antônio. Derecho Penal. Madrid, 1984.

GIACOMOLLI, Nereu José. Função garantista do princípio da legalidade. Revista IberoAmericana de Ciências Penais. v. 1, n. 0, mai./ago., 2000.

GOMES, Luiz Flávio. Princípio da Insignificância e outras excludentes de tipicidade. SP: RT, 2009.

. Criminalização e direito penal mínimo. Boletim IBCCRIM, São Paulo, n. 21, p.07, set. 1994.

Limites do "ius puniendi" e bases principiológicas do garantismo penal". In: Limites do "ius puniendi" e bases principiológicas do garantismo penal. Leituras complementares de processo penal. p. 49-62.

GOMES, Mariângela Gama de Magalhães. Bases para uma Teoria Geral da Parte Especial do Direito Penal. Tese de Livre-Docência apresentada à Faculdade de Direito da USP, São Paulo, 2012.

Direito Penal e Interpretação Jurisprudencial (do Princípio da Legalidade às Súmulas Vinculantes). SP: Atlas, 2008.

O princípio da proporcionalidade do Direito Penal. São Paulo: RT, 2003.

GONÇALVES, Henrique de Almeida Freire. Reincidência penal e princípio da insignificância. Disponível em www.ibccrim.org.br.

GRACIA MARTÍN, Luis. Fundamentos de dogmática penal: una introducción a la concepción finalista de la responsabilidad penal. Barcelona: Atelier, 2006. 
GRECO, Luís. Breves reflexões sobre os princípios da proteção de bens jurídicos e da subsidiariedade no direito penal. Revista Jurídica do Ministério Público de Mato Grosso. v. 2, n. 3, jul./dez., 2007.

TÓRTIMA, Fernanda Lara. O bem jurídico como limitação do poder estatal de incriminar? RJ: Lumen Juris, 2011.

GUIMARÃES, Daniel de Carvalho. A insignificância da lesão no delito de estelionato contra entidades públicas. Revista da Seção Judiciária do Rio de Janeiro. n. 29, dez., 2010.

GUIMARÃES, Isaac N. B. Sabbá. A intervenção mínima para um direito penal eficaz. Direito e Sociedade, Curitiba, v. 1, n. 1, p.165-193, set./dez. 2000.

HASSEMER, Winfried. Fundamentos del Derecho Penal, tradução de Francisco Muñoz Conde e Luis Arroyo Zapatero. Barcelona: Bosch.

JESCHECK, Hans-Heinrich. Tratado de Derecho penal. Granada: Colmares, 1993.

KATTAH, Marina. O princípio da insignificância e sua relação com o moderado direito penal do fato e com o funcionamento teleológico de Roxin. Revista Jurídica do Ministério Público do Estado de Minas Gerais. n. 8, jan./jul. 2007. p. 243-248.

LOPES, Maurício Antonio Ribeiro. Alternativas para o direito penal e o princípio da intervenção mínima. Revista dos Tribunais, Fascículos Penais, ano 87, v. 757, p. 402411, nov/1998.

Princípios políticos do direito penal. 2a ed. São Paulo: RT, 1999.

Princípio da insignificância no direito penal: análise à luz da Lei no 9.099/95. São Paulo: RT, 1997.

LUISI, Luiz. Os Princípios Constitucionais Penais. Porto Alegre: Fabris, 1991. 
O princípio da insignificância e o pretório excelso. Boletim IBCCRIM, v. 6, n. 63, fev. 1998.

LUZ, Yuri Corrêa da. Princípio da Insignificância em matéria penal: entre aceitação ampla e aplicação problemática. Revista de Direito $G V$ n $^{\circ}$ 15, jan.jun. 2012.

MACIEIRA, Ricardo Felipe R. Princípio da insignificância. Revista Brasileira de Ciências Criminais. v. 4, n. 15, jul./set.1996, p. 357-359.

MAGRO, Carlos Eduardo Pellegrini. Aplicação do princípio da bagatela nos crimes econômicos. Revista Criminal: ensaios sobre a atividade policial. v. 2, n. 5, out./dez., 2008.

MAHMOUD, Mohamad Ale Hasan. O princípio da insignificância e o crime continuado, sob uma angulação processual. Boletim IBCCRIM, v. 15, n. 182, jan. 2008. p. 14-15.

MARCHI JÚNIOR, Antônio de Padova. O princípio da insignificância e o crime de roubo. Boletim do Instituto de Ciências Penais, nº 13, p. 12.

MARINUCCI, Giorgio; DOLCINI, Emilio. Diritto Penale 'Minimo' e nuove forme di Criminalitá. Rivista Italiana di Diritto e Procedura Penale, Milano: Dott. A. Giufffre Editore, set. 1999.

MARQUES, Jader. Princípio da insignificância. Revista IOB de Direito Penal e Processual Penal. v. 7, n. 41, dez./jan. 2007.

Rejeição da denúncia, princípio da insignificância e extinção da punibilidade. Revista Síntese de Direito Penal e Processual Penal. v. 3, n. 18, p. 66-76, fev./mar. 2003.

MARQUES, José Frederico. Curso de direito penal - da infração penal. São Paulo: Saraiva, 1956. v. 2. 
MARTINEZ, Rosario de Vicente. El princípio de legalidad penal, Valencia: Tirant lo Blanch, 2004.

MARTÍNEZ, Santiago. Algunas cuestiones en torno a los principios de la legalidad y oportunidad. Cuadernos de Doctrina y Jurisprudencia Penal. v. 8, n. 14, dez., 2002.

MAURACH, Reinhart. Derecho Penal. Parte general. Atualizado por Heinz Zipf. Buenos Aires: Delpalma, 1994.

MENDES, Carlos Alberto Pires. O princípio da insignificância como excludente da tipicidade em casos de ínfima quantidade de droga apreendida - art. 16 lei n. 6.368/76. Boletim IBCCRIM n. 73, dez., 1998. p. 307-308.

MIR PUIG, Santiago. Derecho Penal. Parte General. 7. ed. Barcelona: Reppertor, 2006. Introducción a las bases del Derecho Penal. Concepto y método. Barcelona: Bosch, 1976.

MORAES, Jorge Luiz dos Santos. Princípio da insignificância. In FAYET JÚNIOR, Ney. A sociedade, a violência e o direito penal. p. 105-119.

MOREIRA, Alexandre Magno Fernandes. A subsidiariedade como baliza para a insignificância. Boletim do Instituto de Ciências Penais. v. 3, n. 54, jan./fev., 2005.

MOURA, Genney Randro Barros de. Breves anotações sobre o princípio da insignificância. Cidadania e Justiça. v. 4, n. 8, jul./dez., 2001.

MUÑOZ Conde, Francisco. Introducción al Derecho Penal. Barcelona: Bosch,

NAVARRETE, Miguel Polaino. Derecho Penal: parte general. Barcelona: Bosch, 1989.

NAHUM, Marco Antonio Rodriguez. Inexigibilidade de conduta diversa. Causa supralegal. Excludente de culpabilidade. São Paulo: RT, 2001. 
NOGUEIRA, Carolina Vilela de Faria Alves. A aplicabilidade do princípio da insignificância nos crimes de roubo. Boletim do Instituto de Ciências Penais. v. 7, n. 96, jun./jul., 2009.

NOGUEIRA, Fernando Célio de Brito. Os miseráveis e o princípio da insignificância.

Boletim IBCCRIM. v. 10, n. 116, jul. 2002.

NUCCI, Guilherme de Souza. A intervenção mínima no âmbito penal e o Estado democrático de direito. Carta Forense Disponível em www.cartaforense.com.br

OLIVEIRA, Luciano Moreira de; ALBUQUERQUE, Marcelo Schirmer. Aplicabilidade do princípio da insignificância aos crimes complexos. De Jure: Revista Jurídica do Ministério Público do Estado de Minas Gerais, Belo Horizonte, n. 4, p.59-66, jan./jun. 2002.

OTERO, Juan Manuel. Sobre el rol del derecho penal sustantivo en la búsqueda del derecho penal mínimo. Más Derecho? Revista de ciencias jurídicas. n. 2, 2001.

PALADINO, Carolina Freitas. Política criminal: direito penal mínimo x direito penal máximo. Revista da Seção Judiciária do Rio de Janeiro, Rio de Janeiro, n. 29, p.61-82, dez. 2010.

PALAZZO, Francesco Carlo. Valores constitucionais do direito penal. Porto Alegre: Fabris, 1989.

PALIERO, Carlos Enrico. Note sulla disciplina dei reati bagatellari, Revista Italiana de Diritto e Procedura Penale, Padova, Cedam, 1992.

PASCHOAL, Janaína Conceição. Constituição, Criminalização e Direito Penal Mínimo. São Paulo: RT, 2003.

PELUSO, Vinicius de Toledo Piza. A objetividade do princípio da insignificância. Boletim IBCCRIM. v. 9, n. 109, dez., 2001. 
PEREIRA, Carlos Frederico. O conceito de bem jurídico e o princípio da insignificância. Revista do Ministério Público Militar. Brasília: MPM, nº 13, p. 45-50, 1991.

PRADO, Luiz Regis. Bem Jurídico-Penal e Constituição. $3^{\text {a }}$ ed. São Paulo: RT, 2003. Elementos de Direito Penal. São Paulo: Revista dos Tribunais, 2005.

PRESTES, Cássio Vinicius D. C. V. Lazzari. O Princípio da insignificância como causa excludente da tipicidade no Direito Penal. SP: Memória Jurídica Editora, 2003.

QUEIROZ, Paulo de Souza. Direito penal: parte geral. 6. ed. Rio de Janeiro: Lumen Juris, 2010.

Do caráter subsidiário do Direito Penal: lineamentos para um Direito Penal Mínimo. Belo Horizonte: Del Rey, 1998.

- Princípio da insignificância e maus antecedentes. Disponível no site http://pauloqueiroz.net/principio-da-insignificancia-e-maus-antecedentes.

RANGEL, Francisco Roberto. Princípio da insignificância como causa da exclusão da responsabilidade. Cidadania e Justiça. v. 1, n. 1, jan./jul. 1998.

REALE JÚNIOR, Miguel. Instituições de Direito Penal. RJ: Forense, 2009. Teoria do Delito. 2. Ed. São Paulo: RT, 2000.

REIS, André Wagner Melgaço. A aplicação do direito da insignificância no crime de descaminho à luz da jurisprudência do STJ e do STF. Del Rey Jurídica. v. 9, n. 18, ago./dez., 2007.

REIS, Whith Martins dos. O estado democrático de direito: importância do princípio da legalidade. Cidadania e Justiça. v. 6, n. 11, jan./jun., 2003. 
RIBEIRO, Julio Dalton. Princípio da insignificância e sua aplicabilidade no delito de contrabando e descaminho. Revista Brasileira de Ciências Criminais. v. 16, n. 73, jul./ago. 2008.

ROBERTI, Maura. A intervenção mínima como princípio no Direito Penal Brasileiro. Fabris: Porto Alegre, 2001.

ROCHA, Eduardo Carraro. Tóxico : porte de substância x princípio da insignificância. Revista Síntese de Direito Penal e Processual Penal. v. 3, n. 17, dez./jan. 2003.

ROXIN, Claus. Iniciación al derecho penal de hoy. Sevilla, Ediciones Universidad de Sevilla, 1981.

A proteção de bens jurídicos como função do direito penal. Porto Alegre: Livraria do Advogado, 2009.

Politica criminal y sistema de derecho penal. Barcelona, Bosch, 1972.

RUDDOLPHI, Hans Joachim. Los diferentes aspectos del concepto de bien jurídico, Nuevo pensamento penal, 1975.

SALVADOR NETTO, Alamiro Velludo. Finalidades da pena - conceito material de delito e sistema penal integral. São Paulo: Quartier Latin, 2009.

SANGUINÉ, Odone. Observações sobre o princípio da insignificância. Fascículos de Ciências Penais. v. 3, n. 1, p. 36-50, jan./mar. 1990.

SANTOS, André Leonardo Copetti. Da intervenção mínima à intervenção minimamente necessária para a realização do estado democrático de direito nos países de modernidade tardia. Revista do Instituto de Hermenêutica Jurídica, Porto Alegre, v. 1, n. 1, 2003.

SANTOS, Cláudia Maria Cruz. Direito penal mínimo e processo penal. Boletim IBCCRIM, São Paulo, v. 15, n. 179, p.13, out. 2007. 
SANTOS, Juarez Cirino dos. A moderna teoria do fato punível. Rio de Janeiro: Freitas Bastos, 2000.

SANTOS, Lycurgo de Castro. Princípio da intervenção mínima do direito penal e crimes de menor potencial ofensivo - Lei 9.099/95. In Revista Justiça e Democracia. São Paulo: RT, n. 1, p. 198-206, 1996, p. 123.

SANTOS, Thiago Pedro Pagliuca dos. A aplicação do princípio da insignificância ao roubo. Boletim IBCCRIM. v. 18, n. 218, jan., 2011.

SILVA, Ivan Luiz da. Princípio da insignificância no Direito Penal. Curitiba: Juruá, 2011.

SILVA, Renato Lopes Gomes da. Princípio da insignificância e os atos administrativos. A força policial: órgão de informação e doutrina da instituição policial militar. v. 63 , n. 63, jul./set. 2009.

SILVA SÁNCHEZ, Jesús María. A expansão do direito penal: aspectos da política criminal nas sociedades pós-industriais. São Paulo: Revista dos Tribunais, 2002.

SIQUEIRA, Geraldo Batista de. Ação penal. Inépcia material, rejeição. Princípio da insignificância ou de bagatela. Revista IOB de Direito Penal e Processual Penal. v. 10, n. 58, out./nov., 2009.

SIRVINSKAS, Luis Paulo. Ainda sobre normas penais em branco e bem jurídico tutelado nos crimes ambientais. Boletim IBCCRIM. n. 73, dez., 1998.

SMANIO, Gianpaolo Poggio. A tutela penal constitucional. Revista Brasileira de Ciências Criminais. v. 10, n. 39, jul./set., 2002.

SOLER, Sebastian. Direito Penal Argentino. Buenos Aires: TEA, 1951. 
SOUZA, Fernando Antônio C. Alves de. Princípio da insignificância: os vetores (critérios) estabelecidos pelo STF para a aplicação na visão de Claus Roxin. Revista Magister de Direito Penal e Processual Penal. v. 6, n. 31, ago./set. 2009.

STOCO, Rui. Princípio da insignificância nos crimes contra a ordem tributária. Boletim do Instituto Manoel Pedro Pimentel. v. 4, n. 18, out./dez. 2001.

TAVARES, Juarez. Teoria do injusto penal. 2. ed. Belo Horizonte: Del Rey, 2002. Critérios de seleção de crimes e cominação de pena. In Revista Brasileira de Ciências Criminais. No especial de lançamento, dez. 1992.

TOLEDO, Francisco de Assis. Princípios básicos de Direito Penal. São Paulo: Saraiva, 2000.

VICO MAÑAS, Carlos. O princípio da insignificância como excludente da tipicidade no direito penal. São Paulo: Saraiva, 1994.

Princípio da insignificância: excludente da tipicidade ou da ilicitude? In: ESCRITOS em homenagem a Alberto Silva Franco. São Paulo: Revista dos Tribunais, 2003, p.143-150.

VIRGOLINI, Julio E. S. Las lesiones levísimas: un caso de atipicidad por insignificancia. Doctrina Penal: Teoría y prática en las ciencias penales, Buenos Aires, v. 8, 29/32, p.119129, 1985.

VITOR, Enrique Ulises Garcia. La insignificancia em el Derecho Penal. Los delitos de bagatela. Buenos Aires: Depalma, 2000.

ZAFFARONI, Raul Eugenio. Manual de Direito Penal. SP: RT, 2009.

Sistemas penales e derechos humanos em America Latina. Buenos Aires: Depalma, 1986. 
ZIPF, Heinz. "Introducción a la politica criminal". Madrid: Revista de Derecho Privado/Editoriales de Derecho Reunidas, 1979.

WELZEL, Hans. "Derecho Penal aleman, Parte General", 11. ed., Santiago de Chile: Ed. Jurídica de Chile, 1970. 